\title{
De taken van de huisarts : resultaten van een taakanalyse in 91 huisart[s]praktijken
}

Citation for published version (APA):

van Zutphen, W. M. (1984). De taken van de huisarts : resultaten van een taakanalyse in 91 huisart[s]praktijken. [Doctoral Thesis, Maastricht University]. Rijksuniversiteit Limburg. https://doi.org/10.26481/dis.19841213wz

Document status and date:

Published: 01/01/1984

DOI:

10.26481/dis.19841213wz

Document Version:

Publisher's PDF, also known as Version of record

\section{Please check the document version of this publication:}

- A submitted manuscript is the version of the article upon submission and before peer-review. There can be important differences between the submitted version and the official published version of record.

People interested in the research are advised to contact the author for the final version of the publication, or visit the DOI to the publisher's website.

- The final author version and the galley proof are versions of the publication after peer review.

- The final published version features the final layout of the paper including the volume, issue and page numbers.

Link to publication

\footnotetext{
General rights rights.

- You may freely distribute the URL identifying the publication in the public portal. please follow below link for the End User Agreement:

www.umlib.nl/taverne-license

Take down policy

If you believe that this document breaches copyright please contact us at:

repository@maastrichtuniversity.nl

providing details and we will investigate your claim.
}

Copyright and moral rights for the publications made accessible in the public portal are retained by the authors and/or other copyright owners and it is a condition of accessing publications that users recognise and abide by the legal requirements associated with these

- Users may download and print one copy of any publication from the public portal for the purpose of private study or research.

- You may not further distribute the material or use it for any profit-making activity or commercial gain

If the publication is distributed under the terms of Article $25 \mathrm{fa}$ of the Dutch Copyright Act, indicated by the "Taverne" license above, 
De taken van de huisarts.

Resultaten van een taakanalyse

in 91 huisartpraktijken.

\section{Proefschrift}

ter verkrijging van de graad van doctor in de geneeskunde an de Rijksunfversteit Limburg te Maastricht op gezag van de Rector Magnificus Prof. Dr H.C. Hemker, volgens het besluit van het College van Dekanen in het openbaar te verdedigen op donderdag 13 december 1984 in de aula van de unfversiteit des namiddags om vier uur precies door

W11helmus Marinus van Zutphen geboren te Utrecht 
Promotores: Prof, Dr W. Brouwer

Prof. Dr H. Philipsen

Referenten Prof. Dr F.J.A. Huygen (Nijmegen)

Prof. Dr F.A. Vorst (Maastricht)

Tekstverwerking: I.Slegelaer-Gerardu

Oms $1 \mathrm{ag}$

: H.W. van Zutphen

Druk

- dink reprogratie 
LHV = Landel1jke Huisartsen Verenlging

KNMG = Konlnklijke Nederlandse Maatschappij ter bevordering van de Geneeskunst

NHG = Nederlands Hulsartsen Genootschap

NHI = Nederlands Huisartsen Instituut

UUHI = Utrechts Universitair Hulsartsen Instituut

GAK = Gemeenschappelijk Administratie Kantoor

GMD = Gemeenschappe11jke Medische Dlenst

DGD = Districts Geneeskundige Dienst

HRC = Huisartsen Registratie Commissie

$\mathrm{HAO}=$ Huisartsople1der

CB = Consultatie Bureau voor Zulgelingen en Kleuters

CBS = Centraal Bureau voor de Statistlek

GOR = Gedragsobservatie-registrator

PGO = Periodiek geneeskundig onderzoek

GVO = Gezondheldsvoorlichting en -opvoeding 
Inhoud.

Afkortingen III

Voorwoord VII

1. Inleiding.

1.1. Voorgeschiedenis en aanleiding tot het onderzoek.

1.2. Vraagstelling van het onderzoek.

1.3. De indeling van de rapportage.

2. De 1iteratuurverkenning met betrekking tot de probleemstelling.

2.1. Inleiding.

2.2. De taken van de huisarts.

2.3. De omschrijving van de taken van de huisarts.

2.4. De factoren, die met de taakuitoefening van de hulsarts samenhangen.

3. De observatie-methode.

3.1. Inleiding.

3.2.1. De theoretische uitgangspunten voor de methode van observatie.

3.2.2. Vormen van observaties.

3.2.3. Soorten van observatie instrumenten.

32.4 . De achtergrond voor het opstellen van een warnemingssysteem, met name een categorleënsysteem.

3.2.5. Selectle van waarnemingselementen om classificeren van het waargenomene mogel1jk te maken.

3.3.1. Het ontwerpen van een observatieInst rument.

$3 \cdot 3.2$. Soorten van waarnemingselementen.

3.3.3. Factoren, die de waarneming beinvioeden.

3.3.5. De invloed van de observator. 
3.3.6. De technische hulpmiddelen bij de observatie.

3.4. De observatie-categorieên.

3.5. De geldigheld en betrouwbaarheid van de taakmeting.

3.5.1. De geldigheld.

3.5.2. De betrouwbarheid. 59

3.6. De representativiteit van de observaties. 60

3.7. De toepassing van het meetinstrument. 61

3.8. Samenvatting.

4. De opzet en de uitvoering van het onderzoek.

4.1. Inleiding.

4.2 .

De methode van onderzoek.

4.3.

De verzamelde gegevens.

4.4 .

De wijze van gegevensverzamellng.

4.5 .

De observatiemethode.

4.6 .

De meetinstrumenten.

4.6.1. De observaties.

4.6.2. De taakperceptie-meting.

4.7 .

De steekproeven.

74

4.7.1. "Klelne" steekproef.

74

4.7.2. "Grote" steekproef.

75

4.7.3. Representativiteit.

5. De beschrijuing van de varlabelen: meetresultaten.

5.1. Inleiding.

5.2. De tijdvariabelen.

5.3 .

De verklarende variabelen.

5.3.1. Het verzamelen van gegevens.

5.3.2. Overz1cht van de gemiddelde warden en standaard-deviaties van de verklarende varlabelen. 
6. De taken van de hulsarts.

6.1. Inleiding.

6.2. De factoranalyse.

6.3. Bespreking van de resultaten.

6.4. De vergelljking tussen de zes factoren en het Basis-Takenpakket.

7. De regressie-analyse.

7.1. Inleiding.

7.2. De regressie analyse.

7.3. Resultaten van de regressie analyse.

7.3.1. Varlabele 1: de curatieve zorg.

7.3.2. Varlabele 2 : samenwerking en onderwijs geven.

7.3.3. Variabele 3: consultatle en nascholing.

7.3.4. Vartabele 4: secundalre preventie.

7.3.5. Variabele 5: primaire preventie.

7.3.6. Variabele 6 : gespreksvoering

8. Samenvatting en bespreking van de resultaten.

8.1. Inleiding.

8.2 .

Het observatie-instrument.

8.3 .

De perceptiemeting.

8.4 .

De aard en het karakter van het

8.5. onderzoek en de beperkingen ervan.

Summary.

Literatuur

B1jlagen 
Voorwoord.

Door de sterke aandacht voor de plaats, de functie en de taken van de huisarts is er behoefte ontstaan aan ciffermatige onderbouwing van de functle van de hulsarts in de gezondheidszorg. Die behoefte is de directe aanleiding geweest om aan de Rijks Unlversitelt Limburg in 1977 daar een onderzoek naar te doen. Dit proefschrift is voortgekomen wit het facultaire onderzoeksproject "Onderzoek functieanalyse huisartsen". dat onderlelding stond van Dr J. Boots van de capaciteitsgroep Medische Socilologie. In dit project was het mijn taak om er in de eerste plaats voor te zorgen, dat er een observatie instrument kwam om huisartsen in hun dagelijkse bezigheden te observeren en daarmee een tifdstudie ult te voeren. Toen ook een meting van de taakperceptie noodzakelijk bleek, heb ik in de tweede plaats meegewerkt aan het het ontwlkkelen van een daarvoor geschikte vragen11jst. De ultwoering van het veldwerk en de gegevensverwerking is onze gezamelijke verantwoordelijkheld geweest. De door Boots voor zijn onderzoek geformuleerde doelstelling was het geven van een beschrijuing van de rol van de huisarts in de gezondheidszorg aan de hand van de te meten tijdsbesteding aan de onderscheiden functies van de huisarts. Het resultaat daarvan heeft hij beschreven in $z i j n$ proefschrift: Het werk van de huisarts (Boots, 1983).

Het verzamelde gegevensmateriaal overziende werd mij in 1980 duidelijk, dat er nog een tweede analyse mogelijk was, namelijk gericht op de vraag welke taken de huisarts met zijn dagelijkse werkzaamheden feitelijk tracht te verullen. Van die analyse wordt in dit proefschrift verslag gedaan. Hoewel de onderzoekers dus in de analyse leder huns weegs zijn gegaan, zijn beide onderzoeken nauw met elkaar verweven. De onderzoeksopzet is gelijk, dezelfde meet-instrumenten zijn gebrulkt en er is ook gebruik gemaakt van nagenoeg de zelfde variabelen.

Dank ben ik verschuldigd aan:

Jan Boots voor de samenwerking en zijn hulp. Prof. Dr W. Brouwer voor zijn hulp bij het tot stand brengen van een goede opbouw en leesbaarheld van het verslag. Prof. Dr H. Philipsen voor zijn methodologische en praktische aanwijzingen.

Prof. Dr F. Huygen en Prof. Dr F. Vorst voor hun deskundig 
commentaar, dat $z 1 j$ bovendien op korte termijn hebben w11len leveren.

Henk Lebens en Milchel Janssen voor hun assistentle bij het gebruik van de computer.

Ruud Halfens voor zljn aanwijzingen bij de factoranalyse. Jacques Relners voor zijn hulp bij de voorbereiding en de ultvoering van de schriftelijke enquête.

Mieke van de Loo voor het vele typewerk, het opmaken van de literatuurlijst en voor de morele steun, die ik van haar en van onze zoon Maurice mocht ontvangen. Z1j delen geheel in de eer.

Ine Slegelaer die met het op tekstverwerker zetten van het manuscript heel wat te doorstaan heeft gehad.

Bep Köhlen, Marlies In de Braekt, Jimy Tatipata en Marianne Bruljstens voor hun adviezen en hulp bij het verwerken van de tekst.

Marga Doyle voor alle secretarlële hulp bif het project en de correctle van de summary.

MIjn broer Harry van Zutphen, die het omslag heeft gemaakt. Ben Meerstad en de zijnen voor de correcte verzorging van het drukwerk.

Alle hulsartsen, die aan dit project hebben meegewerkt en zich een week lang hebben laten observeren.

De observatoren voor hun inzet en volharding. Allen, die op enigerlei wijze het onderzoek hebben mogelijk gemaakt. 
Hoofdstuk 1. Inlelding.

\subsection{Voorgeschiedenis en aanleiding tot het onderzoek.}

Met het verschijnen van de Structuurnota Gezondheidszorg (1974) brak een nieuw tijdperk voor de huisartsgeneeskunde in Nederland aan. In deze nota maakte de overheid duidelijk dat ter beheersing van de kosten en ter verhoging van de doeltreffendheid van het systeem van de gezondheldszorg,

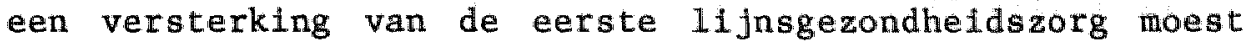
plaatsvinden.

Gedurende een periode van exponentiële groei van de specialistische geneeskunde enerzijds en van hoogconjunctuur anderzijds had men nauwelijks aandacht gehad voor de rol van de eerste $11 \mathrm{jn}$ en van de huisartsen. Door de hoogconjunctuur had de huisarts in economisch opzicht overigens niet te klagen. Dankzij de commissie Van de Ven waren bij de verzekeraars en de overheld gunstige voorwaarden voor de honorering bedongen en verkregen. Jonge artsen pas van de collegebanken, konden hun loopbaan als huisarts beginnen met een honorarium volgens BBRA-schaal 151 max. De huisartsen waren trendvolgers geworden. Er was bovendien een relatief tekort aan huisartsen. Er waren rulme mogelijkheden om praktijken over te nemen. De hoge goodwillsommen en de dure woon- en praktijkhuizen vormden geen bezwaar. Door de grote financiële zekerheid waren de geldschieters bereid soms meer dan $100 \%$ te financleren.

Maar, zoals gezegd, de gezondheidszorg werd te duur, vooral door de onevenredige groel van de 1 thtramurale zorg, een proces dat ook na 1978 nog niet echt is omgebogen, zoals blijkt uit onderstaande tabel:

Kostenverhouding in percentages van de totale kosten binnen de gezondheldszorg.

$\begin{array}{lllll}1963 & 1968 & 1973 & 1978 & 1982\end{array}$

$\begin{array}{lrrrrr}\text { Extramurale zorg } & 40 & 35 & 30 & 29 & 31 \\ \text { Intramurale zorg } & 45 & 55 & 62 & 65 & 64 \\ \text { Overige } & \frac{15}{100} & \frac{10}{100} & \frac{8}{100} & \frac{6}{100} & \frac{5}{100}\end{array}$


(ontleend aan gegevens van de Centrale Raad voor de Volksgezondheid. Met betrekking tot $1978 \mathrm{e.v}$. ontleend aan het Finaneleel overzlcht).

De Structuurnota bracht in de eerste plats ordening in de organisatorische situatie van de gezondheldszorg. De echelonering verenigde op logische wijze de bij elkaar horende disciplines tot functionele eenheden. In de tweede plaats zou het eerste echelon, waaronder de huisartsgeneeskunde valt, versterkt moeten worden. Het beleid werd gericht op thuiszorg en het minder doorverwijzen van patienten naar de veel duurdere specialistische zorg. Hoe dit precies moest gebeuren was voorlopig nog onbekend. Er werd aan versch11lende matregelen gedacht, onder andere aan intensivering van de samenwerking en beschikbaar stellen van diagnostische faciliteiten aan de huisarts. Uiteraard betekende dit een taakverzwaring voor de huisarts, die toch al zo druk bezet was. De gemiddelde praktijkgrootte bedroeg in 1972 ruim 3000 zielen.

Daar kwam nog bij dat de toenmalige links-midden coalitieregering moelte had met de daarmee gepaard gaande hoge inkomens van de hulsartsen, overigens ook met die van de speclalisten. In politiek opzlcht werden de hoge inkomens van de huisartsen een ongunstige factor geacht voor de ontwikkeling van de interdisciplinaire samenwerking in het eerste echelon. Immers in de beoogde samenwerkingsverbanden zou de hulsarts degene zijn met het hoogste inkomen. Die ongelijkheld zou, voortvloelende uit een politiek van spreiding van kennls Inkomen en macht moeten verminderen ten gunste van de andere werkers. De betwisting van de financielle positie En de verwachte taakverzwaring veroorzaakten in de gelederen van de georganiseerde hulsartsen een gevoel van malalse depressie en verlaming. Te welnig zag men de grote mogelijkheden die in feite geboden werden om, gesteund door ảe overheld, de centrale positie van de hulsarts in de gezondheldszorg te speciffceren. In de jaren 1972-1975 hebben betrekkelijk veel huisartsen de praktifk verlaten (NHI-rapport, 1977) deels ow zich alsnog te speclaliseren, maar vooral om soctaal-geneeskundige of ambtenaar-arts te worden. De toestand van verlaming, desillusie en onrust zijn als een crisis te beschouwen; evenwel een crisis van een ander karakter dan die in de vijftiger faren. In de huidige situatie lijkt mij het vraagstuk van de identiteit van de 
huisarts centraal te staan. De hulsarts zal nu moeten laten zien op welke wijze hij bijwoorbeeld de medicallserling kan terugdringen en de thuiszorg kan bevorderen.

Laten we teruggaan naar de crisis in de vijftiger jaren om aan de hand van een schets van de historische ontwikkeling een inzicht te krijgen in de huidige problematiek. Na de tweede wereldoorlog begon al snel een ingrijpende technologische ontwikkeling in de geneeskunde en de gezondheidszorg op gang te komen. De zorg kon in technisch opzicht sterk worden verbeterd, zowel in diagnostische als in therapeutische zin. Het gevolg was dat vooral het aantal speciallsmen zich sterk heeft ultgebreid. Daarbij kwam dat de overheid en het particulier initiatief een aantal instanties hebben gecreëerd, die vooral in de stad de huisarts een deel van zijn werkzaamheden hebben afgenomen. Zo gingen de Gemeente11jke Geneeskundige en Gezondheids Diensten (thans de Districts Geneeskundige Diensten) de eerste hulp bij verkeersongevallen overnemen. De zorg voor schoolkinderen en voor werkenden in bedrijven kwam in handen van school-, respectievelijk bedriffsartsen. Hiertegen ontstonden individuele, vaak emotionele uitingen van onbehagen en agressie. De zuigkracht, die er van de specialistische geneeskunde uitging, had tot gevolg, dat de huisarts zich als een verkeersagent voelde tegenover een stroom van verwijzingen naar de specialisten.

Door de ontdekking van de chemotherapeutica en de antibiotica waren de infectieziekten inmiddels goed behandelbaar geworden. Dit feit èn de ultgebreidere preventieve zorg voor het kind hebben een aantal sterfte-oorzaken teruggedrongen. Het aantal oudere mensen nam onder andere hierdoor relatief en absoluut toe en de gemiddelde leeftijd van de bevolking stijgt van jaar tot jaar. Parallel hieraan verschoof het zwaartepunt van de aangeboden pathologle gaandeweg naar de oudere bevolkingsgroepen en daarmee naar de slijtage- en ouderdomskwalen (degeneratieve aandoeningen, tumoren, chronische ziekten, invaliditeit).

Sinds de oorlog is mede als gevolg van de invoertng van het ziekenfondssysteem, wardoor het grootste deel van de bevolking lid was geworden van het zlekenfonds, het aantal aan de huisarts aangeboden aandoenlngen fors gestegen. De consultatiefrequentle nam toe, vooral voor zlekten veroorzaakt door aspecifleke factoren. Zo stelde Ruhe (1957) in zijn praktijk vast, dat in de loop der jaren tussen 1938 en 
1954 het aantal ter behandeling gekomen aandoeningen vrijwel verdubbelde en dat het aantal consulten op het spreekuur verdrlevoudigde. Er vond een accentverschulving plaats van somatische naar psychische en milleuproblematiek en van de klassleke ernstig zleke patiënt naar de in geringe mate zleke of quas1 gezonde "onaangepaste" mens met gezins-, arbeids- en levensproblematiek. De medische problematiek raakte meer en meer gecompliceerd door psychosociale dimensies (Hornstra, 1950).

Door die accentwerschuiving in $21 \mathrm{jn}$ werk zag de hulsarts zich geplatit tegenover een problematiek, waartegen hij zich machteloos voelde. Hij was er niet voor opgeleid om deze problematiek te verwerken. Zo ontbrak het hem aan voldoende en adequate gespreks - en onderzoekstechniek en aan methodieken voor behandeling. Hij had bovendien onvoldoende kennis ten anzien van de invloeden van het milieu op de gezondheld en had weinig ervaring en vaardigheden om samen te werken met het maatschappelijk werk en soclaal-medische instanties. Het was onvermijdelijk dat de huisarts zich in deze omstandigheden onzeker ging voelen. Er heerste defaitisme ten aanzien van status en toekomst. Enerzijds werden taken overgenomen door anderen, zoals specialisten en medisch( ambtelijke) instanties en kreeg hij anderzljds taken toegeschoven waar hij onvoldoende deskundigheid voor bezat. Hij rakt in een concurrentiële crisis; een crisis, waarbij vooral de waardering van zijn hulpverlening en zijn medische status als huisarts in het geding was.

Buma (1959) zag als belangrijkste factor voor het welslagen van een poging tot herstel van de status het zelfbewustzijn van de hulsarts. Dat zelfbewustzijn zou systematisch moeten worden hersteld door krttsch onderzoek naar zijn functies en taken, alsmede door een degelljke technlsche onderbouwing daarvan.

"Er zal een elnde moeten komen aan de toestand waarbij de hulsarts de voetveeg is van velen en zijn arbeldsterrein de vergaarbak warheen datgene wordt afgeschoven warmee de matschappij geen raad weet". (Buma, 1959, p. 40).

Dat zou berelkt moeten worden door de verantwoordelijkheden van de huisarts en de wijze warop hij hieraan vorm en inhoud zal geven, vast te leggen in een functie en taakomschr1jving.

Dat is gebeurd op de $\mathrm{zg}$. Woudschoten-conferentie op 23 en 24 Januar1 1959, nadat in 1956 eerst het Nederlandse Huis- 
artsen Genootschap was opgericht De fundamentele doelstelling van dit genootschap is het op een hoger niveau brengen van de huisartsgeneeskunde door middel van studie, onderzoek en nascholing.

De op de Woudschoten-conferentie geformuleerde en nog steeds geldig geachte omschrijving van de functie van de huisarts luidt:

"Het Nederlands Huisartsen Genootschap ziet de funktie van de huisarts als het aanvaarden van de verantwoordelijkheid voor een continue, integrale en persoonlijke zorg voor de gezondheid van de $z i c h$ an hem toevertrouwende individuele mensen en gezinnen. Het ziet die zorg als het opheffen, in hun uitwerking beperken en waar mogelijk voorkomen van stoornissen in de individuele of gezinsgezondheld (curatief, revaliderend, preventief)" (Woudschotenrapport, 1959).

De uit deze functie-omschrijving voortvloeiende strikt medische taken van de hulsarts zijn als volgt omschreven: (Woudschotenrapport pag. 1 en 2).

1. Eerste hulp, ook voor psychische traumata.

2. Somatisch onderzoek.

3. Psychisch en sociaal onderzoek, warbij de beheersing van goede gespreks- en anamnese-techniek essentiëel is.

4. Registratie en beheer van alle medische gegevens.

5. Differentiatie van patiënten in twee groepen, namelijk in een groep, warvan de behandeling binnen de dage$1 i j k s e$ routine valt en een groep, dle afzonderlijk behandeling vraagt door het gecompliceerde van haar bijzondere problematiek.

6. Behandelen van wat voor hem behandelbaar 18.

7. Ad hoc en tijdelijk delegeren naar medische en andere deskundigen, waarbij zijn medeverantwoordelijkheid blijft bestaan.

8. In overleg met behandelende en adviserende medische specialisten en andere deskundigen opstellen van een nazorgplan en zorg voor de uitvoering daarvan.

9. Integratie en coördinatie van de zorg voor de zleke, invalide en onaangepaste mensen door een goede samenwerking met andere deskundigen, war nodig in teamverband.

10. Bijdragen tot preventie. 
11. Bljdragen an de gezondheldsvoorlichting en -opvoeding.

12. Bl1fven werken aan elgen deskundigheid en vorming, met een open oog voor eligen mogelijkheden en grenzen.

Aan de hand van deze onderscheiden deeltaken moest een beleld voor de bevordering van hulsartsgeneeskunde worden opgesteld. Dat beleid ging zich richten op de volgende zaken. (Woudschotenrapport, pag. 2 en 3).

- Het ontwikkelen van gesprekstechniek, intercollegiaa1 en in de arts-patiënt relatie.

- Studie van persoonlijkheidsstructuren.

Studie van milleu-invloeden op de mens.

- Studie van veranderingen in het matschappijbeeld.

- Studie van de elgen mogelijkheden en grenzen van de hulsartsgeneeskunde.

- Het bewaken van hetgeen voor de huisarts behouden moet biljuen.

- Voorlichting over spoedeisende gevallen in de huisartspraktijk.

- Het ontwikkelen van een efficiënte praktijkvoering en een uniforme registratie techniek van medische gegevens.

- Het invoeren van afspraakspreekuren.

- Het opzetten van een systeem van nascholing.

- Studie naar de konsekwenties van de gedeelde verantwoordelijkheld in de patiëntenzorg met de specialisten en andere deskundigen.

- Het bevorderen van de centrale plaats van de huisarts In de zorg om de patiënt; de huisarts als coördinator. - Bestudering van de positie van de huisarts in de algemene preventie en de mogelijkheden van nazorg.

De samenbundellng van krachten die aanleiding heeft gegeven tot de oprichting van het NHG en tot het houden van de Woudschoten-conferentle heeft Buma als een revell gekarakteriseerd. Dit revell kreeg gestalte in de bovengenoemde beleidswoornemens en heeft in de zestiger jaren aan de hulsartsgeneeskunde ongetwiffeld een impuls gegeven. Het NHG begon aandacht te besteden aan praktijkvoering, prakt1jkinrichting (o.a. binnenhulsarchitectuur voor de prakt1jkruimte), registratiesystemen (groene kaart, zwangerschapskaart, kaart voor pilcontrôle), instrumentarium, in- 
houd van visite- en verlostas, laboratorium, sterilisatie van instrumenten, etc.

Men ging werken met speciaal opgeleide doktersassistentes (Ten Cate, 1963), warvoor in 1970 zelfs een normatieve taakomschrijving is geformuleerd. De efficiency in de praktijkvoering werd bestudeerd en middelen ter verhoging ervan werden aangedragen. (Saan, 1967). Er kwamen afspraakspreekuren en beter georganiseerde weekelnd- en avonddienstregelingen. Een verdere uitbouw van deze op rationalisatie gerichte activitelten werd op professionele basis overgenomen en voortgezet door het NHI dat in 1964 is opgericht; een duidelijke stap naar een professionele fundering van de huisartsgeneeskunde. Als voorbeeld hlervan kunnen worden genoemd de voorlichtingscursussen voor aanstaande huisartsen en de Beroepsopleiding met de oprichting van de Huisarts Registratie Commissie in 1973, naar analogie van de specialistenopleiding.

De nascholing kwam tot ontwikkeling. De gesprekstechniek werd ter hand genomen en er kwamen Balintgroepen. Er werden op landelijk nfveau (in samenwerking met de Boerhaave Stichting en de Van Hoytema Stichting) en op reglonaal niveau (naar het model van de Warffum-cursussen) nascholingsactiviteiten georganiseerd. Er werd een begin gemaakt met de academische fundering van de huisartsgeneeskunde. die zijn bezegeling heeft gekregen in de oprichting van leerstoelen aan de universiteiten.

Niet alleen in weekeinddiensten werd de samenwerking bevorderd. Men stimuleerde de ontwikkeling naar groepspraktijken en vooral naar gezondheldscentra, waraan de overheld steun gaf met een subsidieregeling. Daarmee is ook een aanzet gegeven tot interdisciplinaire samenwerking met het maatschappelijk werk, de wijkverpleging en in sommige gevallen met psychologen.

ook het onderzoek door huisartsen werd geëntameerd. Vanult de doelstelling: "het bewaken van hetgeen voor de hulsarts behouden moet blijven" en "de positie van de hulsarts in de algemene preventie en nazorg" is vooral het werk van Van Den Dool (1970) te noemen, die daarmee de grondslag heeft gelegd voor het toepassen van anticipatie en surveillance. Een voorbeeld van een studie naar de konsekwentles van de gedeelde verantwoordelijkheld van de patiëntenzorg met de specialisten en andere deskundigen is het werk van De Melker (1973). Belangrijke voorbeelden van onderzoeken naar 
morbiditedt en epidemiologie zijn die van ollemans (1969) en Sm1t (1974).

Ruwweg zou men kunnen zeggen, dat de activiteiten en de onderzoeken, niet zonder succes overigens, gericht waren op rationalisatie (de huisarts moest sneller en effüciênter kunnen werken) en toepassing van nieuwe vormen van zorgverlening (anticlpatie en survelllance (Van Den Dool), v6rren nazorg (De Melker), electrocardlografie (De Beus, 1969), samenwerking, etc.).

Op deze wijze heeft men zeker met succes de crisis van de huisarts kunnen bestrijden in een gezondheidszorg, waar het particuller inltiatief de boventoon voerde en waar tegenover de overheld een 1 iberale en betrekkelijk passieve houding aannam.

Totdat, en dan zijn we weer op ons beginpunt, diezelfde overheld zich gesteld zag tegenover een steeds duurder wordend stelsel van gezondheldszorg en onder andere daarom de structuurnota (1974) uitbracht. (Minlsterie van Volksgezondheld en Milleuhyglëne, 1974).

Reeds is vermeld, dat de huisarts toch al druk bezet is, hetgeen samenhangt met de relatief grote praktijken en met het verschifnsel dat 1 n de loop der jaren een groter aantal aandoeningen bij de huisarts ter behandeling wordt aangeboden (Hornstra, 1950; Van Deen, 1952; Hogerze11, 1954; Ruhe, 1957; Dopheide, 1982; Van Vliet en Van de Ven, 1982). Het voornemen de eerste lijnsgezondheidszorg te versterken, deed daarom in kringen van KNMG, LHV en NHG al snel de noodzaak gevoelen zich opnleuw op de functie en de taken van de hulsarts te beraden. Er werden studlecommissies ingesteld, die conceptrapporten en nota's over de taken van de hulsarts naar bulten hebben gebracht. (LHV: Conmissie Takenpakket: "Blauwdruk", 1975, KNMG: Commissie Eerste Echelon: "De plaats van de medicus in het eerste echelon", 1976; NHG: Comm1ssie Wetenschappel1jk Onderzoek: "Hoe helpt de dokter?", 1975). Vanult de beroepsopleiding kwam men met een omschrijulng van de taken in de "Kenmerken van de huisarts" (Utrechts Universitair Huisartsen Instituut, 1975). De door het LHV-bestuur aan de leden voorgestelde "Blauwdruk" van de taken van de huisarts omvatte eigenlijk een beleldsvoorstel, dat het hoofd moest bieden aan de te verwachten takkerzwaring vanuit de Structuurnota. Die voornemens behelsden:

- bescherming van de pluriforme beroepsuitoefening; 
- het bevorderen van samenwerking in het eerste echelon; - daling van de rekennormpraktijk met daar aan gekoppeld een maximering van het aantal in te schrijven verzekerden per huisarts.

Dat maximum moest dalen al naar gelang de normpraktijk verder zou dalen. Op grond daarvan zou een vestigingsbeleld worden gevoerd. Om te zorgen, dat de verbreding en de verdieping van het werk van de huisarts metterdaad effect zou krijgen, werd intercolleglale toetsing nodig geacht. Na het verschijnen van de taakomschrijuing in het rapport: "De Taken van de Huisarts" (LHV, 1977) kwam er een "Nieuwe Blauw-

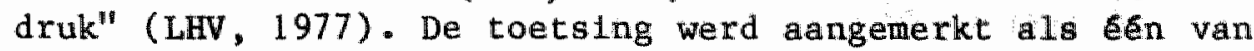
de middelen om de individuele zorg voor de kwalitelt gestalte te geven. Als andere middelen werden beschouwd de opleiding, de nascholing en de samenwerking. Deze mening werd gebaseerd op het feit, dat er nog geen duidelijk en volledig onderzoeksmodel was om de kwalitelt van het werk van de huisarts te toetsen.

Men probeerde de weerstand tegen toetsing weg te nemen door de toetsing te laten plaatsvinden op het onderdeel technisch en organisatorisch functioneren. De toetsing moest bovendien geschieden op vrijwillige basis, bijvoorbeeld in waarneemgroepen. Het vestigingsbeleid werd concreter uitgewerkt. De "Nieuwe Blauwdruk" leek daarmee wat realistischer en meer aangepast aan wat bereikbaar leek. Toch is de door het LHV-bestuur voorgestelde "Blauwdruk" noolt aanvaard, omdat er geen overeenstemming over te verkrijgen was met de achterban.

In de taakrapporten werd op de (brede) taaksteliting van de Woudschoten-conferentie niet afgedongen. Alleen de KNMGcommissie "Eerste Echelon" vond dat de hulsarts bepaalde activiteiten, bestempeld als oneigenlijke taken, zou moeten afstoten in geval er andere werkers of instellingen in de eerste 1 ijn aanwezig zijn, die die taken beter dan de (huis)arts kunnen verrichten. Tot die taken behoren onder andere het verrichten van keuringen en controles en de groepspreventie, zoals het lelden van consultatiebureaus voor zulgelingen en kleuters. Tegen de term onelgenlifke taken werden vele protesten geult, nlet in de latste plaats, omdat sommige huisartsen vreesden, dat met name het afstoten van een keurings- en contrôlepraktijk voor hun een gevoelige daling van inkomsten zou gaan betekenen. De taakstellingen uit het KNMG- (1976) en het LHV-rapport 
(1977) zijn de grondslag geweest voor de operationalisering yan het in dit onderzoek gebrulkte en nog nader te beschrljven systeen van observatie categorieën als meetinstrument voor de takuitoefening. De KNMG-commissie kwam tot de volgende taakstelling

Hoofd taken:

- diagnostiek

- theraple

- Individuele preventie

- samenwerken met andere disciplines

- medische coördinatie

- advisering bij werkhervatting

- selectle en verwijzing

- signalering

- medisch soclaal functioneren

- praktijkorganisatie en registratie

- nascholing

- intercolleglale toetsing

Facultatleve taken:

- behandeling en begelelding van lichte, chronische psychiatrische patiënten

- groepspreventle

(C.B.'s voor zuigelingen, portioscreening, e.d.)

- opleiding voor aankomende huisartsen

- ultgebrelde diagnostiek (E.C.G.'s, audiometrle, e.d.)

Onelgenlijke taken:

- behandeling van ernstige psychosociale problematiek

- het oplossen van strikt sociale problemen

- het verrichten van partussen in een te gering aantal

- het verlenen van hulp bij straatongevallen

- groepspreventle indien hiervoor andere deskundigen aanwezig $z 1 \mathrm{jn}$

- het verrlchten van keuringen

De LHV-comissle kon zoals gezegd, het standpunt ten aanzlen van de onelgenlijke taken niet delen. In het LHV-rapport "De taken van de hulsarts" (LHV, 1977) wordt daarom zeer gespeciflceerd opgesomd wat de hulsarts in leder geval als hoofdtaken moet verrichten en wat hij zou kunnen doen als de mogelijkheden hem daartoe in staat stellen, daarbij uiting gevend aan de opvatting, dat de huisarts de vrijheid tot pluriforme praktijkuitoefening zou moeten behouden. 
Volgens het LHV-rapport zijn de hoofdtaken:

- diagnostiek

- therapie

- kwaliteitsbewaking

- individuele preventie en anticiperende geneeskunde

- samenwerkend functioneren

- verwijzing, coördinatie en werkadviezen

- organisatie, registratie en signalering

Tot de facultatleve taken behoren:

- de verloskunde

- het meewerken aan de beroepsopleiding tot huisarts

Niet alleen de oneigenlijke taken vormen het verschll tussen de rapporten. Het KNMG-rapport formuleert bovendien de voor die taakuitoefening noodzakelljke structurele verhoudingen tussen het eerste, tweede en derde echelon en levert daarmee een beleidsplan dat gericht is op de versterking van het eerste echelon en de afsteming en integratie van de verschlllende sectoren van de gezondheldszorg.

Ondertussen was in 1978 een theoretische fundering onder de taakstelling tot stand gekomen, welke onder andere door Van Aalderen in zijn oratie was aangegeven (Van Aalderen, 1974) en uitgewerkt is in het NHG-rapport: "Methodisch werken" (NHG, 1978).

Dit rapport was elgenlijk een vervolg op het interimrapport: "Hoe helpt de dokter" (NHG, 1975).

De doelstelling van het methodisch werken is de volgende: Huisarts en Wetenschap, 21, p. 323, 1978.

- openstaan voor alle vragen om hulp. De vragen worden samen met de patiënt verhelderd om te beoordelen welke deskundigheld voor de hulpverlenting geboden is;

- samen met de patiént een keuze maken uit de mogel1jkheden voor hulp en dienovereenkomstig handelen, hetzij zelfstand $1 \mathrm{~g}$ dan wel in samenwerking met anderen.

Mogelijk dat die samenwerking met anderen een verlichting kan geven van het werk van de huisarts.

Een verdere verlichting zou moeten komen van de praktijkverkleining.

Uit het methodisch werken blijkt een democratiseringstendens. De patiënt wordt duidelijk in het hulpverleningsproces betrokken. Deze tendens heeft zich voortgezet in de 
LHV-functieomschrijving, welke in november 1981 door de ledenvergadering is aanvaard. We hebben dus niet meer te doen met een definitie. maar met een formeel geaccepteerde, uitgewerkt omschrijving (LHV, 1981).

De bedoelde tendens kont tot uiting in het volgende citaat uit de functieomschrijving: "De functle van de hulsarts is gericht op het helpen van mensen bij het maken van keuzen en $b i j$ de realisering daarvan - ter bevordering of instandhouding van hun welbevinden en optimaal functioneren, 1ichamelijk, geestelijk en sociaal. Als zodanig draagt de functle bij aan de doelstelling van de gezondheldszorg als gehee1" (LHV, 1981, Medisch Contact, nr. 48, p. 1471, 1981).

U1t deze functieomschrijving volgde een jaar later een nieuw "Basis-takenpakket" (LHV, 1982).

Dit basis-takenpakket heeft een normatief karakter en geeft In meer dan honderd taken aan wat de huisarts behoort te doen, zowel op medisch-technisch terrein (curatief, preventief en begeleldend) als ook op het gebled van samenwerking met andere diselplines, het methodisch werken en het betrekken van de patiënt in het behandelingsproces. Het is een pakket van taken warop "elke in Nederland praktizerende huisarts aanspreekbaar is" (LHV, 1982, Medisch Contact, 37, $\mathrm{nr} .4, \mathrm{p} .1596,1982$ ).

In de basisfunctieomschrijuing en in het basistakenpakket 1 is de in 1959 op de Woudschoten-conferentie naar voren gebrachte visie op de functie en de taken van de huisarts volledig aanwezig, aangevuld met het beginsel van de ge$11 \mathrm{jkwaardigheid}$ en mondigheid van de patiënt.

\section{Samenvattende beschouwing:}

Het voorgaande omvat een globaal overzicht van een periode van ruim dertig jaar huisartsgeneeskunde. In het begin van de vifftiger jaren besefte de huisarts, dat zijn taken langzaam maar zeker werden ultgehold en zag hij zich geplaatst tegenover een probleemaanbod waar hij zich machteloos tegen voelde. Het révell heeft hem uit die concurrentiecrisis geholpen. Dankzij rationalisatie (praktijkvoering, werkorganisatie), scholing in gesprekstechniek (Balintbewegling), ontwikkeling van nascholing, de beroepsoplelding na het basis-arts examen en de oprichting van de Huisartsen Registratle Commissie heeft de huisarts zich ge- 
professionaliseerd.

Dit professionaliseringsproces is een aangelegenheld geweest, die zich toch grotendeels binnen de beroepsgroep heeft afgespeeld. Dit naar binnen gerichte professionaliseringsproces is misschien beter te karakteriseren als een vorm van emancipatie. Het zelfbewustzijn van de huisarts is er zeker mee verhoogd en het gevoel van malaise, defaltisme en agressiviteit verminderde.

Een eigen identiteit heeft de huisarts er naar mijn mening niet mee gekregen. Op individuele ultzonderingen na hebben de huisartsen tot nog toe onvoldoende laten zien tot wat voor specifieke hulpverlening zij in stat zijn. Het feit, dat de taakstelling tot op dit moment nog steeds gebaseerd is op visies en ideële uitgangspunten speelt daar een belangrijke rol bij. Dat gebrek aan identiteit liet zich in de vijftiger en zestiger jaren nog maar weinig voelen. De intramurale zorg bleef relatief en absoluut groelen. Er bleef, in samenhang met de hoogconjuntuur, zuigkracht ultgaan van de op zijn minst in technisch opzicht beter lijkende speclalistische zorg. Men had de handen vol met te bewaken wat voor de huisarts behouden moest bl1jven.

Maar toen men de kosten van de gezondheldszorg te hoog vond worden en in 1974-1975 een periode van laagconjunctuur aanbrak werd de rol van de huisarts belangrijk in het beleld van de overheld. Daarmee kreeg de huisarts vrlj plotseling nieuwe kansen om zijn taakstelling inhoud en richting te geven. Dat is een fundamenteel verschil met de situatie in de vijftiger en zestiger jaren. Doch rationalisatie, nleuwe toepassingen en nleuwe visies zijn mijns inziens ontoereikend om de nu geboden kansen uit te buiten. De hulsarts zou zich daarmee alsmaar nieuwe taken, een steeds groter wordende werklast en nog meer verantwoordelijkheden op de hals halen (Huygen, 1978). De voormalige concurrentlestrijd heeft plaats gemaakt voor de noodzaak aan te tonen, dat men werkelijk de zorg levert, wartoe de huisarts bij ultstek in staat is. Men zal moeten laten zien, dat het methodisch werken het risico van de medicalisering kan doen verminderen of dat waar nodig een goede thulszorg geboden kan worden.

Het gaat er om nu relevante aandachtspunten voor zorg te kiezen en er voor te zorgen dat het functioneren van de huisarts daar mede op wordt afgestemd. Het $11 j k t$ mij dat er in plaats van een alomvattende taakomschrijving meer be- 
hoefte is aan een takenpakket dat zich juist kenmerkt door beperking en explicitering van voor de huisarts functionele aandachtspunten in de hulpverlening.

Buma (1959) heeft gewezen op de noodzaak om door middel van onderzoek tot een meer empirische onderbouwing van de functie en de taken van de huisarts te komen. Ik denk dat deze visie juist is. Daarmee verkrijgt men inzicht in de feitelijke omvang van de taken, de verhouding en de afstemming tussen de taken onderling, de knelpunten in het functioneren en welke factoren met de taakuitoefening samenhangen. Dat bledt mogelijkheden voor een haalbare specificering in het functioneren en houvast in de selectie van wat verder ultgebouwd verdiept of aangevuld zou kunnen worden en waarin men zich zou kunnen beperken om aan nieuwe situaties of behoeften het hoofd te bieden. Tevens krijgt men zicht op mogelijke gedragskenmerken in het functioneren ten aanzien van bepalde taken.

Helaas is aan het verrichten van empirisch taakanalytisch onderzoek nog weinig aandacht besteed (Lamberts, 1982). Er zijn op dit gebled wel degelijk onderzoeken uitgevoerd, met name door Van Deen (1952), Hogerzel1 (1954), Buma (1949, $1952,1959)$, Ruhe (1957), Van der Wielen (1960), Jansen-Enmer (1958), oliemans (1969), Raupp (1971), doch op uitzonderingen na (onder andere Van der Wielen Buma Raupp) werden ze in énmanspraktijken verricht met bovendien uiteenlopende probleemstelingen.

\subsection{Vraagste11ing van het onderzoek.}

In de voorgaande beschouwing 1 s de behoefte aan empirische gegevens ten aanzien van de taakuitoefening van hulsartsen aangegeven. Hteruit is de volgende vraagstelling voor dit onderzoek ontstiáan:

1. Welke taakdimensies zljn ex af te leiden uit de activitelten, de huisartsen dagelifks verrichten, met andere woorden: op welke taken is het werk van de hulsarts feltelljk gerlcht?

2. In hoeverre hangen verschilien in taakultoefen1ng samen met kenmerken van de werksituatie, de werkwijze en de persoon van de hulsarts?

Vanult deze vraagstellingen willen wij met het onderhavige observatie-onderzoek een empirische exploratie verrichten 
naar de doelen, die de huisarts met zijn handelen tracht te bereiken of, met andere woorden, naar de feitelijke taakstructuur, die achter het handelen van de huisarts schullgaat. Daarmee onderscheldt dit onderzoek zich van de in Nederland reeds ondernomen praktijkanalytische onderzoeken. De andere onderzoeken 0.a. Buma (1959), Van der Wiellen (1960), Jansen-Emmer (1958), Raupp (1971), Boots (1983), waren meer gericht op de betekenis van de hulsarts voor de gezondheidszorg of op de doeltreffendheld van die zorg. Het onderzoek van Boots (1983) en het onderhavige hebben een gemeenschappelijke oorsprong. In nauwe samenwerking hebben Boots en ik een observatie-onderzoek in 93 hulsartspraktijken en een taakperceptlemeting opgezet en uitgevoerd. Het daarult voortgekomen gegevensbestand is vervolgens door leder van ons met verschillende probleemstelling geanalyseerd. Op deze wijze zijn door beide onderzoekers verschillende facetten van én gezamenlijk verricht onderzoek be1icht. Het onderzoek van Boots (1983) betreft een functieanalyse met het doel, de plaats, die de huisarts in de Nederlandse gezondheidszorg inneemt empirisch te beschrijven. De werkzaamheden van de huisarts werden daartoe schematisch ingedeeld in zes functies en geoperationaliseerd in direct waarneembare activiteiten. De indeling vond plaats aan de hand van het normatieve taken-pakket van de huisarts, beschreven door commissies van (huis-) artsen op verschillende momenten in de ontwikkeling van het huisartsenberoep en met verschillende doeleinden. Boots heeft een kwantitatieve bepaling van de rol van de huisarts in de gezondheidszorg bereikt door langs empirische weg te meten hoe qua tijdsbesteding de zes onderschelden functies zich ten opzlchte van elkaar verhouden. Mijn onderzoek is gericht op een exploram tile van de taakdimensles in het werk van de hulsarts en het verklaren van verschillen in taakuitoefening met als doel een bijdrage te leveren aan het vergroten van het inzicht in de structuur en het functioneren van wat ondanks alles nog steeds als een centraal deel van onze gezondheldszorg wordt gezien, namelijk de huisartsgeneeskunde.

\subsection{De indeling van de rapportage.}

Na deze inleiding en de beschrijving van de vraagstelling volgt in het hiernakomende hoofdstuk een rapportage van de literatuurverkenning, die in relatie tot de vraagstellingen 
is verricht. In hoofdstuk 3 wordt de observatiemethode in het onderzoek uiteengezet. In het bijzonder wordt daarbij aandacht besteed aan het systeem van observatiecategorieën. In hoofdstuk 4 worden de opzet en de uitvoering van het onderzoek beschreven. Daarna volgt in hoofdstuk 5 de beschrijving van de gemeten variabelen: In hoofdstuk 6 staan de resultaten van de eerste vraagstellingen vermeld. In hoofdstuk 7 wordt het onderzoek naar de verschillen in taakuitoefening beschreven. In hoofdstuk 8 volgt tenslotte een samenvatting van de belangrijkste bevindingen en een bespreking van de betekenis, die aan de resultaten kan worden toegekend.

Uit oogpunt van volledigheld van opbouw van deze rapportage en om het de lezer gemakkelljker te maken, heb $1 k$ gemeend, ook al omdat het een resultaat van gezamelijk werk betreft, on in hoofdstuk 4 en 5 de beschrijuing van de opzet en de uttwoering van het onderzoek èn van de variabelen en de meetresultaten te moeten herhalen in plaats van simpelweg te verwijzen naar het proefschrift van Boots. Voor de beschrijuing van de gegevensverzameling (4.4) heb lk daarom vrijwe 1 letterlijk de paragrafen 3.2 . en 3.4 . (pp. 42, 43, 46) van Boots overgenomen.

In 4.5. wordt de keuze van de methode van observatie besproken (PP. 48-50 van Boots). In de paragrafen 4.6 . en 4.7. geef ik een beschrijving van de ultwoering van de observaties, de taakperceptiemeting en het samenstellen en controleren van de steekproeven. Deze beschrijving is ontleend aan de paragrafen 4.4 en 4.5. van Boots (pp. 53-63). In hoofdstuk 5 komen de opzet van de taakperceptiemeting, de meetresultaten ervan en de constructie van de variabelen: taakbreedte diagnostisch en therapeutisch niveau, bereldheld tot samenwerken en tifd/voorzieningen aan de orde. De beschrijuing hiervan komt overeen met de tekst van paragraaf 5.3. van Boots (pp. 70-74). 
Hoofdstuk 2. De 11teratuurverkenning met betrekking tot de probleemstelling.

2.1. Inleiding.

In dit hoofdstuk wordt verslag gedaan van de literatuurverkenning in relatie tot de vraagstellingen.

De daarvoor relevante literatuur is schematisch als volgt in te delen:

1. Praktijkonderzoeken naar de taakuitoefening van de huisarts.

2. De omschrijving van de taken van de huisarts vanuit en door de beroepsgroep van huisartsen.

3. Onderzoeken, gericht op factoren, die met de taakultoefening van de huisarts samenhangen.

De hierboven vermelde rubrleken 1 en 2 zijn van belang voor de eerste vraagstelling en worden behandeld in paragraaf 2.2. en 2.3. De derde rubrlek heeft betrekking op de tweede vraagstelling en komt aan de orde in paragraaf 2.4 .

\subsection{De taken van de huisarts.}

Voor het literatuuroverzicht met betrekking tot de eerste vraagstelling is gebruik gemaakt van de volgende studies: Van Deen (1952); Hogerze1l (1954); Ruhe (1957); Jansen-Emmer (1958); Buma (1959); Van der Wielen (1960); Bremer en Van Westreenen (1964); Oosterhuis (1972); Raupp (1971); Bremer (1978); Boots (1983).

Ten aanzien van de Nederlandse sltuatie zijn deze onderzoeken als de belangrijkste informatiebronnen te beschouwen.

Het werk van Van Deen (1952) betreft een arbeldsanalyse in zijn plattelandspraktijk over een periode van drie maanden. Het doel was de hoeveelheid en de soort arbeld die aan de verschillende patientengroepen werd verleend, te bepalen. Daarvoor was het nodig alle werkzaamheden, die in de praktijk voorkomen te inventariseren. De auteur heeft daarbij gebruik gemaakt van de methode van de tijd- en bewegingsstudie, zoals die in het bedrijfsleven door arbeidsanalisten wordt gebruikt. Behalve zijn werkzaamheden heeft hij ook de gedlagnostiseerde aandoeningen geregistreerd, alsmede een aantal gegevens en kenmerken van de behandelde patiènten. 
Belangr1jk voor ons is dat de werkzaamheden c.q. verrichtingen in 63 categorleën zifn 1ngedeeld; 32 daarvan kwamen vaak of zeer geregeld voor. Deze categorieên verwijzen naar de volgende taken:
- diagnostiek
anamese, 1ichamelijk onder- zoek, eigen laboratoriumon- derzoek
- behandeling
medicatie (via elgen apo- theek), therapeutische ingre- pen en handellingen, psycho- therapeutisch gesprek
- verwijzen naar brieven schrijven aan speci- specialisten
- verloskund 1 ge hulp en preventie alist, consultatie, e.d. zwangerschapscontrole, hulp bij partus, controle van het kraambed, vaccinaties
- eerste hulp wond behandeling

Daarnaast zijn werkzaamheden onderscheiden en geregistreerd, die betrekking hebben op de praktijkvoering, zoals:

- apotheekwerkzaamheden

- opruimen van de spreekkamer

- het rijden van visites en houden van spreekuur

- administratie

Aanvankelijk lag het in de bedoeling om ook in andere praktijken gegevens te verzamelen ter vergelijking en aanvul1ing. Het ultwerken van de eigen gegevens bleek echter zo t1jdrovend, dat daarvan moest worden afgezien. De resultaten hebben betrekkıng op én praktijk en zijn dus niet algemeen geldend.

Toch geven deze resultaten een indicatle van de taken van de hulsarts, zonder dat in de bespreking van de resultaten aan een expllclete takindeling gerefereerd wordt. De resultaten zijn meer gespecificeerd in:

- omvang van verrichtingen naar categorie van patiënten: ziekenfondsverzekerden en particuliere patlënten;

- noodzakelifkheld van de verrichting;

- wat door hulpkrachten gedaan had kunnen worden;

- morbiditeit;

- factoren, die een goede verzorging van de patiënt bevorderen of belemmeren.

Verder is interessant. dat voor het vastleggen van de ver- 
richtingen van de arts gebrulk is gemaakt van een tijdstudlemethode. De tijden zijn opgenomen met een horloge of een chronometer. Alles werd genoteerd, zoals het in werkelijkheid is gebeurd en door de onderzoeker zelf. Voor Van Deen zag een gemiddelde werkdag er als volgt ult:

Totaal aantal werkuren 11.5 , die als volgt konden worden onderverdeeld:

- voor het verzorgen van 2080

patiënten

9.4 uur

- op peil houden van vakkennis,

medische vergaderingen, etc.

1.4 uur

- preventlef werk

0.3 uur

- keuringen en contrôles

0.4 uur

11.5 uur

In de 9.4 uur patiëntenzorg zat een vaste post van 3.2 uur voor administratle, oprulmen van de spreekkamer, etc. (Van Deen werkte zonder assistente), zodat er elgenlijk 6.2 uur besteed werd aan directe patiëntenzorg. Van Deen schatte, dat een praktijkassistente een gedeelte van het werk zou kunnen overnemen, overeenkomend met 2.3 uur per dag.

Het aantal verrichtingen per werkdag bedroeg gemiddeld voor 2080 patiënten:

- $\quad 18.9$ consulten

- $\quad 20.3$ visites

- $\quad 8.5$ verrichtingen buiten aanwezigheid

van de patiënt (laboratorium, apotheek, etc.)

$16.2 \%$ van de tijd voor alle verrichtingen werd besteed aan zogenaamde buitentijdse verrichtingen (navisites, e.d.).

Hogerze11 (1954) deed ook een studie in de elgen praktijk. Het doel was hier inzicht te verschaffen in de resultaten, die de hulsarts in zijn praktijk bereikt naar aanleiding van de klacht van de patiënt, de diagnose van de arts en de therapie van hen beiden.

Van de patiènten werden een aantal sociologische kenmerken, zoals beroep of beroep van het gezinshoofd, godsdienst, stabllitelt etc. verzameld, maar in de beschrijuing van de resultaten wordt hier niet meer op teruggekomen en komt alleen de man-vrouw verhouding en het onderscheld tussen fonds en nlet-fonds ter sprake. De resultaten hebben betrekking op een onderzoeksduur van drie maanden. Uit die perlode wordt het aantal verrichtingen vermeld evenals het 
aantal ziektegevallen, ingedeeld volgens een eigen symptoom-dlagnose stelsel. Evenals bij Van Deen treffen we daarnaast een diagnostisch overzicht aan volgens de 17 hoofdgroepen ult de $\mathrm{z} \cdot \mathrm{g}$. Internationale Lljst. Voorts worden de resultaten van de therapie en de soort en het aantal verrichtingen beschreven in relatie tot het ontwikkelde stelsel van symptoomdlagnosen.

Hogerzlel heeft getracht een werkmethode te ontwikkelen ter verwerking van het klachtenaanbod en de hulpverlening. Uit de verrichtingen zijn geen aanwijzingen af te leiden voor een takindeling van de huisarts.

Ruhe (1957) deed een onderzoek in de elgen prakt1jk. Het leek hem de moeite ward, na een ongeveer twintigjarige werkzaamheld als hulsarts in steeds dezelfde praktijk, aan de hand van de gegevens uit die praktijk na te gaan, wat er in die periode zoal veranderd was. Hij maakte een vergelijking tussen de jaren 1938 en 1954 . De patiënten werden ingedeeld naar godsdienst, beroep, financlële relatie tot de hulsarts en milieu warin ze leefden, hetgeen mogelijk was omdat de schrijver vanaf zijn eerste dag van vestiging dagelijks in een journaal nauwkeurig aantekenlng placht te houden van alle verrichte medische arbeld. Van elke patiexnt die hij zag, hetzij thuis, hetzij op het spreekuur werden de naam en verdere antecedenten genoteerd, alsmede de klachten, de gevonden afwijkingen met vermelding van diagnose, theraple en resultaat van de behandeling. Van elke bevalling werd een kort verslag gemakt. Er was een afzonderlijke lijst voor geboortes en sterfgevallen.

Utt het patientenbestand werd een selectie gemakt op grond van de woonplaats, omdat voor de oorlog gepraktiseerd werd in viff gemeenten en na de oorlog in twee. Vervolgens werden dle patiénten Ingedeeld naar godsdlenst en beroep. Zo kwam ten aanzlen van de "curatleve geneeskunst" een verge$11 \mathrm{jking}$ tot stand van de medische verrichtingen v $6 \sigma \mathrm{r}$ en na de oorlog. Daarult kwam naar voren, dat het aantal mensen, dat de huisarts in een jaar tijd niet raadpleegde na de oorlog bijna gehalveerd was en het aantal ter behandeling gekomen aandoening zich verdubbeld had. Vooral de "lichte" aandoenlngen waren toegenomen. Het aantal verwijzingen naar de speclalist was verviervoudigd. Onder invloed van de matschappelljke veranderingen bleek de behoefte aan geneeskundige verzorging sterk toegenomen. In samenhang hier- 
mee noemt de auteur onder andere het feit, dat voor de oor$10 \mathrm{~g}$ mlnder dan $20 \%$ van de patiënten uit deze praktijk 11d waren van het ziekenfonds en na de oor $\log 72 \%$, hetgeen overeenkwam met het landelljk gemiddelde. Ten aanzien van de verloskundige zorg was de grootste verandering te constateren. Voor de oorlog was de taak van de huisarts vooral geconcentreerd op curatieve hulp bij de partus en het ultvoeren van kunstingrepen, zoals versie en extractie, forceps e.d., na de oorlog was het accent komen te liggen op de vo6rzorg, de begelelding van de zwangerschap en werd hoogstens nog een uitgangstang toegepast. Ook deze verschuiving is door medisch-maatschappelijke veranderingen tot stand gebracht. De ontploollng van de kruisverenigingen heeft hieraan zeker bijgedragen.

Hoewel dit onderzoek betrekking heeft op de curatieve zorg van de huisarts in eén enkele praktijk, komen toch aanwijzingen naar voren wat betreft de verschuivingen in de taak van de huisarts. De hulsarts kreeg een groter aanbod van aandoeningen en vooral een andersoortige pathologie ter behandeling. Hij is patiënten vaker naar specialisten gaan verwijzen en zijn aandeel in de verloskundige zorg heeft een duidelijke preventieve dimensie er bij gekregen.

Jansen-Emmer (1958) deed een observatie-onderzoek in vier huisartspraktijken in Amsterdam. De vier huisartsen werden tijdens het spreekuur geobserveerd. In tegenstelling tot het onderzoek van Van Deen (1952), die zich zelf observeerde, is het onderzoek van mevrouw Jansen een voorbeeld van een niet-particlperende observatie. Op de verschillende vormen van observatie-onderzoek zal nog worden teruggekomen in hoofdstuk 3. Het onderzoek is echter geen tijdstudie. Van elk arts-patient contact op het spreekuur werd op een speciaal daarvoor ontworpen kaart genoteerd: de datum, de duur, de ernst, het aspect van de klacht of de andoening, de diagnose en de theraple, alsmede de verwijzingen en de opnemingen in het ziekenhuis. Verder konden bif elk van de huisartsen de kaartsystemen worden ingezien. Het doel van het onderzoek was on:

- van een zeker patiëntenmateriaal (ult verschillende Amsterdamse wijken) een indruk te krijgen omtrent het geestelijk, 1ichame1ijk en matschappelljk welbevinden. 
- een 1 indruk te krijgen van de omvang en de aard van de arbeld van de hulsarts in die situaties, met andere woorden een inzlcht te verkrijgen in de wijze waarop enkele hulsartsen zich van deze taak kweten.

De eerste praktifk is precles een jaar lang geobserveerd, de tweede en derde drie maanden en de vierde een half jaar. Wat de gegevengverzameling betreft komt het onderzoek overeen met dat van Buma (1962), die een inventarisatie maakte van $\mathbf{2} 1$ jn huisartspraktijk in Ridderkerk in de jaren 1947 en 1950, en ook met dat van Van Deen (1952) en Ruhe (1957). In de resultaten gaat het vooral on antallen verrichtingen (consulten, visites) per dag en verder het gemiddeld aantal ultgeschreven recepten, het gemiddeld aantal aandoeningen en verrichtingen in relatie tot enkele matschappelijke factoren (woonsituatie, e.a.) de sexe, de leeftijdopbouw, het beroep en de gezinsgrootte. Zij vond, dat de helft van de "normale" gezinnen kampte met problemen van psychische en/of sociale aard. De huisarts heeft dan ook in de helft van de gevallen te maken met psychosociale problematiek. Interessant is haar opvatting over de taak van de huisarts terzake. De huisarts zal die psychosociale achtergrond moeten herkennen. Hij zal daar inzicht in moeten krljgen, ondanks het feit dat er voor psychosociale moellijkheden veelal geen afdoende therapie geboden kan worden. Dat is niet zo erg, vindt zij, omdat de meeste mensen in die omstandlgheden tot een modus vlvendi komen. Ze erkent, dat bifvoorbeeld marginalen marginaal blijven. ook al zou de sltuatle veranderd worden, dan komt er toch weer wat anders voor in de plaats. Naar haar mening behoeft op dit gebled de werkzaamheld van de hulsarts niet verder te gaan dan een goede kennis van de mogelijkheden voor hulp, die er buiten de medische feer bestaan. Het verkrijgen van dle goede kennis is een kwestle van opleiding, waraan het echter haars Inziens ontbreekt. Daar komt nog bif dat door het grote, gemiddelde antal verrichtingen per dag (50 à 60 per dag bif een gemlddelde praktijkgrootte van rond de $3500-$ 4000 zlelen) de hulsarts onvoldoende in de pschosociale problemen van zijn patiënten kan doordringen en hij niet toekomt aan een behoorlijke samenwerking met andere disclplines. Hij heeft er de tijd niet voor!

Deze studie werpt dus een licht op de sterk toegenomen psychosociale problematiek bij de huisarts en houdt een voorstel in tot taakdeling: de herkenning van deze problematiek 
is een taak van de huisarts, voor eventuele behandeling en begelelding moet verwezen worden nar en samengewerkt worden met andere disciplines.

Een ander belangrijk observatle-onderzoek is ondernomen door Buma (1959). Hij observeerde in de tweede helft van 1958, telkens gedurende één etmaal en zoveel mogelijk tijdens "normale" werkdagen, alle verrichtingen van een tiental hulsartsen met behulp van een daartoe bestemd formulier. Het doel was drieërlei:

- "het verkrijgen van een globaal inzicht in de aard en de omvang der vraagstellingen, zoals deze zich aan de huisarts presenteren (morbiditeitsonderzoek);

- het verkrijgen van een indruk over het totaal van taken van allen die met de behandelde ziektegevallen te maken hebben, door middel van een systematisch gesprek met de betrokken huisarts over elk zich presenterend ziektegeval (taakanalyse);

- het vastleggen van het aandeel in dit totale taakgebiled; dat voor rekening van de huisarts komt". (...)

Uit het aantal en de aard van de patiëntencontacten komt de schrijver tot een beschouwing van en een brede visie op de mogelijkheden voor zorgverlening, welke de hulsarts, maar voora1 de hulsartsen als groep, als collectlef te midden van de werkers in de gezondheidszorg, geboden worden. Aan de hand van de uitkomsten van dit onderzoek zijn de functie- en de taakomschrijuing van de Woudschoten-conferentie in 1959 geformuleerd. De functie-omschrijving en de strikt medische taken van de hulsarts (twalf in getal) $z 1 j n$ reeds besproken in hoofdstuk 1 .

De studie van Van der Wielen (1960) is een groots opgezet observatie-onderzoek in een aselecte steekproef van 268 huisartsen, gecombineerd met een enquete naar de werkomstandigheden van die huisartsen. Alle 268 hulsartsen zijn leder door én van de vier geinstructeerde arts-enquêteurs gedurende twee dagen geobserveerd. Er werden daarb1j in totaal 19815 arts-patiềnt contacten geregistreerd. Het doel was het bepalen van de doeltreffendheid van de door de huisarts geleverde gezondheldszorg. Het accent 1 ag dus op een meting van de $k$ waliteit. Het hulsartsenwerk werd onderschelden in: 
- curatieve zorg, en

- voorzorg (preventie).

De curatieve zorg werd onderverdeeld in anamese (onderzoek), therapie en verwljzing, waarbij elk van deze categorleèn weer een grove onderverdeling kreeg. De preventle werd voornamelijk onderschelden naar prenatale zorg, de zorg voor zulgellngen en de vaccinaties.

Een emplrische beschrijving van de taken van de hulsarts leverde het onderzoek niet op. Bij de bestudering van de gevonden motteven voor het arts-patiënt contact, zowel die van de patiënt als die van de hulsarts, viel het in dit onderzoek op, dat "in verhouding tot het curatieve werk de preventieve verrichtingen geen belangrijke plaats innamen". Z1j werden in aantal voorbijgestreefd door de verwijzingen naar de spectalist of door de herhalingsrecepten" (op. cit. p. 101). Ook hier dus een aanwijzing dat de huisarts zich voornamelijk bezlg houdt met curatieve zorg.

Tijdgebrek is het belangrijkste knelpunt voor de kwaliteit, in casu de doeltreffendheid van de zorg. Er is te weinig tijd voor het arts-patiënt contact. Dit zou verbeterd kunnen worden door een effictëntere praktijkorganisatie (afspraakspreekuren o.a.) en kleinere praktijken van 2000 zielen.

Bremer en Van Westreenen (1964) deden een onderzoek in hun eigen praktijken; een plattelands- en een stadspraktijk. $\mathrm{Zij}$ analyseerden 2630 arts-patiënt contacten. De werkzaamheden werden naar frequentle van voorkomen in een tevoren bepaalde periode geregistreerd. Het was niet goed mogelijk In het kader van dit onderzoek de factor tijd in te voeren. Meer dan $80 \%$ van de contacten vond plaats om curatieve redenen. Het aantal curatleve contacten was bijna vijfmaal zo groot als het aantal preventieve. De preventleve contacten vonden vooral plaats met kinderen tot ongeveer zes jaar. Naarmate de leeftIjd van de patiénten toenam, nam het aantal preventieve contacten af: kinderen $43,8 \%$, volwassenen $10,3 \%$, bejaarden $1,1 \%$. Door de te verwachten toeneming van de urbanisatie en de trend, dat de zulgelingen- en kleutercontrole meer in de ambtelijke sfeer zullen komen te $1 \mathrm{ig}$ gen, verwachten de schrljvers dat die preventietaak in de toekomst voor de hulsarts nog kleiner zal worden.

Wat de behandelling betreft werd in $40 \%$ van de contacten een geneesmiddel voorgeschreven. Bejaarden kregen in meer dan 
de helft van de gevallen een medicament. Deskundige medisch-farmaceutische voorlichting aan de hulsarts is daarom noodzakelijk. Betrekkelijk vaak blijkt de huisarts aan zijn patiênten adviezen te verstrekken. Het vraagstuk van de geboorteregeling is daarbij zeer belangrijk. De huisarts moet in staat zijn alle nodige adviezen op het gebled van de geboorteregeling te kunnen geven. De onderzoekers verwachten dat deze taak in de toekomst aan belang zal winnen.

Een zeer belangrijke taak van de huisarts is het verwijzen. In dit onderzoek kwam verwijzen in $7,5 \%$ van de contacten voor. Blj dat verwijzen moet de huisarts een goede selectle maken en hij moet het besluit goed motiveren.

Verder viel op dat bij tal van werkzaamheden het "spreken", de gespreksvoering een grote plaats inneemt. Met die werkzaamheden tracht de hulsarts uiteindelijk de volgende doelen te bereiken: diagnosestelling, behandeling, verwijzen, begeleiding en preventie.

Oosterhuls (1972) beschrijft een willekeurige dag uit $z i j n$ huisartspraktijk en geeft daarbij aan welke rollen hij voor zijn patiënten vervulde. Hij komt tot acht rollen: genees-, heel- en verloskundige, medisch psycholoog, maatschappelijk werker, surveillant van risicodragenden, administrateur en archivaris, coördinator van medische bemoelenissen, gezinstherapeut en pastor.

Uiteraard weerspiegelt dit beeld sterk de persoonlijke instelling van deze huisarts, maar desondanks kunnen we ook uit dit beeld taakdimensies afleiden. Uit de rol van genees-, hee1-, en verloskundige is zonder meer diagnostiek, behandeling, verwijzen en uiteraard de prenatale en verloskundige zorg af te leiden. Uit de beschreven casulstiek is daar aan toe te voegen: gezinsplanning c.q. geboorteregeling en kleutercontrole. Voorts: survelllance, secundaire en tertiaire preventie van rlsicopatiènten en chronisch zleken.

Ook hier is gespreksvoering met als oogmerk informatie verstrekking en theraple zeer duidelijk als doel herkenbaar. Uit het coördinatorschap voor medische bemoeienissen blifkt een functioneren en een takkvervulling zoals De Melker (1973, 1975) beschrijft van de huisarts ten aanzien van zijn in het ziekenhuls opgenomen patiënten. 0osterhuls geeft echter zelf al aan dat ziekenhulsbezoek er bij inschlet als hij meer dan 10 visites per dag heeft en dat 
kwam nogal eeng voor. Tegelljk geeft hij aan dat de bijscholing in de zlekenhulzen ook op drukke dagen toch bezocht wordt. Daarmee en met het ontvangen van artsenbezoekers en door kennis te nemen van farmaceutlsche reclames geeft Dosterhuls er expliciet blijk van, dat nascholing een doelstelling is in $\mathrm{z} I \mathrm{Jn}$ (de) werkzaamheden als huisarts.

Bremer (1978) beschrijft in navolging van oosterhuis ook een wllekeurlge dag in $z 1 j n$ praktijk, maar volgt een ander stramfen. BH hem staat de vraag centraal: Welke factoren en overwegingen zijn van belang bij de ontmoeting met de tnd1viduele patient? Daarom is het moeilijk om uit deze beschrljuing expliclete taken af te leiden.

Het komt er op neer dat het nog on dezelfde taken gaat als in 1964 (Bremer en Van Westreenen, 1964). Toch krijgen bepaalde zaken een accent. Zo constateert hij dat voor de huisarts "oude gegevens" betreffende de patient van veel belang zijn voor het beleid. Dit wijst er op dat het opstellen van een probleemlijst en het nauwgezet vastleggen van gegevens van patienten een belangrifke taak van de hulsarts $1 \mathrm{~s}$.

Wat hem verder frappeerde was dat medisch-maatschappelijke ontwikkelingen veel meer invloed op het werk van de hulsarts hebben dan zuiver medisch-technische. Zo zijn ongeveer $20 \%$ van $z 1 j n$ arts-patiënt contacten bedoeld voor geboorteregeling en gezinsplanning, (volgens het onderzoek van Ollemans en De Waard, I.M.0. 1969, zou in $19698,3 \%$ van a1le verrichtingen in deze categorle vallen), maar door de daling van het antal geboortes en doordat meer vrouwen klintsch wilen bevallen is de omvang van de verloskundige taak afgenomen. Daarentegen $z i j n$ door ultbrelding van de laboratorlummogelijkheden de diagnostische mogelijkheden vergroot. Door allerlel, vaak onduldelijke oorzaken is het aantal hulsbezoeken sterk gedaald.

Het geven van onderwljs, in dit geval aan een staglaire van een opleiding tot doktersassistente, wordt in deze praktijk als taak genoemd.

Het onderzoek van Raupp (1971) had vooral ten doel verschillen 1n werkwijzen of 1 in werkpatronen, die er bestaan tussen hulsartsen, te beschrijven met behulp van factoren, die rechtstreeks betrekking hebben op de hulsarts en op zijn praktijk. Het onderzoek is uitgevoerd onder 200 in 
Zuid-Limburg bif het ziekenfonds Zuld-Limburg ( $Z Z L$ ) aangesloten huisartsen. Naast een aantal persoonskenmerken van de hulsartsen werden gegevens gelnventarlseerd met betrekklng tot de wijze waarop de patiëntencontacten geregeld waren, de wijze waarop een aantal gezondheldszorgtaken inhoudelijk en naar frequentile van voorkomen werden uitgevoerd (pilcontrôles, pre- en perinataal onderzoek, enz.), de frequentie en de tijdsbesteding van verrichtingen, die nodig waren voor de praktijkvoering (laboratorlumwerk, administratie, overleg met specialisten, e.d.). Ook werden de instelling en de tevredenheld van de huisarts ten aanzlen van zijn werk gemeten.

Uit de resultaten komen een achttal werkwijzen naar voren. Het onderzoek levert voor ons geen aanwijzingen op omtrent het feitelijke takenpakket van de hulsarts. Van belang is wel, en dat vooral voor onze tweede vraagstelling, dat de variantie in de werkwijze voor $50 \%$ bleek samen te hangen met de volgende variabelen:

- de praktijkgrootte

- de afstand tot het ziekenhuis

- de nascholing van de huisarts

- de beroepsbeleving van de huisarts (factor II)

- de leeftijd van de huisarts

Het onderzoek van Boots (1983) heeft dezelfde oorsprong als het onderhavige. De gezamenl1jke basis wat betreft opzet en uitvoering, komt nog uitvoerig aan de orde in het volgende hoofdstuk. Het doel was hier een beschrijving te geven van de functies, die de huisarts in de Nederlandse gezondheldszorg vervult en na te gaan in hoeverre verschillen in functie-uitoefening te verklaren zijn vanult de taakopvatting van de hulsarts, de persoonskenmerken van de huisarts en de structuur van de gezondheldszorg. Gekozen werd voor een schematische aandulding van de functies. Als observatiecategorieën voor deze functies werden 43 activitelten gespeciflceerd. Met behulp van dit systeem van observatiecategorieën is in een gestratiftceerde steekproef van 93 hulsartsprakt $1 j k e n$ een tijdstudie ultgevoerd gedurende 4 a 5 halve dagen in een week per praktijk. Met deze schematische functie-indeling werd een beeld verkregen van de verdeling van de tIjdsbesteding naar de verschillende functles. Bljna $40 \%$ van de tijd werd besteed aan curatieve zorg en ruim $11 \%$ van de tijd namen de functies "begelelding" en "preventie" 
In beslag. Het gemiddeld aantal verwijzingen per 100 consulten bedroeg 9,9 .

De verschillen in tijdsbesteding aan "diagnostiek" "therapie" en "kondlties" konden voor ruim $30 \%$ verklaard worden, waarbif vooral de factor: het gemiddeld patièntenaanbod van betekenis bleek. Een groter gemiddeld patiëntenaanbod hing samen met een kleiner aantal verwijzingen. Naarmate de prakt1jkonvang toenam, werd een groter aantal patiënten per uur aangetroffen.

Meer praktijkervaring van de huisarts ging samen met meer "begelelding" en minder verwijzingen.

Werd een hoger diagnostisch en therapeutisch niveau van werken nagestreefd dan steeg de aandacht voor preventie en daelde het aantal verwijzingen.

Hulsartsen, die vinden, dat ze veel gebruik maken van de aanwezige voorzleningen in de gezondheidszorg, bleken veel tiJd aan diagnostiek te besteden.

De opvatting over de taakbreedte speelde slechts een interveniërende rol. Hulsartsen met een relatief brede taakopvatting waren minder afhankelijk van de omstandigheden waronder zlj hun werk moesten ultoefenen, ze streefden een lager niveau van somatische diagnostiek en theraple na, waardoor ze relatief meer tijd beschikbaar kregen voor "begeleiding".

\section{Samenvatting.}

Het onderzoek van Van Deen (1952) en van Boots (1983) z1jn echte tijdstudies, gericht op het werk van de huisarts. Verdere grote observatie-onderzoeken zijn die van JansenEmmer (1958), Buma (1959), Van der Wielen (1960). Deze hebben plaatsgevonden in meerdere praktijken. Het onderzoek van mevrouw Jansen betrof vooral verrichtingen, dat van Buma had betrekking op de blj de hulsarts aangeboden morbiditeit, van waarult de mogelijkheden en de betekenis van de zorgverlening door de huisarts nader werden bezlen. Het onderzoek van Van der Wielen betrof voornamelijk de kwaliteit van de hulpverlenting van de huisarts in termen van doeltreffendheld.

De onderzoeken van Ruhe (1957), Bremer en Van Westreenen (1964), 0osterhuls $(1972)$, Bremer (1978) vonden plaats in de elgen praktijken en waren gericht op verrichtingen. Bremer en Van Westreenen koppelden daaraan een beschouwing 
over de mogelijke ontwikkelingen in de toekomst.

Raupp (1971) deed een enquete- onderzoek naar de werkwijze van huisartsen. Boots (1983) gaf een beeld van de relatileve tijdsbesteding van de functies van de huisarts aan de hand van een schematische functle-indeling.

Uit al deze empirische beschrifvingen komt de volgende structuur in het werk van de huisarts naar voren:

- diagnostiek, therapie, verwijzen naar specialisten, kortweg de intercurrent-curatieve zorg;

de preventie, als primalre vorm ten anzien van geboorteregeling, gezinsplanning, zuigelingen- en kleuterzorg, verloskundige zorg;

preventie, als secundaire $c . q$. tertiaire vorm als nazorg en follow-up, als survelllance en begeleiding voor risicodragenden en chronisch zlleken;

- praktijkmanagement, registratie, archivering;

- informatieverstrekking aan de patiënt zelf of aan familieleden, c.q. gespreksvoering;

coördinatie van zorg, samenwerking in overleg met andere hulpverleners;

nascholing;

het geven van onderwijs;

contrôles en keuringen.

2.3. De omschrijving van de taken van de hulsarts.

In hoofdstuk 1 is reeds gememoreerd, dat een basisfunctieomschrijuing in november 1981 door de LHV-ledenvergadering werd aanvaard. Uit deze basisfunctie-omschrijving volgde een jaar later een nleuw "Basls Takenpakket" (LHV, 1982). Dit Basis Taken Pakket dient voor de volgende doeleinden:

- Een visie op huisartsgeneeskunde en het zichtbaar maken van de bijdrage van de hulsarts aan de gezondheldszorg.

Een formulering van de taken, warop de Nederlandse huisarts ten minste aanspreekbaar is.

De opleiding, de nascholing, de toetsing en het wetenschappe11jk onderzoek.

- Een voorwaardenscheppend beleid ten behoeve van ondermeer taakafbakening, honorerıng en normering van de praktijkgrootte.

Het ultwerken van deze doeleinden naar taken werd door de 
Comissie Takenpakket niet rechtstreeks mogelijk geacht. Op basls van het "Methodisch Werken" werden daaram de verschlllende stappen ult het hulpverlenlngsproces van de hulsarts geplaatst in een model. Om alle facetten van het werk van de hulsarts aan de orde te laten komen werd daarnaast voor andere 1 ingangen gekozen, namelijk:

- de hulp aan bepaalde categorleên van patiënten;

- het benoemen van voorwaardenscheppende of ondersteunende taken, die de hulsarts helpen blj zijn functioneren als hulpverlener;

- taken vanwege de overheid.

Het gevolg van deze werkw1jze is, dat bepaalde taken, zoals de preventle, nlet als aparte 1ngang, maar onder de verschillende hoofdstukken van het takenpakket worden genoemd. Op basis van het gekozen model en van de benadering langs de andere 1ngangen $z 1 j \mathrm{n}$ de basis-taken van de huisarts door de LHV als volgt schematlsch gerangschikt in de volgende hoofdcategorleẹn:

A. Taken, afgeleld van het hulpverleningsproces.

1. Entree-taken: hleronder wordt verstaan dat de huisarts al het nodige doet om open te staan voor alle vragen om hulp, zijn hulpaanbod af te stemmen op de behoeften van de individuele patiënt en daarbij samen te werken met andere hulpverleners.

2. Diagnostische taken, bestaande uit:

- de vraag- en klachtverheldering

- het opstellen van werkhypothesen

3. Taken ten aanzien van het handelingsplan, omvattende:

- het afwljzen van de hulpvraag

- afwachten

- het adviseren van zelfzorg

- het geven van voorlichting en adviezen

- de medicamentueze theraple

- het verrichten van ingrepen

- het gesprek

- de consultatle en de verwijzing

- de begelelding

4. Terugkoppelingstaken, deze omvatten:

- het kritisch bezien van de werkhypothese en de ingestelde behandeling tegen het licht van het beloop van de aandoening, en

- het zo nod $\mathrm{Ig}$ aanpassen daarvan 
B. Taken, afgeleid van bepaalde categorieën van patienten.

1. Zwangeren en pasgeborenen

2. Zuigellngen, kleuters en jeudigen

3. Beroepsbevolking

4. Bejaarden

5. Stervenden

6. Rouwenden

7. Patiënten met een chronische zlekte

8. Patiënten, die acute hulp behoeven

c. Ondersteunende taken.

1. Het ontwikkelen en op pe11 brengen van kennis, vaardigheden en attitude

2. Samenwerking met andere hulpverleners

3. Praktijkorganisatie

4. Medische en financlele organisatie

5. Praktijkuitrusting

D. Overige taken.

1. Taken vanwege de overheld:

- overlijdensverklaringen, aangifte van besmettelijke ziekten, e.d.

- bloedproeven, etc.

2. Signaleren van gezondheidsbelnvloedende factoren

3. Taken ten aanzien van de beroepsorganlsatle:

- actieve deelneming aan activiteiten

- bestuursfuncties, e.d.

4. Taken ten aanzien van de beroepsopleiding tot hulsarts.

In het basis-takenpakket $1 s$ de meest recente visie op de functle van de hulsarts verwerkt. De 21 hoofdcategorleén van taken $z i j n$ onderverdeeld in 216 taken, warin nawweu$\mathrm{r} 1 \mathrm{~g}$ gepreciseerd is wat de hulsarts behoort te doen. D1t omvangrijke rapport "Basis Takenpakket" kan als zodanig "... een rol spelen bij de honorering. In het modelcontract tussen huisarts en ziekenfonds zou het kunnen worden opgenomen, met dien verstande, dat het basis-takkenpakket tenminste de aard en omvang van de hulsartsenhulp aangeeft" (LHV, 1982, Basis Takenpakket, p. 5). 
Wat de schematische indelling van de hoofdcategorleën van taken betreft, $11 j k t$ deze de taakstructuur, die ult de in de vorige paragraaf gerefereerde praktijkanalyses naar voren komt, nabij te komen. De indeling ult het basis-takenpakket is echter toch onvangrijker, met name wat betreft het afwljzen van de hulpvraag, het afwachten en het adviseren van zelfzorg, de taken ten aanzien van de beroepsbevolktng en een aantal categorleèn onder "overige taken", zoals b1jwoorbeeld het signaleren van gezondheidsbelnvloedende factoren. U1t de prakt1jkanalytische onderzoeken komen deze taken minder of niet duldelijk naar voren. Dat kan te maken hebben met het felt, dat deze taken in een lage frequentle voorkomen, of ad hoc worden verricht. Het is begrijpelijk, dat men voor deze activiteiten toch een plaats heeft ingeruimd in een basis-takenpakket, dat bedoeld 18 om te worden ingezet in de diacussle ontrent de bijdrage van de hulsartsgeneeskunde an de gezonhdeidszorg.

2.4. De factoren, die met de taakultoefening van de huisarts samenhangen.

In het 11teratuuroverzicht in paragraaf 2.2 . zijn onderzoeken ter sprake gekomen, waarin melding gemaakt wordt van factoren, die een samenhang vertonen met de taakvervulling van de hulsarts.

Allereerst wordt tijdgebrek, c.q. grote werklast genoemd (Jansen-Emmer, 1958; Van der Wielen, 1960; Huygen, 1965; Oosterhuis, 1972; Boots, 1983). Tifdgebrek hangt nauw samen met de praktijkgrootte. In een grote praktijk worden meer verrichtingen gedaan (Aulbers et al., 1971). Dit maakt, dat niet of onvoldoende aan zaken toegekomen kan worden, die men zou wilen doen of die zouden moeten gebeuren, zowel op het gebled van de curatieve zorg, als de preventle, de begelelding, de nascholing, e.d. Er zijn geen aanwijzingen gevonden dat artsen dle over veel tijd beschikken een andere verdeling in de taakultoefening laten zilen.

De urbanlsatlegraad, c.q. de plaats war gepraktiseerd wordt heeft invloed op verschlllende facetten. Van der Wielen (1960) vond, dat de doeltreffendheid van de door de hulsartsen verleende gezondheldszorg groter was als de prakt 1 Jk gelegen was in een gebied dat overwegend valt te typeren als agrarlsch platteland. In de grote stad zlet de huisarts zijn patienten vaker op het spreekuur. Op het 
platteland legt de hulsarts meer hulsbezoeken af (Bremer en Van Westreenen, 1964; Aulbers et al.; 1971; Rlchardson et al., 1973). In de grote stad is de afstand tot het zlekenhuls klelner, hetgeen de werkwijze van de hulsarts kan beInvloeden, onder andere tot ulting komend in een groter aantal verwijzingen Raupp, 1971; Collaris, 1980). In de steden heeft de huisarts bovendien te maken met concurrentle van medische, ambtelijke instanties, die bijvoorbeeld de zulgelingen- en kleuterzorg naar zlch toe trekken (Bremer en Van Westreenen, 1964).

De aanwezigheid en beschikbaarheid van diagnostlsche faciliteiten kan bijdragen tot een verdleping van de diagnostiek van de huisarts en een betere dienstverlening aan patiënten (Prins, 1976). Als dat gepaard gat met de moge$11 j k h e i d$ van consultatie kan dat van ondersteunende betekenis zijn voor bifvoorbeeld de zorg voor bejaarden (Willemse, 1981; Brouwer, 1982).

Nlet alleen de praktijkgrootte, ook de praktijkvorm kan van betekenis zijn. Solopraktijken blijken een hoger verwijsc1jfer te vertonen (Crebolder, 1977; Collar1s, 1980; Van Duuren en Hupkens, 1981 ).

De demografische kenmerken van de praktijkbevolking (leeftijd, geslacht, soctaal-economlsche status en dergelijke) kunnen verschillen in de zorg en daarmee in de verrichtingen en de taakultoefenling verklaren (0.a. Ruhe, 1957). Zo vinden preventieve contacten vooral plaats met kinderen tot zes jaar en nemen die contacten af naarmate de leeftijd van de patiënten toeneemt (Bremer en Van Westreenen, 1964; Au1bers et al., 1971; Richardson et al., 1973). Bejaarden hebben een hogere consultfrequentie (Schach, Brecht, Schwarz, 1983) en worden vaker thuis bezocht (Aulbers et al., 1971; Knox et al., 1984; Morrell et a1., 1970).

Voor bejaarden worden ook meer medicamenten voorgeschreven (Bremer en Van Westreenen, 1964). Veel jonge gezinnen in de praktijk betekent relatief meer curatleve zorg (kinderzlekten, ongevallen in hulis), meer geboorteregeling, verloskundige zorg (Bremer en Van Westreenen, 1964; Bremer, 1978), of begelelding bif psychosoclale problematiek (Gozin, 1980; Mol1 van Charante, 1978; Huygen, 1968, 1970).

ook de verhouding tussen het aantal ziekenfondspatiènten en particulier verzekerden is van betekenis voor het aantal verrichtingen. Zlekenfondsleden consulteren de hulsarts vaker (Aulbers et a1., 1971; Van de Ven et a1., 1980; Van 
v1let en Van de Ven, 1982). Voor zlekenfondspatienten wordt meer curatlef werk verricht, aan particuller verzekerden wordt meer preventieve zorg verleend. Zliekenfondsverzekerden worden vaker verwezen dan particuller-verzekerden (Van de Ven et 1., 1980; Rop et a1., 1979).

Hulsartsen blljken nogal sterk in werkwijze van elkaar te verschillen, hetgeen $z 1 j n$ invloed heeft op de taakultoefening. Het verwijsgedrag en de verschillen daarin zijn nogal eens beschreven en onderzocht (0.a. De Melker, 1974; Crebolder, 1977; Rop et al., 1979; Verhoef, 1979; Posthuma et 1., 1977).

Gebruik van microblologische onderzoeksfacillteiten van de hulsarts kan helpen om de aanwezigheld van penicililnasevormende pathogenen op te sporen en kan dus een steun zijn b1j de behandeling van infecties (Schade en Wal11g, 1984). Cottaar et al., (1983) vonden ook, dat het gebruik van röntgenfacilitelten een steun blijkt te kunnen zijn bij de dlagnostlek en het behandelingsbeleld van de huisarts en kan helpen het aantal verwijzingen te beperken.

Samenwerken met andere disciplines kan eveneens bijdragen aan het beperken van het aantal verwijzingen en het bevorderen van de thuiszorg (Crebolder, 1977).

Van Staveren (1984) heeft een breed opgezet onderzoek verricht om het verband tussen takkopvatting en werkwijze bij huisartsen na te gaan. Om de taakopvatting te meten zijn zeven taakopvattingschalen voor hulsartsen ontwikkeld. De werkwijze werd gemeten door middel van gedragsobservaties met behulp van gedragsobservatieschema's. De gedragsobservatles zifn ultgevoerd met video-opnames van spreekuurconsulten en transcripten daarvan. In de werkwijze zijn twee dimensies onderschelden:

- een patientgerichte werkwijze: aandacht voor de ind1viduele belevingen en omstandigheden van de patiënt

- een geneeskunde gerichte werkw1jze: aandacht voor het toepassen van geneeskundlge kennis en vaardigheden

Hif vond een positlef verband tussen de taakopvatting, c.q. de attitude van de arts en de werkwijze, dat wil zeggen het gespreks-cotmunicatieve gedrag van de arts tijdens het consult; hoe positiever de attitude ten opzlchte van de persoonsgerichtheld des te meer persoonsgerlchte gedragskenmerken in de werkwijze van de hulsarts; hoe positiever de attltude ten opzichte van de geneeskunde-gerichtheid des te 
meer geneeskunde-gerichte gedragskenmerken in de werkwijze. De persoonlijke houding tegenover het huisarts-zijn en de beroepsbeleving ziljn van invloed op de werkwijze (Van der Wielen, 1960; Raupp, 1971). Een meer onafhankelljke taakopvatting kan bijdragen, aan een versterking van de eerste $11 \mathrm{jn}$, omdat die hulsartsen sterker geneigd zijn zelf meer dingen te doen (Dophelde, 1980; Bremer, 1978; Huygen, 1965). Het bezoek van patienten in het ziekenhuls en het zich daadwerkelijk voor die patiënten verantwoordelijk blijven voelen hangt onder andere samen met de taakopvatting (Jacobs et al., 1979).

Tenslotte speelt de leeftijd van de arts een rol. Oudere artsen leggen meer visites af en doen meer verrichtingen (Raupp, 1971; Richardson et a1., 1973).

Samenvattend.

Uit dit 11teraturoverzicht naar de factoren, die van invloed zijn op de taakuitoefening blijkt dat die factoren schematisch als volgt te rangschikken zijn in factoren betrekking hebbend op:

- de werksituatie

- de werkwijze

- de persoon van de huisarts

Tot de werksituatie van de hulsarts kunnen de volgende factoren gerekend worden:

- de praktijkgrootte

- de prakt1jkvorm

- de verhouding zlekenfonds-particulier verzekerden

- het patiëntenaanbod = het gemiddeld aantal patienten per uur

- de beschikbare tijd

- de aanwezigheid en beschikbaarheld van gezondhelds zorgvoorzleningen; bijvoorbeeld consultatie van speclalisten

- de urbanisatiegraad van de gemeente van vestiging - de demografische kenmerken van de prakt1jkbevolking

- de afstand tot het zlekenhuis

Onder de werkwijzekenmerken van de hulsartsen ressorteren o.a. de volgende factoren:

- het gebrulk van diagnostische voorzleningen in het 


\author{
zlekenhuis \\ - de frequentie van verwijzen \\ - het gebruik van instrumentarium \\ - de gemiddelde consultduur
}

Kenmerken die betrekking hebben op de persoon van de arts zijn o.a.:

- de leefijd van de hulsarts of de mate van prakt1jkervaring van de hulsarts

- de taakopvatting van de hulsarts

- de bereldheld on met anderen samen te werken

- het vermogen om met onzekerheden te leven.

Vrijwel alle bovenstaande factoren zijn ook in mijn onderzoek betrokken. 
Hoofdstuk 3. De observatlemethode.

3.1. Inle1ding.

Bif de probleem- en vraagstelling aan het elnde van hoofdstuk 1 is vermeld, dat het onderzoek, waarvan hier verslag wordt gedaan, een observatie-onderzoek is. Hulsartsen zijn In hun dagelijkse bezigheden door ons geobserveerd. Daar was een observatie-instrument voor nodig. Dat meetinstrument was niet pas-klaar voorhanden, maar moest eerst door mif ontwikkeld worden. Reeds dit feit geeft aan het onderzoek een exploratief karakter.

Allereerst is in de 11 teratuur gezocht naar de theoretische uitgangspunten van de methode van observatie en naar de criteria en eisen, die men aan een systeen van observatiecategorieën moet stellen, wil men met het instrument valide en betrouwbare metingen kunnen verrichten. Dat 11teratuuronderzoek en de wijze, waarop wij aan de nodige criteria en elsen hebben trachten te beantwoorden bij de constructie van het meetinstrument wordt behandeld in paragraaf 3.2 . Het observatie-1nstrument wordt beschreven in 3.3 . De indeling en de Inhoud van de observatie-categorleën worden behandeld in 3.4. Het onderzoek naar de geldigheid en de betrouwbaarheid van de observatie is beschreven in 3.5. De representativiteit van de observaties komt aan de orde in 3.6. In 3.7 . volgt een beschrijuing van de toepassing van het meetinstrument. Het hoofdstuk eindigt met een samenvatting in 3.8 .

3.2.1. De theoretische uitgangspunten voor de methode van observatie.

Er is een aantal terreinen, dat zich bij ultstek leent voor observatie:

Wanneer men wil nagaan wat mensen in het kader van bepaalde functies of taken feitel1jk doen, 18 observatie een goed bruikbare methode, met name wanneer dle mensen door de elsen van de situatle zo in beslag genomen worden, dat $z 1 \mathrm{f}$ zich achteraf geen nauwkeur $1 \mathrm{~g}$ beeld meer kunnen vormen hoe zij daadwerkelijk gehandeld hebben, bijvoorbeeld buschauffeurs, trelnbestuurders. Wanneer men zaken onderzoekt, die mensen zlch liever niet meer willen herinneren. In de observatiestudie 
van Relss (1971) betreffeade de contacten van het publlek met de polltle bleek, dat bijna vier van de tien burgers hun contacten met de politle "vergeten" waren. - Blj onderzoek van handelingen of gedraglngen, die maatschappel1jk of normatief gevoellg 11ggen, bijvoorbeeld onderzoek naar rassendiscriminatie. In die gevallen bestaat vaak een discrepantie tussen wat mensen zeggen te doen en wat ze werkel1jk doen.

In al deze gevallen, die overigen nog met vele kunnen worden aangevuld, is observatie een mogelifkheld om het gedrag van actoren te bestuderen.

Wat houdt observatle in? Welck (1968) geeft hiervoor de volgende definitie:

"De methode van observatie kan gedefiniëerd worden als de selectle, de ultlokking, de registratie en de codering van die verzameling van gedragingen en situaties, die betrekking heeft op organlsmen (mensen, dieren) "In situ" (hun natuurlijke omgeving), die overeenkomt met emplrische doelelnden". Observatie van gedrag of handelen vindt dan plaats aan de hand van selectle, uitlokking, registratie en codering.

"Selectie" wil zeggen het maken van keuzen. Niet alles kan en behoeft te worden waargenomen. Zowel v66r als tijdens de observatieperiode zal men moeten kiezen wat wargenomen moet worden. "Uitlokking" kan soms nodig zijn, als gebeurtenissen weinig of verspreid voorkomen. Door subtiele aanwijzigingen kan de gebeurtents in de natuurlijke situatie van de geobserveerde worden opgeroepen. Veenman (1975) heeft, in $\mathbf{1} \mathfrak{J n}$ onderzoek over de interakties $\mathbb{1 n}$ de schoo1klas, dit toegepast.

Voor observatie-onderzoek is "reglstratle" van gebeurtenissen of handelingen nodig teneinde ze later te kunnen analyseren. Dat reglstreren kan op velerle1 wijze gedaan worden, bljvoorbeeld met video-opnames, processen-verbaal, dagboeken, of scoring door observatoren.

Met het "coderen" wordt ordening gebracht in de registraties. Dat kan gebeuren door te classificeren in categorieen, door het tellen van handelingen of gebeurtenissen of het toekennen van waarderingen in een schaal.

Met "verzameling van gedragingen en sltuatles" wordt bedoeld dat bepalde gebeurtenissen of gedragingen op meerdere tijdstippen voorkomen en als zodanig op die tijdstippen 
moeten worden geobserveerd. Bij het taakanalytisch vaststellen van de taakomvang zal het in de observatie nodig $z 1 \mathrm{jn}$, dat de verschillende taakonderdelen bif herhaling in verschillende situaties en tifdstippen worden geregistreerd. Door een weldoordachte keuze van die situaties en t1jdstippen kunnen de betrouwbaarheld en de geldigheld worden vergroot. Zo verdient het bljyoorbeeld aanbeveling niet telkens op de zelfde dag en op het zelfde tijdstip te observeren, maar de observaties te spreiden over de dagen van de week.

Met "empirische doeleinden" wordt aangegeven dat een observatlestudle voor verschillende doeleinden kan dienen: zoals het geven van een beschrijuing, het formuleren of toetsen van hypothesen. Want observatle is voor een onderzoeker een middel om zijn doel te bereiken.

\subsubsection{Vormen van observatles.}

Er zijn verschillende vormen van observaties te onderscheiden. De voornaamste zijn: niet-participerend en participerend. Belde kunnen toegepast worden met een vooraf nauwkeurig gedefinlëerd waarnemingsinstrument (systematische observatie) of zonder een vooraf opgesteld schema (niet-systematische observatie). Bif de niet-systematische observatie zal de observator de gedragingen, die hij observeert interpreteren in een theoretisch kader; bijvoorbeeld bij ethologisch onderzoek is dit vaak het geval. Bij een nietparticlperende observatie heeft de observator geen deel aan de te observeren activitelten. Bij participerende observatle woont de observator de te observeren situatle bij door daarin een bepaalde rol te vervullen, bifvoorbeeld in een groepsproces. H1j bestudeert dan de waarden, normen en gedragingen van de groep "van binnen ult".

In ons onderzoek is gebrulk gemakt van een systematische, nlet-participerende observatie.

3.2.3. Soorten van observatle-1nstrumenten.

In geval van systemat $18 \mathrm{che}$ observatie voert de observator de observatle ult aan de hand van een handelingsvoorschrlft om de handelingen, die hij ziet gebeuren, te classificeren. De observator heeft dus een observatie-instrument nodig. Dat kan bestaan uit een tekensysteem, dat w11 zeggen dat op 
een formuller aangekrulst moet worden of een handeling in een vooraf gespecificeerde tijdseenheld al of niet is voorgekomen. Deze methode is door ons gebrulkt in het proefonderzoek (Boots, 1983).

B1j gebrulk van een categorleënsysteem moet de observator telkens wanneer een bepaalde handelling optreedt reglstreren onder cen van de categorieën. die tesamen het handelingsinstrument vormen. Met deze reglstratle blifft de sequentle in de handelingen behouden. Het meetniveau is in dit geval nominaal van karakter.

Het handelingsinstrument kan ook bestaan ult een waarderingsschaal. Door de observator wordt dan na afloop van de observatle een schatting gemaakt hoe vaak bepaalde gedragingen of gebeurtenissen $z 1 j n$ voorgekomen of er wordt aan ledere persoon of gebeurtenis ult het geobserveerde groepsof handelingsproces een bepaalde waarde toegekend, bijvoorbeeld op een vijfpuntsschaal. Het meetniveau is dan ordinaal.

In ons onderzoek 1 s het meetniveau van nominaal karakter. De geobserveerde handelingen zijn zowel naar frequentle van voorkomen als naar tijdsduur gereglstreerd telkens onder cen van de categorleèn van het handelings- of abservatieinst rument.

3.2.4. De achtergrond voor het opotellen van een warnemingssysteem, met name een categorleèn-systeem.

Aan de basis van een waarnemings - of reglstratiesysteem dlent een probleem- of vraagstelling te 11 ggen. Een theoret1sch kader of concept is noodzakelijk. Zonder dat kan niet serleus geevalueerd worden. De gegevens zijn dan nlet echt bruikbaar voor onderzoek. Men komt dan nlet verder dan het sprokkelen van felten (De Vries, 1977; PhIlipsen, 1973). Om bepaalde verschijnselen te kunnen waarnemen en evalueren is een probleemstelling of een theoretisch kader dus onmisbaar. In ons onderzoek $1 \mathrm{~s}$ zo'n probleemstelling duidelijk aanwe $z 1 \mathrm{~g}$ en heeft betrekking op het vinden van achterliggende dimensies in de dage11jkse werkzaamheden van hulsartgen en van verklaringen voor verschillen in taakuitoefening $(z 1 \mathrm{e} 1.2$.$) .$ 
3.2.5. Selectle van warnemingselementen on classifficeren van het waargenomen mogell jk te maken.

Waarnemen houdt selectie in. Een keuze zal gemaakt moeten worden:

a. ten aanzien van die delen uit de continue stroom van gedrag, of verschijnselen of handelingen, die voor de probleemstelling relevant $z i j n$, en

b. ten aanzien van passende waarnemingselementen, die een classificatie van de waarnemingen mogell jk maken.

Een waarnemingselement is een standaardeenheld van observatie, die door de observator als zodanig gecodeerd wordt. Een waarnemingselement kan Identiek zijn aan de observatiecategorie, maar dat behoeft niet.

De observatiecategorieën zijn de operationele definities van de elgenschappen of aspecten van het onderwerp van onderzoek, met andere woorden de operationele definities van de variabelen. De waarnemingselementen of, als die identiek zijn aan de observatiecategorieën, de observatlecategorleën zijn, al of niet gespeciflceerd naar tijdsduur of frequentie van voorkomen, de analyse-eenheden van het onderzoek. Dat wil zeggen de analyse-eenheden vormen de gegevens, die na verwerking de uitkomsten van het onderzoek opleveren.

\subsubsection{Het ontwerpen van een observatie-instrument.}

Hiervoor staan in feite twee wegen open. De ene benadering is de rationele, ook wel deductieve weg, de andere de emplrische of inductieve weg.

Bij de empirlsche benadering wordt pas in tweede instantie, dat w11 zeggen na de concrete warneming, een observatieinstrument ontwikkeld om de verschijnselen te classificeren. Een theoretlsch kader of een bepaald concept 18 dus vooraf niet aanwezig. In het algemeen gesproken is dat riskant, want een beschrijving in wetenschappelijke zin is aan een theorle gekoppeld en veronderstelt klezen, ordenen, abstraheren. De werkelijkheld kan nlet onvooringenomen tegemoet getreden worden (De Vries, 1977). Soms is het echter niet mogelifk om van te voren een theoretisch kader of een concept te ontwikkelen en zal men niet anders dan van de empirische benadering gebruik kunnen maken.

Bij de rationele benadering gat men uit van een bepald 
concept, model of theoret1sch kader om de te onderzoeken aspecten van het onderzoekselement te operationaliseren en te definlèren In observatiecategorieẻn. Daarna zal het observatie-instrument getoetst moeten worden aan de werke$11 j k h e 1 d$, an de felten. Dit gebeurt in een vooronderzoek. Anders verkiljgt men geen relevante en zinvolle categorieen. Aan het opstellen van die observatlecategorleen zijn een antal elsen te stellen. Matgevend $z 1 j n$ in de eerste plaats de probleemstelling en het onderwerp van onderzoek. Herbert en Attridge (1975) geven voor ons geval vanult een behavlouristische benadering een vijftal brulkbare criteria voor het opstellen van observatlecategorleèn. Brulkbaar, omdat het in ons onderzoek gaat, zoals we nog zullen zien, om het registreren van het handelen en de intenties daarbij van hulsartsen in hun dagelijkse doen. Dle criteria zijn:

a. een heldere en ondubbelzlnnige omschrijving van de handelingen en gedraglingen in kwestle;

b. consistentie met het onderliggende concept of theorie;

c. de dimensies van het onderzochte gedrag of de handelingen moeten volledlg gedekt $21 j n$;

d. de categorieèn moeten representatief $z 1 \mathrm{fn}$, dat wil zeggen dat de Inhoud van de categorleün valide gedef1nlëerd moet zljn zodat senduldig gescoord kan worden:

e. de categorieên dienen elkaar wederzljds uit te sluiten.

In ons onderzoek zijn als observatiecategorleèn activiteiten gespecificeerd, die grotendeels samenvallen met de taakomschrijving uit het rapport: "De taken van de huisarts" van de Comissie Takenpakket van de LHV (LHV, 1977). De basis voor deze taakopsomming werd gevonden in de taak1ndeling in hoofdstuk 3 van de discussienota van de Commissle Eerste Echelon van de kNMG ("Huisarts waarheen?", Med1sch Contact, 1976, nr. 5, p. 14 e.v.). Daarnaast is gebrulk gemaakt van elementen ult de onderwijsnota van het Utrechts Unlversttalr Hulsartsen Inst1tuut: "Kenmerken van de hulsarts" (Utrecht, 1975), van het NHG-rapport: "Hoe helpt de dokter?" (NHG, 1975) en van de eerste uitgave van de "Blauwdruk" van het Centraal Bestuur van de LHV (LHV, 1975). Met andere woorden de taakopsoming in het rapport "De Taken van de Hulsarts" is het resultaat van een uitgebrelde reflectle op een discussie, die heeft plaatsgevonden zowel in de schoot van de beroepsgroep van hulsartsen (LHV en UUHI) als in het bredere forum van de Nederlandse arts- 
enstand binnen de KNMG. Op grond daarvan zijn wij er van ultgegaan, dat door het categorleensysteem te baseren op de genoemde taakomschrijuing, voldaan is an het criterium voor een theoretisch kader of een bepald consistent concept. Vervolgens is het aldus opgestelde categorleënsysteem getoetst op zijn toepasbaarheid in een proefonderzoek. Zo werden relevante en zinvolle categorieẹn verkregen en een heldere en ondubbelzinnige omschrijuing van de handelingen in kwestie. Met het proefonderzoek is er voor gezorgd dat de intentles van de handelingen van de huisartsen volledig gedekt waren, door na te gaan, of de categorieën vallde gedefinlëerd waren. In besprekingen tussen de observatoren ult het proefonderzoek zijn dle definities, waar nodig, bljgesteld, waardoor tenslotte eénduldig gescoord kon worden. In het definitieve onderzoek is voor dit doel bovendien een viertal bijeenkomsten met de observatoren belegd teneinde de unanimiteit in scoring zo hoog nogelijk te krijgen. Ten aanzien van enkele, weinlg voorkomende handelingen zijn toen de definities enkele categorleën nog wat aangevuld, zodat het onderzoek tenslotte uitgevoerd is met observatie-categorleën, die elkaar wederzijds uisluiten.

Een ander aandachtspunt bij het ontwerpen van categorieën is de toegestane interpretatierulmte voor de observatoren. Dit punt is belangrijk voor ons onderzoek, omdat hierin intenties van handeling, die uit die handelingen $z i \mathrm{fn}$ af te leiden, gescoord moeten worden. Bij het ontwerpen van een observatie-instrument is het dus noodzakelijk aan te geven warop de observatie gericht is: de intenties van de handelingen, de objectieve kenmerken daarvan of de functies van de handelingen. Om te contrôleren of in ons onderzoek de observatoren ook daadwerkelijk binnen de toegestane interpretatleruimte bleven, werden tijdens de genoende vier bijeenkomsten ook videobanden van spreekuurconsulten getoond. Deze consulten werden geobserveerd en gescoord door de observatoren en de schrijver dezes. Die observatles zijn met elkaar vergeleken, waarbij mijn scoring als "judge-score" fungeerde. Hiermee werd als het ware een "continue" instructle van de observatoren berelkt. De resultaten van die vergelijken $z i j n$ verderop vermeld ( $\operatorname{par}$. 4.6.).

Bij het ontwerpen van een observatie-1nstrument zal tenslotte besloten moeten worden hoe de codering zal plaatsvinden: enkelvoudig of meervoudig. Meervoudig wil zeggen 
dat meerdere categorieën tegelljkertijd, als een combinatle, gescoord worden. In dit onderzoek ben lk in principe ultgegaan van een enkelvoudige codering. Er kunnen zich echter situaties voordoen, dat een hulsarts twee of meer dingen tegelijk doet. Het komt bijvoorbeeld voor dat een arts bezlg $1 \mathrm{~s}$ met 1 lchamelljk onderzoek en aan de patiënt tegel1jk nog wat anamestische vragen stelt. In die gevallen kon een combinatie van die handelingen gecodeerd worden. Comblnaties betroffen altijd handelingen die tot efn taak behoren: in het gegeven voorbeeld betreft het de dlagnostiek. Zou de hulsarts gellfkertijd bijvoorbeeld preventie en theraple combineren dan werd alleen datgene gecodeerd waarop in termen van intentie het accent 1 ag en werd er dus enkelvoudig gecodeerd. Overigens zijn deze comblnaties in de gegevens niet verder bewerkt. We hebben afgezten van een patroonanalyse in het handelen van hulsartsen.

\section{2 .2 . Soorten van warnemingselementen.}

Standaardeenheden van observatle kunnen worden ingevuld naar hun specificatte van tifdsinterval van registratie. Zo onderschelden we: continue waarneming, time-sampling waarbij de tijdsintervallen relatief groot $z i j n$, in feite een vorm van steekproef trekken. Indien de te observeren verschijnselen niet in gefixeerde tijdsintervallen of in timesamples te vatten $z 1 j n$, kan men gebruik maken van zogenaamde natuur11jke waarnemlngseenheden of event-sampling, waarbij men codeert op het moment van een natuur $11 j k$ breekpunt in de handeling, bijvoorbeeld agressieve momenten in een voetbalwedstrijd.

Ons onderzoek is ultgevoerd als een continue registratie, omdat het tijdsinterval van reglstratie, namel1jk om de 10 seconden, zodanis kleln is, dat nitet gesproken kan worden van "mult1-moment-opnamen" (Blokland-Kühler, 1974).

Tenslotte zal men de warnemingselementen moeten indelen in analytische eenheden om in de analyse verwerkt te kunnen worden. Deze eenheden worden theoretisch gedefiniëerd en behoeven zlch geenszins te beperken tot losse handelingen. Ze kunnen ook gedefinlëerd worden naar eenheden, sequenties of patronen van handelingen.

Door de omvorming naar analytische eenheden krijgen de warnemingseenheden pas hun daadwerkelifke, in een theoretisch kader Ingebedde, betekenis. Betreft het, zoals in ons 
geval, een frequentie-tijdobservatie met gedefinieêrde categorieën dan kan men per observatle-categorle de absolute of relatieve frequentie of tijdsduur berekenen. Van alle observatie-categorleën hebben wij de relatieve tijdsduur berekend, dat wil zeggen, dat we van ledere hulsarts de totaal wargenomen tijdsbesteding aan leder van de observatiecategorieën uitgedrukt hebben in een percentage van $z i j n$ of haar totaal geobserveerde t1jd. Die percentages vormen onze analyse-eenheden. Van enkele handelingen of verrichtingen, met name van de verwijzingen, het eigen en het uitbestede laboratorlumonderzoek en de medicaties, is het aantal per honderd arts-patient contacten berekend (proporties) en als analyse-eenheden gebruikt.

\subsubsection{Factoren, die de waarneming belnvloeden.}

De voornaamste bron van fouten bij observaties $1 \mathrm{kgt}$ bij de observator. Enerzifds kunnen die fouten voortkomen uit het felt dat de observator afgeleld wordt of vermoeld raakt. Anderzijds kan de observator ten opzichte van het geobserveerde bevooroordeeld $z 1 j n$, te veel vrljheld nemen in de interpretatie van het gebeuren of als met meerdere observatoren gewerkt wordt, kan per observator de opvatting over zijn taak verschillend zijn. Opleiding en achtergrond van de observatoren spelen eveneens een grote rol. Veel van deze fouten kunnen voorkomen of tot een minimum ingeperkt worden door een zorgvuldige selectle van observatoren (op deskundigheid bijvoorbeeld) en door een grondige training In het hanteren van het observatie-instrument.

Om de vermoeidheid of verlies van andacht bif de observatoren zo veel mogel1jk te beperken hebben wij besloten om hen maximal een halve dag achtereen te laten observeren. Bovendien hebben we gewerkt met inhoudsdeskundige observatoren. Allen waren (huis-)arts. Ze hadden voor het onderzoek een 1ntensieve training ondergaan. (waarover later meer) en $z i j$ hadden $t \mathbb{1 j d e n s}$ de observaties een 1 in een handig format afgedrukte observatie-instructie bij zich.

Een andere bron van fouten in de waarneming kan gelegen zijn in de tijdstippen warop de observatie heeft plaats gehad of de t1jd gedurende welke geobserveerd 1s. Voor arbeids- en talkanalyse bifvoorbeeld is het belangrijk dat men de observatle op verschillende werkdagen, gedurende een voldoende lange tijd en onder diverse omstandigheden laat 
plaatsvinden om werkelijk alle facetten van het werk of de takkultoefening te kunnen meten.

In ons onderzoek hadden de observatoren de opdracht om iedere hulsarts gedurende ongeveer 20 uur in sen week te observeren en die observaties zoveel mogelljk over die week te spreiden. Die observaties moesten onder vier rubrieken gereglstreerd worden, te weten: vrij spreekuur, afspraakspreekuur, visites en niet-patiënt gebonden tifd (overige omstandigheden).

\subsubsection{Methode van trainlag.}

Het trainen van observatoren is dus een zeer belangrijke zaak. Heyns en Zander (1966) bevelen daarbij de volgende procedure aan:

- het vertrouwd maken van de observator(en) met het theoretisch kader en het doel van het onderzoek;

- het introduceren van het observatie-instrument, met dulde1ljke uitleg en discussie;

- het laten oefenen met het observatie-instrument, bijvoorbeeld aan de hand van video-opnames;

- de met het proefdraalen opgedane ervaringen ultvoerig bespreken en de reglstraties onderling vergel1jken, waarbij aanvullende observatieregels kunnen worden opgesteld;

- zo mogelifk het observatie-instrument en het gebrulk van de registratie-apparatuur laten oefenen;

- de objectivitelt van de observatles vastleggen door middel van betrouwbaarheldsmetingen.

Als criterium voor de objectivitelt wordt algemeen intersubjectleve overeensteming tussen de observatoren en de opsteller van het categorieënsysteem aangehouden. Dat is ook In ons onderzoek gebeurd tijdens de al eerder genoemde bijeenkomsten en in de tralning. T1jdens die trainlng is de bovenstaande procedure exact gevolgd en is aan alle daarbij genoemde punten uitvoerig aandacht besteed.

Belangrijk is ook dat de onderzoekers het probleem van de introductle van de observatoren in de onderzoekssituatie aan de orde stellen. Vooral in niet-particlperende observatles geldt, dat de rol van de observator(en) aan de geobserveerde( $n$ ) duldel1jk gemaakt moet worden. Dit is door ons gebeurd, zowel naar de artsen toe, als naar de patienten. In bijeenkomsten met de particlperende hulsartsen is het 
doel van de observatie en de rol van de observatoren duldelijk gemaakt.

3.3.5. De invloed van de observator.

Met de rol van de observator zal tegelijkertijd de interaktie tussen observator en geobserveerde in ogenschouw moeten worden genomen. Men dient na te gaan welke mogelifke vertekeningen er in de te observeren situatie door de aanwezigheld van de observator kunnen ontstaan en hoe die kunnen worden opgevangen, ook al wordt er in het algemeen van ultgegaan dat de geobserveerde de aanwezigheid snel zal vergeten omdat de actor spoedig geheel door de werksituatie in beslag zal zijn genomen of an die aanwezigheld gewend raakt en zich in zijn doen en laten niet laat belnvloeden. In sommige gevallen zal het gebrulk van bijvoorbeeld een one-way screen een goede uftkomst bieden. Doch ten principale zal men er altijd goed aan doen ten opzlchte van de geobserveerden opening van zaken te verschaffen in de $z i n$, dat de observator precies uitlegt wat het doel van de observatie is. Zoals gezegd is dat hier gebeurd. Of ex desondanks geen vertekening is opgetreden is moellijk met zekerheid te zeggen. Uit eigen ervaring en uit opmerkingen tijdens de ultvoering van de observaties hebben we stellig de indruk gekregen, dat die vertekening zeer gering is te achten. De patiënten werden op door ons verstrekte affliches in de wachtkamer op de hoogte gebracht, dat er een arts-observator (met vermelding van de naam) in de praktijk aanwezig was ten behoeve van wetenschappelijk onderzoek. Indien $z 1 j$ hun hulsarts alleen wilden spreken, werden $z 1 j$ verzocht dit aan de assistente bekend te maken. Tijdens huisbezoek werd gevraagd of de observator daarbij aanwezig mocht $z \mathbb{L} \mathrm{j}$.

\subsubsection{De technische hulpmiddelen bij de observatie.}

De nauwkeurlgheld van observaties kan verhoogd worden door het de observator in zijn werk zo gemakkelijk moge11jk te maken. Men kan zijn taak aanzienlijk verlichten door hem de julste technische hulpmiddelen aan te bieden. Zo kan men de observator voor het coderen gebrulk laten maken van electronlsche apparatuur in plaats van hem schrljfwerk te laten verrichten op formulieren. In ons onderzoek hebben wij daarvoor speciale apparatuur laten ontwerpen in de vorm van 
een gedrags-observat1e-registrator (G.0.R., Boots, 1980).

\section{Samenvattend:}

Aan de hand van een theoretisch overzicht, ontleend aan een rapport van Veenman (1975) heb ik de criterla en elsen besproken, waraan een observatie-instrument en met name een systeem van observatle-categorieën moet voldoen. In dit observat1e-onderzoek is gebruik gemaakt van een systematische, nlet-participerende observatie met continue registratie door getrainde (hulsarts-)observatoren. Bij die genoemde criterla heb ik de wijze, warop wij aan die criterla hebben trachten te beantwoorden, toegelicht. Thans kom $1 \mathrm{k}$ toe aan de inhoudelijke beschrijulng en de indeling van het observatle-instrument.

\subsection{De observatlecategorleèn.}

Allereerst moeten we aandacht besteden aan een aantal practische moellijkheden die ontstaan bif het ontwerpen van een observatie-instrument ter reglstratle van de dagelijkse werkzaamheden van een huisarts. Een hulsarts verricht veel schijnbaar gelljksooxtlge handelingen, die slechts met kennis van zaken te onderschelden en in te delen zijn, afhankelljk van het doel dat met de handelingen wordt beoogd. Dat is het doel van onze gegevensverzameling; we willen weten welke taken de huisarts uitvoert. Een taak is te definiëren als een verzameling van handelingen, waarmee men een bepaald onschreven doel wil berelken, bijvoorbeeld diagnostlek van nfeuwe klachten, bewaking van risicopatiënten, primalre preventie. Blj onze observatie gat het er niet om allerlel afzonderiljke handelingen te reglstreren, maar om die handelingen te plaatsen in het kader van de taak, dle daarmee beoogd wordt. De handellngen moeten gecodeerd worden binnen een taakcategorie. Die schijnbare gel1jksoortigheld van handelingen is aan de hand van een antal voorbeelden gemakkelijk toe te 1 lichten. Men kan een hulsarts per dag diverse malen zlen schrljven. De ene keer Is dat bedoeld om een recept ult te schrijven, de andere keer gaat het om het Invullen van een verwijskaart of een laboratorlumbrlefje, maar het kan ook zijn, dat hij de klachten of de onderzoeksbevindingen vastlegt op de patiëntenkaart. De administratieve activiteiten uit dit voorbeeld 
zijn achtereenvolgens te classiftceren als een therapeutische bezigheid (recept), een verwijsactivitelt (verwijskaart), een diagnostische handeling (laboratorlumbriefje), of als reglstratie-werkzaamheden (patiëntenkaart).

Vaak zal men de huisarts een injectlespuit zien hanteren met telkens wisselende bedoelingen en daarmee telkens binnen het kader van een andere taak, bljwoorbeeld om lemand te vaccineren tegen griep (preventie), om local anaesthesie te geven voor een kleine chirurgische ingreep (behandeling) of om een bloedmonster te verkrijgen om de bezinkingssnelheld van de erythrocyten te bepalen (diagnostlek). Hiermee is wel duidelijk geworden, dat men blj het registreren en coderen van het huisartsgeneeskundig handelen de diverse afzonderlijke handelingen moet platisen in de context, waarbinnen de geobserveerde arts ze bedoelde te verrichten. Dit betekent onvermijdelijk interpretatie. Om interpretatiefouten zoveel mogelijk te voorkomen moeten we gebruik maken van arts-observatoren, die zelf hulsarts zijn of geweest zijn en dus ervaring en inzicht hebben in het werk van huisartsen.

Het inschakelen van huisarts-observatoren heeft bovendien het voordeel, dat $\mathrm{zij}$ zowel voor de te observeren huisartsen als voor de patiënten eerder aanvaardbaar zijn om het patiënt-arts contact bij te wonen dan "leken-observatoren". Om die reden hebben wif in dit onderzoek met huisarts-observatoren gewerkt.

Het systeem van observatie-categorieën zal noodzakelijkerwijs gebaseerd moeten zijn op een schema of een concept van de taken van de huisarts. Wanneer dat schema strookt met de inzichten van de hulsartsen ten aanzien van hun taken, dan maakt dat het systeem van observatie-categorieen in principe valide. De referenties voor dat concept zijn ontleend aan het rapport: "De Taken van de Hulsarts" (LHV, 1977). Dit rapport heeft in de achterban veel aanlelding gegeven tot discussie. Toch is het rapport "De Taken van de Huisarts" door het Centraal Bestuur van de Landelijke Hulsartsen Vereniging als LHV-rapport geaccepteerd. Het rapport geeft een gedetallleerde normstelling voor de veelheld van werkzaamheden welke door de hulsarts wordt verricht (Medisch Contact, 1977, 32, p. 765).

In dit rapport worden de volgende taken van de hulsarts genoemd:

a. diagnostlek; 
b. theraple;

c. samenwerking met andere hulpverleners in het eerste echelon en ult de andere echelons;

d. kwaliteitsbewaking, door nascholing en (intercollegiale) toetsing:

e. verwijzen, zowel naar specialisten als naar hulpverleners binnen het eerste echelon of buiten de gezondheldszorg;

f. advisering ten aanzlen van werkhervatting;

g. anticiperende geneeskunde en individuele preventie;

h. Informatleverstrekking aan patiënten en aan speciallsten;

1. prakt1jkorganisatie en reglstratie.

Aan de hand hlervan en ondersteund door de ervaringen uit het proefonderzoek heb $1 \mathrm{k}$ ons observatie-instrument ingedeeld naar de volgende taak-categorieën:

1. dlagnostiek;

2. therapie;

3. verwijzen binnen de gezondheidszorg;

4. verwijzen bulten de gezondheldszorg;

5. begelelding van chronische zleken, bejaarden, gehandicapten enz.;

6. preventie;

7. ondersteunende werkzaamheden voor de praktijkvoering en de taakvervulling;

8. (neven)werkzaamheden als arts.

Deze Indeling is bedoeld om het handelen van hulsartsen te kunnen registreren.

Om methodologische redenen is er van afgezien daar ook het probleem- en klachtenaanbod bij te betrekken. Dat is de reden waarom in dit systeem geen specificaties zijn opgenomen wat betreft de patient-arts contacten in de zin van bijvoorbeeld eerste consulten, herhallngsconsulten, enz.

De eerste vier categorieën vormen de specificatie van de Intercurrente zorg, wartoe ook gerekend worden de informatleverstrekking aan patiènten en speclalisten, de therapeutische adviezen en adviezen ten aanzien van werkhervatting. De zorg dle betrekking heeft op langdurlge aandoenlingen is ondergebracht onder de categorie: begeleiding.

De preventie-activiteiten in al zijn vormen zijn gegroepeerd onder de categorie: preventie. 
De taken samenwerking in de hulpwerlening en met andere $d 1-$ sciplines, kwaliteltsbewaking, praktijkorganlsatie en registratie zijn gerangschikt onder: ondersteunende werkzaamheden voor de praktijkvoering en de taakvervuliling.

Een aantal rest-taken, door de LHV en de KNMG-commlssie (KMMG, 1975) gekarakteriseerd respectievelijk als facultatieve of oneigenlijke taken, betreffen werkzaamheden die uit hoofde van het arts-zijn onder andere door huisartsen verricht kunnen worden. Deze heb $1 \mathrm{k}$ gerangschlkt onder: activiteiten als arts.

De definiëring van de taken en de operatlonalisering in (sub)categorieën voor observatie is als volgt:

\section{Diagnostiek:}

Hiertoe worden gerekend alle activiteiten, die er toe moeten lelden, dat de huisarts de gepresenteerde klachten of problemen in meer of mindere mate kan verduldelijken, zodat er een handelwijze kan volgen, door hemzelf of een andere hulpverlener, die gericht is op het verhelpen of verzachten van de veronderstelde aandoening(en).

Het resultaat van de diagnostlek kan de vorm aannemen van een diagnose, een differentiaal diagnose, een werkhypothese of een probleemformulering.

Tot de dlagnostlek behoren de volgende categorleën:

- anamnese;

- 11chamelijk onderzoek;

- elgen laboratorium onderzoek;

- ultbesteed laboratorium onderzoek;

- uitbestede diagnostische bepalingen (röntgenfoto's, e.c.g., enz.).

\section{Therapie:}

Betreft de activiteiten, die tot doel hebben het gediagnostiseerde 11 jden of aandoening te verhelpen of te verzachten; verder het gespreksmatig analyseren van gesignaleerde problemen ter verlichting van een situatie, dile als te belastend wordt ervaren.

Hlertoe behoren de volgende categorieën:

- medicamenteuze therapie;

- advies;

- therapeutische handeling;

- gesprek; 
- het lelden van bevallingen.

We hebben geen aparte categorie: verloskundige zorg, omdat lang niet alle hulsartsen verloskundige zorg verlenen. Het leiden van bevallingen 18 daarom arbitrair ondergebracht onder de categorle: theraple.

De zwangerschapsbegelelding en de zorg om het kraambed zijn door mij gedefinieèrd als pre- en perinatale zorg en ondergebracht onder de categorle: preventie.

Verwijzen binnen de gezondheidszorg:

Hleronder versta $1 \mathrm{k}$ alle handelingen voor het tot stand brengen van contacten met andere hulpverleners in de gezondheidszorg ten behoeve van de Individuele patiëntenzorg met als doel gerlchte diagnostiek en behandeling.

Het kan voorkomen, dat in sommige gevallen de hulsarts een patiënt naar de speclalist verwijst om een diagnose bevestigd te krijgen. Daarom heb ik hier een onderscheld gemaakt in (overwegend) diagnostische en therapeutische verwijzingen. De geestelijke gezondheidszorg wordt tot de gezondheldszorg gerekend.

De huisarts zal nlet in alle gevallen een patiënt overdragen aan een specialist. Soms wordt volstaan met een eenma$11 \mathrm{~g}$ consult, waarbij de speclalist de patiënt wel te zien krijgt $6 f$ met een consultatle, dat wil zeggen een overleg met een speclalist, bijvoorbeeld met betrekking tot de keuze van een bepaalde therapie, zonder dat de specialist de patiënt zelf ziet. De huisarts kan ook als consultgever optreden bifvoorbeeld ten aanzien van vroedvrouwen, fyslotherapeuten, tandartsen, GAK-artsen, enz.

onder de verwijstak binnen de gezondheldszorg zijn de volgende categorleën te onderschelden:

- diagnostische verwifzingen;

- therapeut 1 che verwijzingen;

- consult;

- consultatle vragen;

- consultatle geven.

Verwijzen bulten de gezondheidszorg:

Hleronder versta $1 \mathrm{k}$ alle handelingen met de bedoeling het leggen van contacten voor individuele hulpverlening buiten de gezondheldszorg. Hilerbif is te denken an het Algemeen Maatschappel1jk Werk, Gez1ns- en Bejaardenhulp, Maaltijdverzorging, de Gemeentelijke Soclale Dienst en dergelijke. 
Veelal hebben patienten rechtstreeks toegang tot deze hulpverlenende instanties, zoals bijvoorbeeld het Algemeen Matschappelijk Werk. Op grond daarvan kunnen deze instanties bij de hulsarts om inlichtingen of advies over een bepaalde patiënt komen vragen. Ik heb dit als een vorm van consultatie geven door de hulsarts onder deze categorie onderscheiden. Ook kan het rogelijk zijn dat de huisarts consultatie vraagt om zich te orlënteren omtrent de hulpverleningsmogelijkheden ten aanzien van een bepaalde patiënt. De geoperationaliseerde categorieën zijn:

- verwijzen naar hulpverleners buiten de gezondheldszorg;

- inlichtingen vragen;

- Inlichtingen geven.

De begelelding:

Hieronder reken $1 k$ alle activiteiten, die gericht $z i j n$ op de curatieve en/of palliatieve zorg van chronische patiënten, gehandicapten, terminale patiënten en befaarden voor zover deze laatsten die zorg regelmatig nodig hebben. Ook de follow-up of nazorg van patiënten na of gedurende klintsche en/of speclalistische zorg valt hieronder. Bij chronische zieken, gehandicapten of terminale patienten zal de hulsarts vaak informatie en voorlichting moeten geven omtrent de aandoening, de prognose, pijnbestrijding, verpleging, revalidatie, patiëntenverenigingen en dergelijke.

De aan bejaarden verrichte zorgactiviteiten vormen pas dan een aparte, onder deze categorle te scoren groep, wanneer er sprake is van een zorg, die in eerste instantie geboden wordt, omdat de patiënt bejaard is, zoals bijwoorbeeld het geval is op een apart bejaardenspreekuur of zorg voor bejaarden met een chronlsch 11 jden.

Een bejaarde die bijvoorbeeld op het spreekuir komt met een incidentele urineweginfectle kan wat de hulsartsenactivitelten betreft ressorteren onder diagnostiek, theraple of verwijzen binnen de gezondheldszorg.

Voor die begeleiding zal de hulsarts in principe gebrulk maken van de handelings-categorleën zoals vermeld onder diagnostlek en therapie. Het is echter niet de bedoeling om die categorleën hler apart te scoren. Bljvoorbeeld het informeren naar veranderingen in de gezondheidstoestand van een chronisch zleke of het uitschrijven van een herhalingsrecept worden dus niet afzonderl1jk gecodeerd. Aldus worden 
de volgende categorleên onderscheiden:

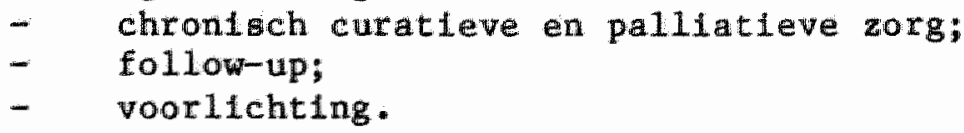

Preventie:

De activiteiten onder deze rubriek hebben als kenmerk het voorkomen van zlekten of verstoringen van de gezondheld en het zoveel mogelijk verhinderen van of anticiperen op verdere complicaties bij reeds aanwezige aandoeningen. Er wordt geen strikt onderscheid gemaakt in primaire of secundalre preventle. Preventle kan zowel diagnostische, therapeutische als bewakings- c.q. begeleidingsaspecten hebben. Deze activiteiten $21 \mathrm{jn}$ vooral gericht op de volgende categorleën van patiënten: zuigelingen en kleuters (zuigelingen- en kleutercontrole = perlodlek geneeskundig onderzoek), vrouwen $\mathbb{1 n}$ de fertlele leeftijd (pllcontrôles en andere vormen van geboorteregeling, cervixultstrijkjes, zwangerschap en postpartale controles), mensen, die op grond van bepaalde kenmerken of een predispositie voor een bepaalde zlekte of aandoening een verhoogd risico dragen. De activiteiten worden in de volgende categorieën gecodeerd:

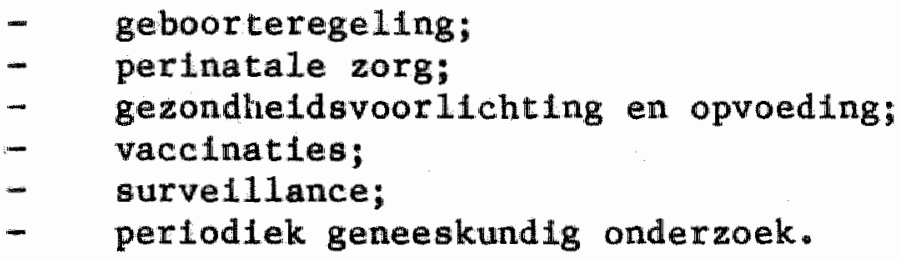

De ondersteunende werkzaamheden voor de praktijkvoering en taakvervulling (cond1ties):

Hieronder worden al die activitelten samengevat, die noodzakel1jk $z 1 \mathrm{jn}$ voor het kunnen functloneren als hulsarts. Hlerbij wordt gedacht aan praktijkvoering, het op pell houden van de eigen vakkennis, de kwaliteitsbewaking en de practische vormen van samenwerking. Als noodzakelijke voorwasdelifke activiteiten voor de praktijkvoering heb $1 \mathrm{k}$ onderschelden: prakt1 Jkorganisatle, registratie, administratie en correspondentie, relstijd (vervoer), telefoneren, apotheekwerkzaamheden ingeval van een apotheekhoudende praktijk, soclaal contact met patientten ( een bezoek aan de patient uit belangsteliing bijvoorbeeld in het zieken- 
huis, een "praatje" tijdens het spreekuur, e.d.), privetijd, dit is tijd voor persoonlljke bezigheden tijdens de werktijd overdag, nascholing en het geven van onderwijs of het optreden als huisarts-gastheer voor onderwijsstages. Het op pell houden van de elgen vakkennis en de kwaliteltsbewaking is gespecificeerd in alle vormen van nascholing variërende van het bestuderen van farmaceutische reclames via het lezen van vaktijdschrijften tot klinische demonstraties in het ziekenhuis. Onder praktische vormen van samenwerking vallen alle activiteften gerlcht op het onderhouden of tot stand brengen van samenwerking met andere hulpverleners in het eerste echelon, variërend van incidenteel overleg tot en met geformaliseerde werkbesprekingen. De genoende activitelten zijn te scoren in de volgende observatle-categorleën:

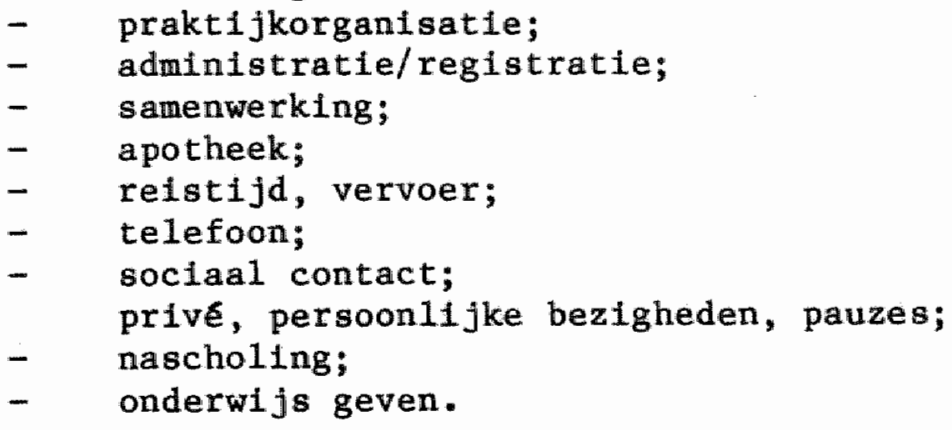

\section{Activiteiten als arts:}

Hiertoe behoren die activiteiten, die een hulsarts kan doen in zijn hoedanigheid als medicus. Dat betekent, dat ook andere categorieèn van artsen deze activiteiten kunnen en vaak ook zullen uitoefenen. In veel gevallen heeft gewoontevorming of beschikbaarheld er toe geleld, dat de hulsarts gevraagd wordt voor deze functies (bijvoorbeeld bestuurslid van een plaatselijke Rode Krulsvereniging).

De hier bedoelde activiteiten kunnen betrekking hebben op: keuringen voor rijbewijzen, levensverzekeringen en derge$11 j k e$, ziektecontrôles voor bedrijfsverenigingen, categorale preventie of groepsbegelelding, bijvoorbeeld zuigelingencontrôles op een consultatlebureau voor zulgelingen, spreekuur houden in Rutgershulzen, medisch adviseurschap bij stichtingen, organisaties of andere 1nstellingen, medische indicatiestellingen ten behoeve van de aanvraag van sociale voorzieningen, ontheffingen en dergelijke, be- 
stuurgfuncties In beroepsorganisaties en/of maatschappe11 jke en charitatieve instellingen.

Tenslotte is er nog een rest-categorie van andere activitelten zoals het geven van EHBO-lessen, parttime aanstelling als GGD-arts, bedriffsarts enzovoort.

De hiler bedoelde activitelten $z 1 j n$ te scoren in de volgende categorleèn:

- keuringen;

- groepsbegelelding;

- medisch adviseurschap;

- medische indicatiestelling;

- bestuursfunctie;

- andere arts-activitelten.

In het onderstaande schema worden de categorleën van het observatie-instrument nog eens vermeld:

DLagnost1ek:

- anamese;

- 11chame11jk onderzoek;

- elgen laboratorium onderzoek;

- ultbesteed laboratorlum onderzoek;

- uitbestede diagnostische bepalingen.

Therapie:

- medicatie;

- adviles;

- therapeutische handelling;

- gesprek;

- bevall1ng.

Verwifzen blnnen de gezondheldszorg:

- diagnostische verwijzing;

- therapeutische verwijzing;

- consult vragen;

- consultatle vragen;

- consultatie geven;

Verwijzen bulten de gezondheidszorg:

- verwijzing buiten;

- Inlichtingen vragen;

- Inllchtingen geven. 
Begeleiding :

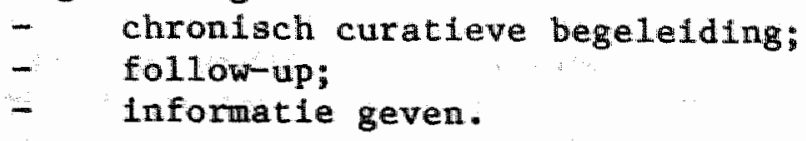

Preventle:

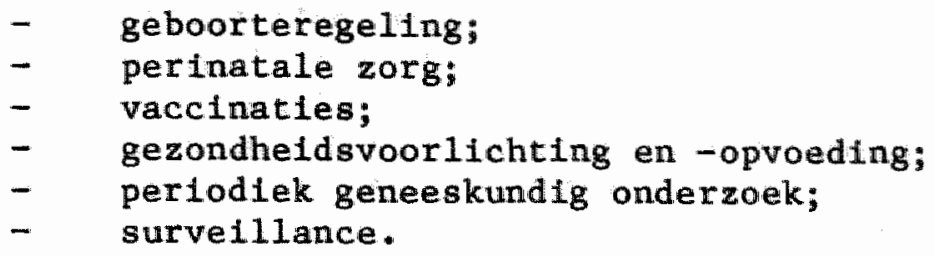

Condities:

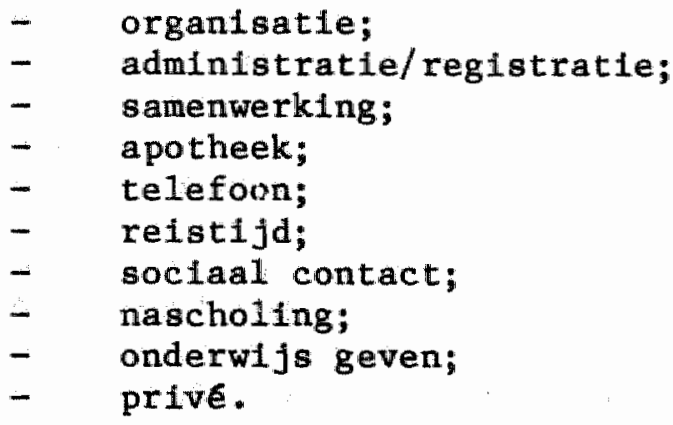

\section{Andere activiteiten:}

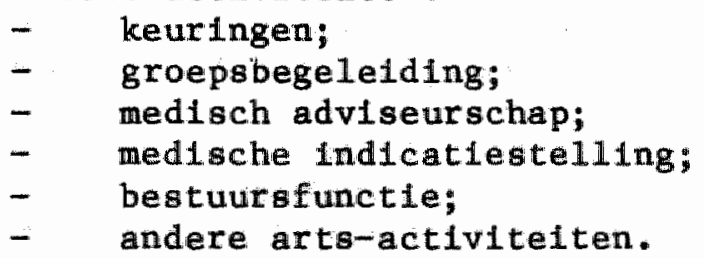

3.5. De geldigheld en de betrouwbarheid van de taakmeting. 3.5.1. De geldigheld.

Door middel van proefonderzoek is onderzocht of de te observeren handeling daadwerkelijk énduid $1 \mathrm{~g}$ onder de ontworpen observatie-categorieën te plaatsen waren. In dat proefonderzoek ging het er dus om de defintties van de observatie-categorieên op hun waarde te beproeven. Die defintties vormen immers de criteria aan de hand warvan de observato- 
ren tot een geldige reglstratie van de activiteiten zouden moeten komen.

Voor het merendeel van de te observeren activiteiten bleek dat de definities duidelijk waren. Er komen echter in de prakt1jk activiteiten voor, die op zich wel duidelijk zijn, maar desondanks nadere afspraken vergen wat betreft de codering. Het blijkt bijvoorbeeld, dat er huisartsen zijn, die op sommige dagen een kortdurend vrij spreekuur houden, waar als het ware aan de lopende band en in hoge frequentie patiënten voor welnig tijdvragende verrichtingen worden geholpen. Meestal gaat het daarbij om het verwijderen van hechtingen, controle op de genezling van wondjes, een injectle, een herhalingsrecept of een lavage van een gehoorgang. Omdat het voor ons niet zinvol was al dit soort verrichtingen afzonderlijk te registreren, is er afgesproken dat zo" $n$ "klussenspreekuurtje" gecodeerd zou worden met een combinatle van de codes: "medicatie" en "therapeutische handeling". Zo werd afgesproken, dat als mensen om een macht1ging vroegen voor orthopedisch schoelsel, een borstprothese en dergelljke, dit gecodeerd werd onder "therapeutische verwijzing". Zulgelingencontrôles van elgen patienten op het spreekuur moesten worden geregistreerd onder "periodiek geneeskund1g onderzoek". Zulgelingen- en kleutercontrôles verricht in een consultatlebureau, werden gecodeerd als "groepsbegeleiding" (groepspreventie). Tevens werd afgesproken, dat deze bijzondere activiteiten zouden worden genoteerd in het logboek, dat door leder van de observatoren tijdens de observaties $1 \mathrm{~s}$ bijgehouden. Met behulp van deze aantekeningen en de afgesproken codering konden in practisch alle gevallen dit soort handelingen door ons geIdentiflceerd worden. In de sporadische gevallen van onduldelijkheid of twijfel zijn de gegevens uit het bestand verwijderd.

In het proefonderzoek zijn we de meeste van deze activiteiten tegengekomen en werd de observator-instructle door ons op die punten aangevuld of verduidelijkt. In het definitieve onderzoek is tijdens de observatie-bijeenkomsten telkens aandacht besteed aan het coderen van bifzonderheden. Aldus werden in de eerste maand van het onderzoek nog enige bijstellingen aangebracht, daarna practisch niet meer. In geval van moellifkheden tijdens de observaties konden de observatoren ons telefonisch bereiken voor overleg. Dit is slechts sporadisch nodig gebleken en tijdens het elgenlijke 
veldwerk heeft zich geen enkele keer het felt voorgedaan, dat een activiteit niet onder de gebrulkte categorieen te scoren was. We mogen daarom met redelifke zekerheld aannemen, dat we over een valide observatie-instrument beschikten dat 11 zeggen dat de te meten begrippen adequaat in het categorieên systeem gepresenteerd waren of eenduidig konden worden ondergebracht.

3.5.2. De betrouwbaarheid.

Een cruciale factor bij de betrouwbaarheid is de interpretatiebreedte die de observator toepast. Immers het uitgangspunt voor de observatie 1 s dat de handelingen in een zinvolle context moeten worden geplaatst en niet zo zeer als afzonderlifke handelingen moeten worden gecodeerd. Het kader van die context is de taak, waronder die geobserveerde handeling geplaatst moet worden. De observator moet dus niet alleen de handeling, maar ook de intentie, die de huisarts er mee heeft, waarnemen. Met die combinatie van handeling en intentie is het gedrag onder de juiste observatie categorie te scoren Naarmate de observatie categorleën meer overeenkomen met de waarneembare activiteiten zal de scoring met grotere zekerheld plaatsvinden. Een onderzoek van de onderste extremiteiten bij een patiënt, die klaagt over een pifnlijke enke1, zal gemakkelijk als "11chamelijk onderzoek" gescoord worden. Zien we de huisarts daarna een recept uitschrijven voor een anti flogisticum, dan zal dat onder "medicatie" gescoord moeten worden en niet onder "apotheek" als de observatie zou platsvinden in een apotheekhoudende praktijk. De kans dat dat toch gebeurd zal kleiner zijn narmate de categorle "apotheek" scherper en vollediger gedefiniëerd is.

Om te zorgen voor een zo groot mogelljke betrouwbaarheld en unanimiteit in de interpretatie heeft er v66rdat het onderzoek van start ging een uitgebreide instructie en training plaatsgevonden van de observatoren. Bovendien zijn er voor dit doel testmetingen verricht met behulp van videobanden van echte spreekuren op de observator-b1jeenkomsten. In paragraaf 4.6.1. wordt hierop nog teruggekomen. De resultaten van de vier betrouwbaarheldsmetingen $z i \mathrm{fn}$ weergegeven in bijlage 1 . 
3.6. De representativitelt van de observaties.

De bedoeling was om met een observatie van vier a vijf halve dagen in een week per praktijk een registratie van het handelen te verkrijgen; 1 lefst in een verhouding waarin dat gewoonllfk voorkomt, zodat een betrouwbaar beeld van een doorsnee werkweek verkregen kon worden. De veronderstel ling dat zolets mogelijk is vindt onder andere steun in het gegeven ult het onderzoek van Aulbers en De Waard (1970) dat meer dan $90 \%$ van de activiteiten 1 een huisartspraktijk plaatsvindt tussen 08.00 en 18.00 uur en dat het aantal contacten met patienten redelijk gelijk over de werkdagen $1 \mathrm{~s}$ verdeeld.

Met de hulp van enlge LHV-distrlctsvertegenwoordigers kon voor het observatle-onderzoek een selecte steekproef van 93 hulsartsprakt1jken worden samengesteld. In paragraaf 4.7.1. staat vermeld op welke wijze dat precies is gedaan en welke selectlecriterla daarbij zijn toegepast.

In totaal zijn er in 93 huisartspraktijken 1452 uren geobserveerd. Dat betekent per prakt1jk een gemiddelde observatieduur van 15,6 ur In tabe1 3.5.1. Is weergegeven hoe die 1452 uur over de werkdagen zijn verdeeld.

Tabe1 3.5.1. Verdeling van de observatie uren over de werkdagen.

\begin{tabular}{ll} 
Dagen: & Uren: \\
\hline maandag & 261,7 uur \\
dinsdag & 421,4 uur \\
woensdag & 342,2 uur \\
donderdag & 291,9 uur \\
vrijdag & 134,8 uur \\
Totaal & 1452,0 uur \\
\hline
\end{tabular}

Uit deze tabel is af te lezen, dat er een redelljke sprelding over de verschillende dagen van de week aanwezig is. Het antal observatie uren op vrijdag is het geringst. Behalve de verdeling over de werkdagen is het van belang de verhouding tussen de observatlerubrleken per werkdag met elkaar te vergelijken. Onder observatierubrlek wordt ver- 
staan: afspraak- en vrije spreekuren. visites en overige activiteiten.

Die proportionele verdeling tussen spreekuren, visites en overige activiteiten is weergegeven in tabel 3.5 .2 .

Tabel 3.5.2. De proportionele verdeling van de observatierubrieken per werkdag (in procenten).

\begin{tabular}{lrrrrr}
\hline Rubriek & \multicolumn{1}{c}{ ma } & \multicolumn{1}{c}{ di } & \multicolumn{1}{c}{ wo } & \multicolumn{1}{c}{ do } & vrij \\
\hline visites & 28,6 & 24,4 & 25,7 & 20,8 & 25,4 \\
vrij spr.u. & 9,9 & 9,7 & 7,1 & 9,5 & 13,7 \\
afspr.spr.u. & 39,9 & 43,0 & 45,3 & 42,6 & 40,9 \\
overige act. & $\frac{21,6}{100,0}$ & $\frac{22,6}{100,0}$ & $\frac{21,9}{100,0}$ & $\frac{27,1}{100,0}$ & $\frac{20,0}{100,0}$ \\
\hline
\end{tabular}

Er blijkt een redelljke consistentle aanwezig in de proportionele verdeling over de werkdagen. Op geen van de werkdagen blijkt een observatierubriek over of ondervertegenwoordigd te zijn. De geringe verschillen zijn niet van systematische aard. Voorts is de verhouding tussen visiterijden spreekuur houden en de overıge, nlet patiënt-gebonden activiteiten op leder van de werkdagen nagenoeg constant. Dit is in overeensteming met de bevindingen van Aulbers en De waard (1970). Het is een aanwijzing, dat met een beperkte observatleduur verspreld over de werkdagen en over de dagdelen, een redelijk representatieve afspiegeling verkregen kan worden van een werkweek van hulsartsen.

\subsection{De toepassing van het meetinstrument,}

Met het ontwikkelde meetinstrument zijn de gegevens verzameld. die gedlend hebben voor het onderzoek van Boots (1983) en van mijzelf. In belde gevallen is gebrulk gemaakt van de zelfde analyse-eenheden. Dle analyse-eenheden $z 1 f n$ door Boots gebruikt ter invuliling van de zes onderscheiden functles. In mijn onderzoek is in die eenheden gezocht naar de feltelijke taakstructuur, die in het handelen van de hulsarts ligt opgesloten. 
3.8. Samenvatting.

In dit hoofdstuk 18 de ontwikkeling van het in dit onderzoek gebruikte meetinstrument beschreven. Het betreft een systeem van sbservatle categorieën, met behulp waarvan een directe niet participerende observatie van het handelen van hulsartsen is uitgevoerd. Het gaat daarbij niet zozeer on een registratie van het afzonderlijk handelen, als wel on de taak-intentle die de huisarts met die handelingen beoogt.

Een dergelijke doelstelling stelt speciale elsen aan het daarvoor benodigde observatle instrument. Aan de hand van 11teratuurgegevens $\mathrm{z} 1 \mathrm{jn}$ die elsen systematisch besproken en werd gelijktijdig een toelichting gegeven op welke wijze ik getracht heb aan die elsen te beantwoorden.

Speciale aandacht is besteed aan de training en de instructie van de observatoren en aan de controle op de betrouwbaarheld van de observaties. On de nauwkeurigheld van de observaties te bevorderen 18 een gedrags-observatie-registrator in gebruik genomen, waarmee de activiteiten van de hulsarts naar frequentle van voorkomen, volgorde en tijdsduur, gerubriceerd onder vrij- of afspraakspreekuur, visites en overige omstandigheden, zijn vastgelegd. Er is zoveel mogelifk getracht te voorkomen, dat de hulsartsen in hun handelen belnvloed zouden worden door de aanwezigheid van de observator. Vergelijking met gegevens uit eerder in Nederland ultgevoerd praktijk-analytisch onderzoek wijst er $o p$, dat wij met een beperkte observatieduur van ongeveer 20 uur in een werkweek per huisartspraktijk een redelijke representatieve afsplegeling van een doorsnee-werkweek van hulsartsen verkregen hebben.

De analyse-eenheden van het onderzoek betreffen de relatieve tijdsbestedingen van leder van de 43 observatie categorieèn per arts in de vorm van een percentage van de totale tijd, gedurende welke de huisarts is geobserveerd. Daar naast $z 1 j n$ het aantal recepten, eigen en ultbestede laborator Iumonderzoeken en verwijzingen per 100 arts-patiënt contacten als analyse-eenheden gebrulkt. 
Hoofdstuk 4. De opzet en de uitvoering van het onderzoek.

4.1. Inleiding.

In dit hoofdstuk komen opzet en uitvoering van het onderzoek aan de orde. Hlerbij is te bedenken, dat die opzet en uitvoering in felte het gezamenlijke werk is geweest van collega-onderzoeker Boots en van mijzelf. De ontwikkeling van het observatie-instrument wat betreft het systeem van observatie-categorieën is van mijn hand en is voor mijn verantwoordelijkheid. De taakperceptiemeting is inhoudelijk door ons belden samengesteld, verantwoord en verslagen. De methode van het onderzoek wordt besproken in 4.2 . In 4.3. wordt een overzlcht gegeven van de verzamelde gegevens. In 4.4. wordt besproken op welke wijze die gegevens zijn verzameld. De opzet en uitvoering van de observaties komen aan de orde in 4.5 .

Een bespreking van de geldigheid, betrouwbaarheld en de toepasbaarheid van de meetinstrumenten volgt in 4.6 .

In 4.7 . tenslotte wordt verslag gedaan van de controle op de representativiteit van de steekproeven.

4.2. De methode van het onderzoek.

Als men uit de activiteiten, die hulsartsen dagelifks verrichten, de taken wil afleiden dan is de meest ideale onderzoeksvorm een longltudinaal onderzoek, zeker als men de Invloed van enige factoren op de taakultoefening wil onderzoeken. Het onderzoek van Jansen-Emmer (1958) is een longltudinale studie. Aanvankelijk wilde zij de vier geselecteerde praktijken leder een jaar lang observeren. Dit bleek dermate bewerkelijk en zodanige practische bezwaren met zlch mee te brengen dat slechts een praktijk een jaar geobserveerd 1s, twee praktijken drie maanden en de laatste een half jaar. Ook wilj konden om technische en practische redenen zo'n longitudinaal onderzoek niet uitvoeren en hebben ons moeten beperken tot een transversaal onderzoek.

\subsection{De verzamelde gegevens.}

De voor de oplossing van de eerste vraagstelling benodigde gegevens, de afhankelijke variabelen in het onderzoek, zijn de per arts gemeten relatieve tijdsbestedingen an leder 
van de 43 observatlecategorleën.

De onafhankelijke vartabelen, behorende bij de tweede vraagstelling, zijn de door mij gekozen werksituatie-, werkw1jze- en persoonskenmerken van de huisarts. Mede op grond van de resultaten van het 11 teraturonderzoek zijn de volgende onafhankel1 jke variabelen gekozen:

\section{Werksituatie:}

\section{- praktijkgrootte}

- prakt1jkvorm

- leeft1jdsopbouw van de bevolking in de gemeente van vestiging

- ziekenfonds-particulieren ratio

- gemiddeld aantal patiënten per observatie-uur per huisarts

Werkw1jze:

- aantal laboratorlum-onderzoeken per 100 arts-patiënt contacten

- aantal verwilyzingen per 100 arts-patiënt contacten

- consult-visite ratio

- ultgebreidheid van het instrumentarium

De uitgebreidheid van het in de praktijk aanwezige instrumentarium fungeert als een proxi voor de mate waarin gebruik gemaakt wordt van instrumenten. Om methodologische redenen 18 ervan afgezien tifdens de observaties het gebruik van instrumenten te laten registreren. We veronderstellen echter, dat als een arts een uitgebreld instrumentarlum heeft aangeschaft hij dat ook gebruikt. U1teraard zit hier een onnauwkeurigheld in, warvan we de grootte niet kunnen aangeven.

Persoon van de arts:

- het aantal jaren praktijkervaring als hulsarts

- taakopvattıng

- bereldheld tot samenwerking met andere disicplines

- opvatting omtrent het ter beschikking hebben van voldoende tijd en voorzleningen ten behoeve van de taakultoefening 
4.4. De wijze van gegevensverzameling.

Voor de meting van de breedte in taakopvatting van huisartsen is gezocht naar die onderdelen in de takkonschrifwing, waarover binnen de beroepsgroep meningswerschillen bestaan of ze al dan niet tot het takenpakket moeten behoren. Over leder onderwerp van discussie is een positief en negatief geformuleerde vraag in een vragenlijst opgenomen. Deze werkwijze heeft geleld tot een meetinstrument van de taakopvatting met een zo groot mogelijk discriminerend vermogen. Over de discussiepunten in de takstelling en de afbakening naar andere disciplines heeft elnd 1978 overleg plaats gevonden met de Commissie Takenpakket van de LHV. Per functle werden onderwerpen verzameld, dle ook naar de mening van deze commissie te beschouwen zijn als indicatief voor de verschillende meningen omtrent de breedte van de bijbehorende taak.

Naast de breedte in taakopvatting per functle zijn vragen opgesteld met behulp waarvan het gewenste niveau van het medisch-somatisch handelen ten aanzlen van diagnostiek en theraple kon worden uitgedrukt. Tenslotte is per functie gevraagd of men daar de nodige hoeveelheid tijd voor beschikbaar heeft en of er voldoende gezondheidszorgvoorzieningen ter ondersteuning van de taakuitoefening aanwezig zijn. Aan de vragenlijst zijn bovendien vragen toegevoegd betreffende de leeftijd van de huisarts en de datum van afstuderen. Dok zijn vragen opgenomen ontrent een aantal objectieve praktijkkenmerken en de praktijkpopulatie.

Omdat de vragenlijst niet alleen gebrulkt is bij de huisartsen, die in het observatie-onderzoek betrokken waren, maar tevens bij een als representatief geldende steekproef van Nederlandse hulsartsen (zie 4.9.) zijn aan de vragenlijst nog toegevoegd:

- attitude-vragen betreffende de arts-patiënt verhouding en de arbeidssatisfactie;

voor de LHV relevante vragen betreffende de warneming, de nascholing, de 1 tercolleglale toetsing, de medicatiebewaking en het prescriptie- en vestigingsbeleid.

Het demografische kenmerk dat gehanteerd wordt (de leef- 
t1jdsopbouw van de bevolking in de gemeente van vestiging), vervult in dit onderzoek de rol van indicator voor de leeft1jdsopbouw van het patientenbestand. Het betreft de leeft1javerdeling volgens de CBS-classiflcatie per 1 januar1 1979, gespeciflceerd naar geslacht per gemeente van vest1ging. Dit gegeven is op gemeenteniveau verzameld omdat slechts zeer weinig praktijken over een up-to-date leeft1jds- en geslachtsreglster beschikken. Men mag aannemen, dat in gemeenten met 3000 a 4000 inwoners de daar gevestigde hulsarts een prakt1jkpopulatie heeft, die qua opbouw en samenstelling niet sterk zal afwijken van de gehele gemeente. In grotere gemeenten 18 dit niet zonder meer aan te nemen. Over de wijze warop de praktijkopbouw dan tot stand kont - In relatle tot b1jvoorbeeld de persoonskenmerken van de hulsarts - is te weinig bekend om hierop gebaseerd, verantwoorde correcties in de demografische kenmerken op gemeentelijk niveau te baseren. We nemen voorlopig aan, dat de verdeling van de verschillende categorieën van patiënten over de aanwezige hulsartsen min of meer a-select verloopt.

\subsection{De observatiemethode.}

De argumenten on te kiezen voor een observatie-onderzoek zijn zowel van practische als methodische aard. Huisartsen zelf hun werkzamheden laten registreren, zou een extra tijdbelasting voor hen betekenen. Of men nu na afloop van ledere dag of week of na leder consult vraagt te noteren wat er heeft plaats gevonden en hoeveel tifd een en ander gekost heeft, in alle gevallen zou dat de betreffende huisarts extra tijd kosten en zijn motlvatie om aan het onderzoek deel te nemen, zou hierdoor worden belnvloed.

Een tweede bezwaar van doorslaggevende betekenis tegen het door huisartsen laten registreren van de elgen activiteiten, $1 \mathrm{~s}$ de geringe betrouwbarheld. Tussen de resultaten verkregen door observatie en die, door hulsartsen zelf geregistreerd, kunnen zeer grote verschillen bestaan, met name door de neiging de tijdsduur van de elgen activiteiten te overschatten (Nelson et a1., 1975).

Voor observatie zijn observatoren nodig, die in staat zijn on de door de onderzoeker opgestelde observatie-categorileẻn te verbinden met de wargenomen handelingen. De interpretatie, die de observator hierbif moet verrichten, bleek bij 
ons systeem van observatle-categorieën nogal specifiek, waardoor besloten is on (huis-)artsen als observateren te werven. Dat had bovendien nog een ander voordeel: er zijn minder bezwaren te verwachten tegen de anwezlgheld van artsen bij het arts-patiënt contact dan van leken, zowel van de kant van de patiënt als van de arts.

\subsection{De meetinstrumenten.}

Voor de uitvoering van het onderzoek zijn twee meetinstrumenten ontwikkeld:

a. Een systeem van observatie-categorleën.

b. Een vragenlifst voor het meten van de takopvatting. De ontwikkeling van het systeem van observatie-categorieern is reeds besproken in hoofdstuk 3. De opzet van de observaties, de voorbereldingen ervoor en de betrouwbaarheidsmeting zullen hier besproken worden. Daarna worden de ontwikkeling, de toepassing, de geldigheid en de betrouwbaarheld van de enquete behandeld.

4.6.1. De observaties.

In 1977 werden de voordien geteste observatie-categorieën toegepast in een proefonderzoek bij zeven huisartsen in Zuld-Limburg en tien hulsartsen in de regio Arnhem. Deze meting was opgezet om de toepassing van observatie in de huisartspraktijk als methode van gegevensverzameling te onderzoeken. Naast de practisch uitvoerbaarheid werden de problemen van de geldigheid bestudeerd (zie 3.5.).

De Instructle van de observatoren in het gebruik van de observatle-categorieën bleek goed uitvoerbaar. Het interpreteren van het wargenomen handelen bleek voor (huls-)arts-observatoren weinig moellijkheden op te leveren.

Bij de uitvoering van de observaties in het elgenlijke onderzoek deden zich drie problemen voor:

- het vinden van arts-observatoren,

- het verkrijgen van de medewerking van hulsartsen, en

- de registratie en de verwerking van de gegevens.

De benodigde observatoren $z \mathbb{1 j n}$ via contacten met de Landelijke Vereniging van Arts-assistenten verkregen en op contractbasis voor de tijd van drie maanden aan de Rifksuniversitelt Limburg verbonden. 
De hulsartsen die hun praktijk en hun werk wllden laten observeren, zifn geworven dank zij de bemiddeling van contactpersonen in de Platselijke Hulsartsen Verenigingen.

Het reglstreren van de gegevens gebeurde in de pllotstudie met behulp wan voorgedrukte formulleren, waarop de observator het begln- en eindpunt van een categorle moest aangeven op een tijdbasis van minuten. Bovendien werden in deze pilotstudie verschillende formulieren voor vrij spreekuur, afspraakspreekuur, visite, overige en verwijzingen gebrulkt. Zowel de keuze tussen het gebruik van de verschillende formulteren als het volgen van de $t 1 \mathrm{jd}$, leverde de observator nogal veel moellijkheden op. Bovendien was de computerverwerking - en met name de codering - nogal omslachtig, waardoor allerle1 verwerkingsfouten ontstonden.

In het ulteindelljke onderzoek is daarom een andere methode gehanteerd. Speclaal ten behoeve van dit onderzoek is een zogenaamde gedragsobservatle-registrator (G.O.R.) ontwikkeld, in samenwerking met de technisch-instrumentele werkplaats van de Rijksuniversiteit Limburg (Boots, 1980). Met behulp van dit apparat werd het mogel1jk dat de observator alleen het begin van een categorie aangaf, waarbij automatisch de scoring op een tijdas met intervallen van 10 seconden werd vastgelegd, onder gelijktijdige registratie van een vooraf ingestelde rubriek: visite, afspraakspreekuur, vrij spreekuur en overige. Het opslaan van deze scoringen vond plaats in een geheugen-cassette. De inhoud hiervan werd vervolgens - met behulp van een hlervoor ontworpen Interface - direct op MINC-apparatuur overgenomen. Aldus werden de door de observator gedane waarnemingen volgens een vooraf opgestelde code-identificatie-systeem met de bifbehorende rubricering en tijdsduur vastgelegd op magneetschilven. Deze ruwe gegevens werden door ons gecontrôleerd op fouten, dle ontstaan waren door haperende apparatuur, onoplettendheid van observatoren, e.d. De contrôle berustte nlet alleen op het opsporen van eventuele interne inconsistenties in de gegevens, mar ook op het corresponderen van de observatiegegeven met de, gedurende de observatie schriftelijk vastgelegde, Informatie in het zogenaamde logboek, dat 1 edere observator b1jhield. Hierin werden al die gebeurtenissen vermeld die van een afwijkende vorm waren, en nlet in de observatle-categorleën konden worden weergegeven. Hieronder vielen bijvoorbeeld het langdurig 
verrichten van ernzelfde handeling, zoals het doen van consultatlebureauwerk; evenals het gelijktljdig behandelen van verschillende patiënten. Bovendien werd het specialisme warnaar verwezen werd in het logboek vastgelegd. Wanneer interne inconsistenties of niet-corresponderende gegevens tussen observatle en logboek werden geconstateerd, probeerden we deze met behulp van de observator te corrigeren. Bij twijfel werd de betreffende registratie ult het bestand verwijderd. Alle registraties warbij mogelijke mechanische fouten konden zijn ingeslopen werden zonder meer verwijderd. De apparatuur, en met name de geheugencassettes, werden frequent gecontroleerd, gemiddeld $1 \times$ per week. De uitval ten gevolge van mechanische defecten bedroeg minder dan $1 \%$ van het totale bestand. Omdat de observaties plaats vonden gedurende maximaal 20 uur in een praktijk in én week, en wel tussen 08.00-18.00 uur, werden voor de resterende t1jd tussen de observaties speciale registratiekaarten gehanteerd, die door de hulsarts zelf werden ingevuld. Hierop werd gevraagd naar een globale aandulding van de activitelten gedurende avond- en nachtdienst en, indien van toepassing, weekeind- en waarnemingsdiensten.

In totaal werden dus ten behoeve van de taakmeting de volgende gegevens per hulsarts verzameld:

1. 20 uur geobserveerde activiteiten in v66rgecodeerde categorieën en rubrileken, op een tijdas met een interval van 10 seconden;

2. een logboek door de observator Ingevuld, waarin gegevens over alle bljzondere omstandigheden die zlch tijdens de observatle voordeden, en ook in leder geval. het speclalisme waarnaar verwezen werd, per afzonder$11 \mathrm{jk}$ gereg1streerde verwijzing;

3. door de geobserveerde hulsarts zelf in te vullen gegevens over de avond- en nachtwaarneming en/ of weekelnddiensten.

Wat betreft de geldigheid van de rangschikking van de observatie-categorleën onder de taakrubrleken wordt hier volstaan met de vermelding dat ledere indeling in omschreven categorleën berust op de "face value" van deze aandulding, naar het oordeel van ervaren hulsartsen. In hoofdstuk 6 
wordt hiler nader op ingegaan.

De betroutbaarheld betreft de hierboven onder 1 genoemde gegevens. Ter verkrijging van een zo groot mogelljke betrouwbaarheld werden de volgende matregelen getroffen. Aan het begin van de observatleperiode werd per categorle een 1mstructle verstrekt aan alle observatoren. Deze instructie werd mondeling in een gezamenlijke bijeenkomst met mill als hulsarts-onderzoeker doorgenomen op onduldelijkheden of de mogel1jkheid van meerdere interpretaties. Bovendien werd gedurende deze eerste bijeenkonst geoefend met observeren en de G.O.R.-apparatuur aan de hand van de hiervoor speclaal geselecteerde video-opnames van hulsartsenspreekuren.

Deze videobanden betroffen "normale" consulten, dus geen speciaal voor instructies of demonstraties vervaardigd materiaal. Alle activitelten die op deze banden waarneembaar waren, werden v66r de instructlebijeenkomst door de hulsarts-onderzoeker geobserveerd en geregistreerd in mijn categorleén, op grond van de geldende instructies. Aanslultend an de observatie van de opname door de observatoren, gezamenl1jk en gelijktijd1g zonder onderling overleg, werden de door de observatoren gemaakte scores vergeleken met de resultaten van mijn observatie. Indien noodzakelijk, werden de instructies op grond van deze vergelijking bijgesteld.

Gedurende de observatieperiode werden nog vier b1jeenkomsten met de observatoren gehouden. Bil deze gelegenheden werden nieuwe videobanden aangeboden en gehanteerd, zoals hierboven omschreven. Bovendien werden per observator de Interpretatleproblemen besproken, zo nodig telkens resulterend in cenduidige (nlewwe) afspraken. Geconstateerde afwljkingen, werden door ons gecorrigeerd en in het reeds verzamelde materlaal verwerkt. Deze bifeenkomsten vonden plaats na de eerste, tweede, derde en zesde week van de observatiepertode. Aan de observatiegegevens van de op videoband aangeboden hulsartswerkzaamheden zijn de scores van mijn scores toegevoegd. Per v6rrkomende observatlecategorle zijn de verschillen in scores tussen de observatoren - op v6örkomen ên tijdsduur - ${ }^{\circ}$ p significante afwijkingen getoetst met behulp van de $x^{2}$ toets. Uit deze toetsing blifkt dat de observatoren onderling en in vergelijkling met de "te verwāchten score" vrijwel geen significant verschillende waarnemingen deden. (bijlage 2). 
4.6.2. Taakperceptie-meting.

De taakperceptie werd gesplitst naar de zes taken (aie hoofdstuk 3), waarbij per taak uitspraken werden voorgelegd, die voornamelijk het zogenaamde facultatleve gebled betroffen uit het "Takenpakket", (LHV, 1977). Per taak betekende dit de hlernaast genoemde onderwerpen, waarbij te1kens twee (positieve en negatieve) ultspraken werden geformuleerd betreffende hetgeen de hulsarts tot zijn taak behoort te rekenen.

Diagnostlek:

- sociale problemen in de diagnose betrekken of zich beperken tot somatiek;

- als huisarts zoveel mogelijk zelf diagnosticeren en dan pas gerlicht verwijzen;

Therapie:

- gesprekstechniek als eigen vaardigheid uttoefenen;

- bevallingen zelf begeleiden;

- zo welnig mogelijk verwijzen naar hogere echelons;

Begeleiding:

- begelelding door de hulsarts ook van high risk-groepen, psychiatrische patiënten, stervenden en revalidatiepatiënten;

Preventie:

- niet alleen individueel, ook groepspreventie als hulsartsentaak;

- niet alleen beperken tot somatische aandoeningen, ook uftbreiden tot matschappelijke probleemsituaties betreffende soclale klachten;

Verwijzing binnen de gezondheldszorg:

- relatie met specialisten met betrekking tot te delegeren verantwoordelijkheden;

- kostenaspecten mee laten wegen in het al of niet verwijzen;

Verwijzing bulten de gezondheldszorg:

- verantwoordelijkheid van de huisarts voor hulpverle- 
ning bij soclale problemen;

- verwijzende functie van de huisarts bij matschappe11.jke problemen.

Aan deze vragen werden telkens per taak twee vragen toegevoegd met betrekking tot de ervaren tijdsdruk en de ondervonden steun bif de betreffende taak-ultoefening door aanwezige gezondheldszorgvoorzleningen. Tenslotte werden acht vragen gesteld betreffende eén van de centrale elementen in "cond1ties", namel1jk het samenwerken met andere eerste11 jns werkers. Zoals reeds aangegeven in hoofdstuk 3 werd de meting van aanwezigheid van gezondheldszorgstructuren niet alleen op objectleve informatie gebaseerd. In de vragenlijat is opgenomen een aantal voorzieningen, waarvan aan de hulsartsen gevraagd is om aan te geven hoe frequent men deze gebruikt en hoeveel nut men hieraan toekent bij het functioneren als hulsarts.

Het niveau, warop diagnostiek en theraple zouden moeten worden ultgevoerd, 18 gemeten aan de hand van een aantal ultspraken, die de ultgebreidheid van het somatisch-technlsch handelen van de hulsarts probeert te traceren.

De vragenlljst werd in $z 1 j n$ conceptvorm doorgesproken met de leden van de LHV-Commissie Takenpakket. Vervolgens werd de eerste versie voorgelegd an twee hulsartsen, die namens het Medisch Regional Centrum Zuld-Limburg ons project begeleldden en aan een aantal artsen en niet-artsen uit de elgen unfversitalre kring. De ultspraken werden, op grond van uit een proefmeting verkregen resultaten, vervolgens genelecteerd op onderscheldend vermogen, begrijpelijkheid en eenduidigheid. Uiteraard werd op basis van de gegeven commentaren ook de lengte, opbouw en lay-out van de $11 j \mathrm{st}$ bijgesteld.

De vragenllyst werd aan de geobserveerde hulsarts door de observator overhandigd. De hulsarts werd geacht zelfstandig de $11 j s t$ in te vullen, waarna de observator voor retournering zorg droeg. Aan de hulsartsen in de landelljke, representatieve steekproef werd de vragenlijst, in dezelfde perlode als de observaties werden ultgevoerd, per post toegezonden.

De geldigheld van de vragenlijst is gebaseerd op de "face 
value" en "expert opinion". De geconstructeerde geldigheid betreft de vooraf gecreëerde samenhang van de uitspraken en de wijze van selectie.

De betrouwbaarheld van de meetresultaten hebben we bovendien nog op de volgende wijze trachten te verhogen. Naast de steekproef die we getrokken hebben ten behoeve van het observatle-onderzoek volgens de eerder beschreven probleemstelling, hebben we bovendien een grotere steekproef samengesteld uft het huisartsenbestand in Nederland. Deze werd getrokken op basis van representativiteit op de kenmerken: solist/niet-sollst; urbanisatiegraad van praktijkgemeente en praktijkgrootte. Aan deze steekproef werd tevens dezelfde vragenlifst voorgelegd met een begeleldende brlef van de LHV-voorzitter. Het gebruik dat we van de resultaten uit de "post-enquete" maken is tweeërlel: allereerst een contrôle op de representativiteit van de elgen steekproef, anderzijds een mogelijkheid om de meting van taakopvattingen op betrouwbaarheld te onderzoeken.

\section{Samenvattend :}

Ten behoeve van het onderzoek zijn twee nleuwe instrumenten ontwikkeld, getest en toegepast, name11jk de observatie-categorleën en de taakperceptievragenlijst. In een proefonderzoek werden betrouwbaarheid en geldigheid van het observatie-instrument onderzocht. In het uiteindelijke onderzoek werden naast de observatlegegevens, aanvullende gegevens genoteerd warmee betrouwbarheidcontrôle mogelljk was. Tijdens de observatieperiode werden tevens een vijftal test-observaties ultgevoerd met behulp van video-opnamen. Het verschil tussen observatoren en onderzoekers bleek bil de toepassing van de observatlecategorleën over vrijwel alle categorleën nlet significant.

De meting van de taakopvatting door middel van een vragenlijst werd nlet alleen in de onderzoeksgroep uitgevoerd, maar tevens in een representatieve steekproef van Nederlandse hulsartsen. Blj de constructle van de ulteindelijke schalen volgens onderdelen van de taakopvatting werden de uitkomsten ult de representatleve steekproef gebruikt. De geldigheid van beide instrumenten berust op "face value" 
van terzake kundlge hulsartsen en onderzoekers.

\subsection{Steekproeven.}

Zoals in het voorgaande reeds aangegeven is, zljn ten behoeve van dit onderzoek twee steekproeven getrokken een groep hulsartsen warbij alle onderdelen van het onderzoek werden uitgevoerd (verder te noemen kleine steekproef), en een groep hulsartsen waraan alleen de perceptievragenlijst werd voorgelegd (verder te noemen: grote steekproef).

\subsection{1. "Kletne" ateekproef.}

De gekozen techniek van gegevensverzameling met betrekking tot taak ultoefening, namelijk de directe observatie stelt practlsche beperkingen aan de omvang van de steekproef. Op grond van de ons ter beschikking staande middelen en om een nog hanteerbare organisatie te behouden in relatie tot het beschlkbare projectmanagement, werd gekozen voor een kleine steekproef van 93 huisartsen.

Bij de samenstelling van deze steekproef golden de volgende overweg1ngen:

1. In de te onderzoeken groep hulsartsen moeten zo goed mogelijk alle voor de probleemstelling relevante kenmerken. zowel van huisartsen. praktijken, als van de structurele ongeving aanwezig zijn.

2. De bereidheid tot medewerking van huisartsen vergt een zorgvuldige voorlichtings- en voorbereldingsprocedure, waardoor de kans op selectieve uitval, niet denkbee1dig bij een "gevoelig" onderwerp en uitgevoerd met behulp van een "bedrelgende" methode, zo gering mogelijk wordt gemaakt.

Uit de eerste overwegling volgde de samenstelling van een "purposive quota sample" (Kerlinger, 1964 p. 129), gericht op de volgende kenmerken:

landelijke diversiteit van regionale kenmerken met betrekking tot urbanisatie en voorzleningenniveau;

spreiding in praktifkkenmerken, met name samenwerkIngsvorm wel of niet apotheekhoudend omvang en verhouding van aantal zlekenfondspatienten ten opzichte van particullere patienten;

spreiding in persoonskenmerken, vooral wat betreft 
leeftijd en/ of ervaring als hulsarts.

Voor het bereiken van de reglonale spreiding werd Nederland verdeeld in 24 mini-provincles, volgens een ontwerp van het Minlsterle van Blnnenlandse Zaken, d.d. februari 1977. Voor deze indeling werd gekozen, omdat indertijd het voornemen bestond de regionalisatie, ook ten behoeve van de gezondheidszorg, te laten verlopen in deze geografische indeling.

In samenwerking met het MEMIC (Medisch en Maatachappelijk Informatiecentrum) van de Rljksuniversiteit Limburg werden deze 24 mint-provincies vergeleken op: urbanisatiegraad, huisartsendichtheid en aanwezigheid van gezondheldszorgvoorzieningen. Uit de hierop gebaseerde typologieën werden de volgende acht mini-provincles geselecteerd:

1. Overijssel en Groningen: "platteland met stadskern".

2. Zuid-Limburg en Kempenland: "sterk geurbaniseerd platteland".

3. Goo1, Eemland, Hameland: "forensisch gebled".

4. Haagland en Rijnmond: "grote steden".

Bij het realiseren van diversiteit in praktijk- en persoonskenmerken speelde tevens de hlerbovengenoemde tweede overweging een rol. De selectie van de uitelndelijk in de steekproef op te nemen praktijken verliep via de LHV-districtvertegenwoordigers in de genoemde gebieden. Aan deze disctrictvertegenwoordigers werden in een persoonlifk contact met de onderzoekers de opzet en doelstelling van het onderzoek uitgelegd. Aan hen werd gevraagd om in "hun" district 12 artsen te zoeken, met de voor ons onderzaek relevante persoonskenmerken en praktijksituatles. Met de aldus samengestelde groepen werd per regio een voorlichtend gesprek gehouden door de onderzoekers. Uitval door weigering van medewerking heeft zich nlet voorgedaan.

\subsection{2. "Grote" steekproef.}

Een gerandomiseerde steekproef van 900 huisartsen werd getrokken uit het totaal van in Nederland zelfstandig gevestigde en full-time werkzame huisartsen per 1 Januar 11979. Hiervoor werd gebruik gemakt van het adressenbestand van het Nederlands Huisartsen Instituut. De vragenlifst werd, vergezeld van een aanbevelingsbrlef van de LHV, toegezonden. De respons van $70 \%$ mag voor een schriftelijke enquête 
hoog genoemd worden. Na contrôle bleek een aantal van 614 vragenl1jsten geschlkt voor verdere verwerking.

\subsubsection{Representativiteit.}

Vergelijkling van belde steekproeven op voor dit onderzoek relevante vartabelen, met de populatiegegevens levert het volgende resultaat op.

Tabel 1: Vergelijking naar urbanisatiegraad van beide steekproeven met de populatie van zelfstandig gevestlgde hulsartsen in Nederland die full-time werkzaam zijn, per 1 januari $1979 \mathbb{1 n}$ percentages van het totaul.

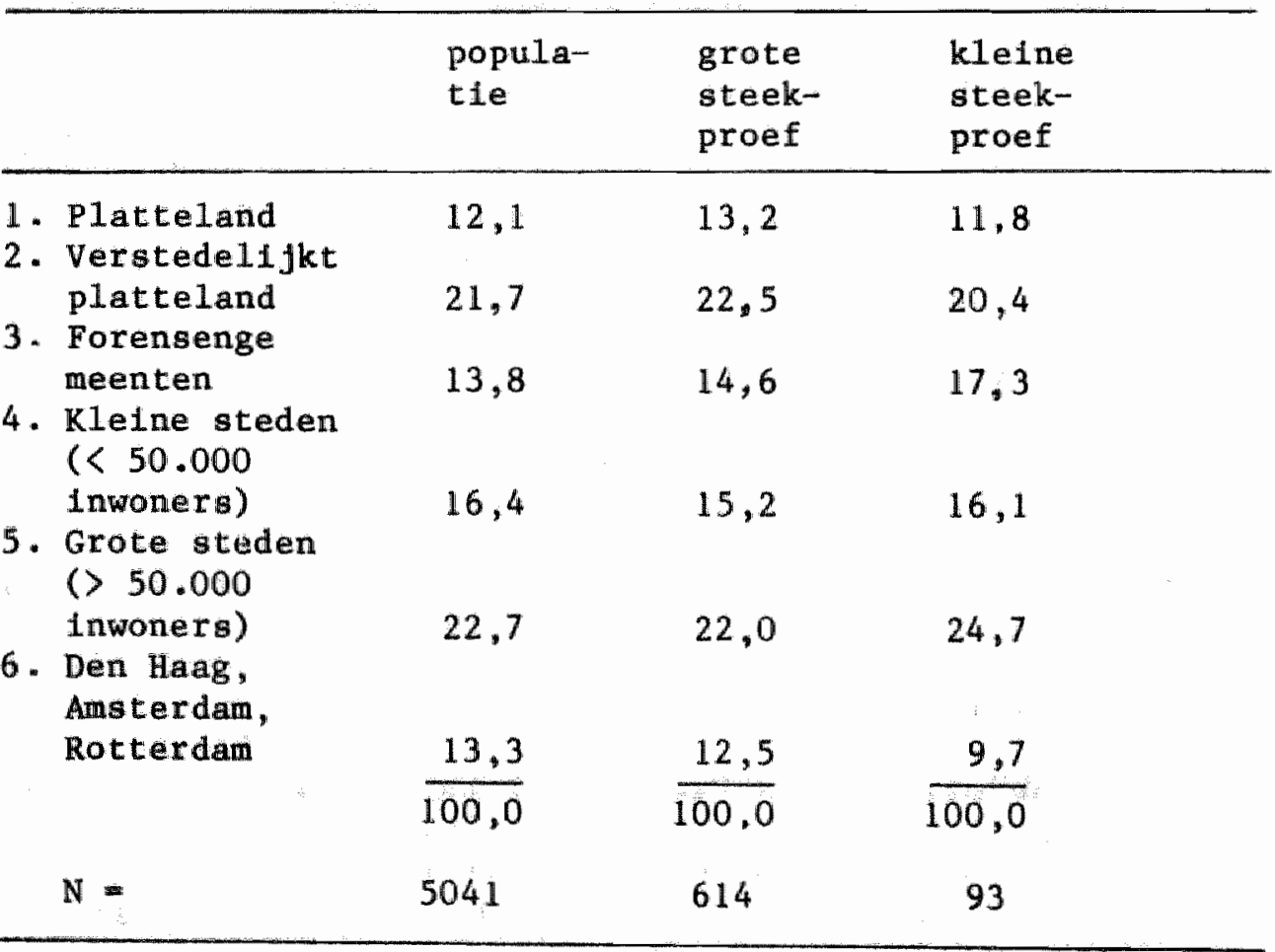

Het verschil tussen de populatie en de beide steekproeven is niet significant. $\left(x^{2}=0,2 ; x^{2}=0,3 ; \alpha=0,5\right)$. 
Tabel 2: Vergelijking naar praktijkvorm van belde steekproeven met de populatie van zelfstandig gevestigde huisartsen in Nederland die full time werkzaam zijn, per 1 januari 1979 in percentages van het totaal.

\begin{tabular}{llll}
\hline & $\begin{array}{l}\text { popula- } \\
\text { tie }\end{array}$ & $\begin{array}{l}\text { grote } \\
\text { steek- } \\
\text { proef }\end{array}$ & $\begin{array}{l}\text { kleine } \\
\text { steek- } \\
\text { proef }\end{array}$ \\
\hline $\begin{array}{l}\text { 1. Solist } \\
\begin{array}{l}\text { 2. Niet-solist } \\
\text { 3. Apotheek- } \\
\text { houdend }\end{array}\end{array}$ & 64,3 & 67,5 & 65,1 \\
$\begin{array}{l}\text { 4. Niet- } \\
\text { apotheek- } \\
\text { houdend }\end{array}$ & 26,5 & 32,5 & 34,9 \\
& $\frac{73,5}{100,0}$ & $\frac{71,2}{100,0}$ & $\frac{67,7}{100,0}$ \\
\hline $\begin{array}{l}\chi^{2}=\text { resp. } \\
\alpha=0,5.74 ;\end{array}$ & 0,$02 ; 1,67 ; 1,61 ;$ & 32,3 \\
\hline
\end{tabular}

U1t de vergelijking van belde steekproeven met de populatie blijkt voor de betreffende kenmerken geen significant verschil te bestaan. Ook de combinatie van deze kenmerken levert geen significante afwijkingen van de populatiegegevens op.

Samenvattend.

Het observatie onderzoek ten behoeve van de taak-analyse 1 is uitgevoerd in een steekproef van 93 huisartsen. Deze steekproef werd samengesteld aan de hand van een aantal kenmerken van de artsen, praktijken en hun omgeving, dat relevant is voor de probleemstelling. De medewerking van de geselecteerde hulsartsen werd verkregen door bemiddeling van reglonale contactpersonen.

Een aanvullende steekproef, waarb1j alleen de vragen11jst werd voorgelegd is getrokken uit het totale huisartsenbestand, per 1 januari 1979 , op basis van representativiteit. Beide steekproeven zijn op significante verschillen met de populatie onderzocht; deze bleken niet aanwezig te zijn. 
Hoofdstuk 5. De beschrijving van de variabelen:

meetreaultaten.

5.1. Inleiding.

In dit hoofdstuk worden de meetresultaten van het observatie onderzoek en van de vragenlijst beschreven. In 5.2 is beschreven hoe de absolute tijdeenheden per observatie categorie zijn getransformeerd tot analyse eenheden.

In 5.3. komt eerst aan de orde hoe de gegevens voor de verklarende variabelen zijn verzameld en daarna worden de gemiddelde waarden van de gemeten onafhankelijke variabelen in een samenvattend overzicht weergegeven.

5.2. De tijdsvarlabelen.

De eerste vraag, die wij in dit onderzoek willen bestuderen heeft betrekking op de taakstructuur dle schull gaat achter de activitelten, die hulsartsen in hun dagelijkse werk verrichten. Met het door ons gebrulkte technische hulpmiddel bij de observaties (de G.0.R.) zijn de waargenomen activiteiten van huisartsen geregistreerd naar frequentie van voorkomen, volgorde en tijdsduur.

Utt de bestudeerde ilteratuur is tijdgebrek als een dominante factor bij de taakuitoefening van de hulsarts naar voren gekomen. Het lag daarom voor de hand om de analyseeenheden in een tijd dimensie uit te drukken. Per huisarts zijn de wargenomen absolute tijdsbestedingen aan leder van de 43 observatie categorieèn omgezet in een relatieve tijdscore, namelijk in een percentage van de per hulsarts totaal geobserveerde tijd. Daarmee worden de observaties onderling vergelifkbaar. Reeds is opgemerkt dat een transversaal onderzoek tot grote voorzlichtigheid noopt ten aanzien van de conclusies. Toen bleek dat van de 93 geobserveerde praktijken er twee minder dan 10 uur geobserveerd waren, heb $1 \mathrm{k} \mathrm{m} 1 \mathrm{j}$ in dit onderzoek beperkt tot de gegevens uit $9 \overrightarrow{1}$ praktijken. De resultaten staan vermeld in tabel 5.1 .

Twee categorleèn: bevalling en consult vragen z⿺jn nauwe$11 \mathrm{jks}$ of niet wargenomen. Het heeft daarom geen $z i n$ ze verder als varlabele te gebruiken. 
Tabel 5.1. De gemiddelde relatieve tijdecores van de 41 observatie-categorieén over 91 huisartipraktijken.

\begin{tabular}{|c|c|c|c|}
\hline taakrubr lek & categorle & gentddelde & st.dev. \\
\hline \multirow[t]{5}{*}{ diagnostiek } & anamnese & 9.0 & 3.7 \\
\hline & $11 \mathrm{ch}$. ond. & 10.9 & 4.1 \\
\hline & elgen lab.ond. & 1.2 & 1.3 \\
\hline & ui tbest . 1ab. ond. & 0.7 & 0.5 \\
\hline & ud thest.dilagn. ond. & 0.6 & 0.5 \\
\hline \multirow[t]{4}{*}{ theraple } & medlcatie & 6.8 & 3.4 \\
\hline & advies & 3.0 & 1.5 \\
\hline & ther handeling & 2.3 & 1.7 \\
\hline & gesprek & 2.8 & 2.6 \\
\hline verwijzen & dHag. verwilgen & 1.0 & 1.2 \\
\hline \multirow[t]{3}{*}{ binnen } & ther verwijzen & 1.0 & 0.9 \\
\hline & cons.vragen & 0.3 & 0.6 \\
\hline & cons.geven & 0.1 & 0.2 \\
\hline verwljzen & verwijzen & 0.5 & 0.1 \\
\hline \multirow[t]{2}{*}{ butten } & 1nllcht .vragen & 0.1 & 0.3 \\
\hline & Inlicht -geven & 0.2 & 0.4 \\
\hline \multirow[t]{3}{*}{ begelelding. } & chron .cur. beg. & 4.7 & 3.3 \\
\hline & fo.1.10w-up & 1.1 & 1.3 \\
\hline & Inform geven & 0.2 & 0.4 \\
\hline \multirow[t]{6}{*}{ preventie } & geboortereg. & 2.7 & 2.2 \\
\hline & perinatale zorg & 1.1 & 1.4 \\
\hline & vaccinaties & 0.2 & 0.4 \\
\hline & $8 \cdot v \cdot 0$ & 0.1 & 0.3 \\
\hline & $P=g \cdot 0$ & 0.7 & 1.7 \\
\hline & survefliance & 0.4 & 0.8 \\
\hline \multirow[t]{10}{*}{ condttes } & organisatie & 5.4 & 4.2 \\
\hline & administratie & 4.1 & 3.6 \\
\hline & samenwerking & 2.6 & 3.4 \\
\hline & apotheek & 0.4 & 0.9 \\
\hline & telefoon & 5.8 & 3.8 \\
\hline & $\operatorname{retst} \mathbb{j d}$ & 11.4 & 5.0 \\
\hline & Boclaal contact & 2.9 & 2.8 \\
\hline & naschollng & 1.6 & 2.8 \\
\hline & onderwijs geven & 0.5 & 1.7 \\
\hline & prive & 10.7 & 7.6 \\
\hline \multirow{7}{*}{$\begin{array}{l}\text { andere acti- } \\
\text { viteiten }\end{array}$} & keuringen & 1.4 & 2.5 \\
\hline & graepsbegelelding & 1.3 & 3.5 \\
\hline & medisch adviseur & 0.1 & 1.0 \\
\hline & med. Indicaties & 0.1 & 0.2 \\
\hline & bestuursfunctle & 0.1 & 0.5 \\
\hline & andere arts act. & 0.4 & 1.7 \\
\hline & & 100.0 & \\
\hline
\end{tabular}


Van een paar categorieên $z 1 j n$ de aantallen per 100 arts-patiënt contacten berekend. Die categorleën zijn: eligen en ultbesteed laboratoriumonderzoek, ultbesteed diagnostisch onderzoek, verwijzlngen binnen de gezondheidszorg en medicat1e. De relatleve frequenties van deze activiteiten zeggen meer dan de relatieve t1jdsbestedingen. Het elgen laboratorlumonderzoek b1jvoorbeeld wordt meestal door de assistente verricht en de werkzaamheden van de assistente zijn nlet geobserveerd. In de relatleve tijdsbesteding aan eligen laboratoriunonderzoek zou dus een sterke vertekening zitten. Telkens als de hulsarts aangaf laboratoriumonderzoek te wilen verrichten hetzif in het eigen laboratorfum hetzij in het ziekenhuis, is dat door de observator als zodanig gescoord. Daarom is de relatieve frequentie van laboratorlumonderzoek in dit verband een aandulding van practische betekenis. De verwijsbrieven worden veelal na het spreekuur of 's avonds geschreven en de tijd, die aan het schrijven van recepten besteed is, zegt nog weinig over hoe valk medicamenteuze therapie gegeven wordt.

Als context-variabelen, dat wil zeggen, variabelen, die een aandulding geven van de werkomstandigheden, hebben we per huisarts de gemiddelde consultduur berekend en het gemiddeld aantal patiënten per observatie-uur.

De gemiddelde consultduur is de tijd besteed aan alle artspatiënt contacten tijdens spreekuren en visites gedeeld door het totale antal patiënten dat die huisarts tijdens de observatie heeft geholpen. Het gemiddeld aantal patienten per uur is het gemiddelde aantal patienten per observatie uur gedurende de observatiepertode per hulsarts. 
Tabel 5.2. De relatileve frequentles van 1 in antallen uitgedrukte bezigheden van de huisarts.

\begin{tabular}{lcc}
\hline & $\begin{array}{c}\text { gemidd./ } \\
\text { eigen lab.onderzoek }\end{array}$ & st.dev. \\
uitbest.lab.onderzoek & 6.7 & 5.0 \\
uitbest.diagn.onderz. & 4.5 & 3.1 \\
medicatie & 3.7 & 2.8 \\
verwijzingen & 50.5 & 13.1 \\
& 9.7 & 4.7 \\
gemidd.consultduur & $7.0 / \mathrm{min}$. & $1.6 / \mathrm{min}$. \\
gemidd.patiëntenaanbod & $6.0 / \mathrm{hr}$. & $2.2 / \mathrm{hr}$. \\
consult-visite ratio & 4.6 & 4.4 \\
\hline
\end{tabular}

Uit tabel 5.1. en 5.2. blijkt overduidelijk, dat de geobserveerde hulsartsen onderling sterke verschillen in hun activiteiten laten zien. Met name geldt dat ten aanzien van eigen laboratorium onderzoek, therapeutische handelingen, gesprek, verwijzingen, begelelding, geboorteregeling, perinatale zorg periodiek geneeskundig onderzoek, survelllance samenwerking, sociaal contact, nascholing, onderwijs geven, keuringen, groepsbegeleiding en consult-visite ratio.

De verschillen zijn geringer met betrekking tot anamese, lichamelijk onderzoek relstijd, medicatie, praktijkorganisatie en administratie, gemiddelde consultdurur en gemiddeld aantal patiënten per observatie-uur.

De verschilien zijn ongetwijfeld ten dele toe te schrijuen aan structurele factoren. Met name denken we dan aan de praktijkvorm, de patlëntenpopulatle, de plats waar gepraktiseerd wordt. Maar de verschlllen ten aanzien van gespreksvoering, sociaal contact, begeleiding, preventie en consult-visite ratio doen ons ook vermoeden, dat er individuele factoren in het spel zijn, bijvoorbeeld wat betreft de taakgerichtheid of het gedrag als hulsarts. In de volgende hoofdstukken zullen we daarom speclaal de aandacht richten op de individuele gerichtheld in taakuitoefening en de mate waarin situatie-, werkwijze- en persoonsvariabelen een verklaring geven voor de verschillen in taakuitoefening. Die situatie-, werkwijze- en persoonsvarlabelen worden daarom de onafhankelijke of verklarende varlabelen genoemd. 
5.3. De verklarende varlabelen.

$5 \cdot 3 \cdot 1$. Het verzamelen van gegevens.

Het literaturroverzicht ult hoofdstuk 2 heeft duidelijke aanwijzingen apgeleverd voor factoren die verschilien in de taakultoefening van huisartsen kunnen verklaren. Die factoren kurnen schematisch gerangschikt worden in:

- situatie-factoren, betrekking hebben op de werksituatie;

- werkw1jze-kenmerken;

- persoonskenmerken.

De meeste van de in het 1 iteratuuroverzicht besproken factoren heb ik in dit onderzoek gebruikt voor het bestuderen van de tweede vraagstelling. (zle 4.3.). De door mijgebrulkte verklarende varlabelen zijn:

Werksituatie:

- praktijkgrootte

- praktijkvorm

- zlekenfondsratio

- leeftijdsopbouw van de bevolking ter plaatse gemiddeld aantal patienten per observatie-uur

Werkw1jze:

- proportie uitbesteed laboratoriumonderzoek

- proportie verwijzingen

.- ultgebreidheid van het instrumentarlum

- consult-visite ratio

Persoon van de arts:

- ervaring als huisarts

- taakbreedte

- gewenst diagnostisch en therapeutisch niveau

- bereldheld tot samenwerking

- tijdisdruk en niveau van voorzlentingen

De wijze watrop deze gegevens verzameld zijn is als volgt: De praktijkkenmerken: praktijkgrootte, praktijkvorm en ziekenfondsratio zifn door de hulsartsen opgegeven, evenals het aantal jaren, dat men als hulsarts gevestigd is. Dat aantal faren is de operationalisatie voor het begrip: ervaring als huisarts. 
De demografische gegevens zijn overgenomen van het CBS. De bevolkingsopbouw in de plaats van vestiging is alleen geindiceerd met behulp van het aantal "kinderen jonger dan 14 jaar" als ratio van het totaal aantal inwoners. Door de vorm van onze bevolkingspyramide is er n.1. een signiflcante, hoge negatieve samenhang van deze variabele met de bejaarden ratio $(r=-.77, P<.01)$. We zouden 1 lefst de demografische samenstelling per praktijk hebben geweten, maar dat was niet haalbaar, omdat slechts weinig huisartsen over een leeftijd en geslachtsregister beschikken. Daarom is van een proxi gebruik gemaakt in de vorm van het CBS gegeven.

Het gemiddeld aantal patiënten per observatie-uur, de proportie ultbesteed laboratoriumonderzoek en verwijzingen en de consult-visite ratio zijn berekend uit de observatiegegevens $(5.2$.$) .$

Over de uitgebreidheid van het in de praktijk aanwezige instrumentarium is een vraag opgenomen in de enquête (vraag 11 , zile bijlage 2). Hieruit is een schaal geconstrueerd, lopend van zeer gering tot zeer uitgebreld. Zeer gering is, indien alleen een bloeddrukmeter, hechtset, oogsplegel en vaginaalspecula ter beschikking zijn (score: 4). Van zeer ultgebreid is sprake als daarbij zijn opgegeven: een audiometer, brillendoos, electrocardiograaf, een electronische stethoscoop, een hyfrecator, een peak-flow meter, een polarimeter, een rectoscoop, een tonometer. (score: 16).

De gespecificeerde taakbreedte, gewenst diagnostisch of therapeutisch niveau, bereidheid tot samenwerking en tijdsdruk en voorzleningenniveau zijn aspecten van opvattingen ten aanzien van de taken van de hulsarts. Bif de meting van opvattingen, die huisartsen hebben ten aanzien van de inhoud het niveau en de ultoefening van hun taken, z1jn we uitgegaan van de discussies rondom de verschillende takenpakketten zoals die opgesteld zijn door de LHV en KNMG-commissies. (zie hoofdstuk 1.1.).

De vragenlijst die voor deze meting gebruikt is, werd ook voorgelegd aan de representatieve steekproef van Nederlandse huisartsen. Op grond van de hieruit verkregen gegevens, hebben we geprobeerd enige structurering in het totale pakket vragen aan te brengen. Deze structurering willen we ook 
hanteren bij de verwerking wan de gegevens die bij de steekproef van geobserveerde huisartsen $\mathbf{z i j n}$ verkregen.

De meningen van hulsartsen omtrent de taakbreedte, tijdsdruk en voorzleningenniveau werden onderzocht op hun onderlinge samenhang. Hiertoe werd een associatie-matrix geconstrueerd met behulp van de maximale kapa (Cohen, 1970; H11debrand, 1977).

Door de wijze waarop deze maat wordt berekend kunnen ook scheve verdelingen en niet-linealre samenhangen in de analyse worden betrokken. Op de aldus verkregen assoclatie-matrix werd cluster-analyse uitgevoerd met behulp van het cluster-programma van Wishart (1978). Volgens de methode van clustering, te benoemen als hierarchisch, complete linkage (Everitt, 1974) werd hiermee het in tabel 5.3. weergegeven resultaat verkregen. 
Tabel 5.3. Cluster-indeling van opinievragen met betrekking tot de taakbreedte in de "grote" steekproef. $(\mathrm{N}=614)$.

clusterbenoeming

1. zelf soclale problemen aanpakken als huisarts

2. samenwerken met anderen

3. zo weinig moge$11 \mathrm{jk}$ doorverwijzen

4. zovee1 mogelijk zelf begeleiden en preventief werken

5. werken onder grote tijdsdruk

6. Voorzieningenniveau is vol doende voor begelelding en preventie
opinievragen (nr.
cluster-
uit vragenlijst,
niveau

zie bijlage 2

$12.4 \quad 12.6 \quad 15.7$

$\begin{array}{llll}12.4 & 12.6 & 15.7 & .135\end{array}$

$17.1 \quad 17.2 \quad 17.5$

$\begin{array}{llll}18.1 & 18.3 & 18.4 & .162 \\ 18.6 & 18.7 & \end{array}$

$\begin{array}{lll}12.5 & 13.1 & 13.5 \\ 14.5 & 16.3 & 16.4 \\ 16.5 & 17.3 & 17.4\end{array}$

$14.2 \quad 14.3 \quad 14.4$

.144

$14.6 \quad 15.1 \quad 15.2$

$15.5 \quad 15.6$

Enkele opmerkingen naar aanleiding van tabel 5.3.:

- De samenhang die gevonden 18 tussen de antwoorden op de onderschelden vragen is niet erg sterk te noemen (Boots, Van Zutphen, 1981). Gezien het felt dat de gebrulkte vragen betrekking hebben op binnen de beroepsgroep discutabele onderwerpen $z 1 j n$ twee conclusies mogeiljk:

ofwel de onderwerpen zijn alleen discutabel voor de kleine groep huisartsen in commissies en besturen van 
de beroepsverenigingen en niet voor de achterban; ofwel de discussie omtrent de verschillende onderwerpen is van dien aard, dat een mening op fén punt geen of nauwel1jks voorspellende betekenis heeft woor het ingenomen standpunt over een ander onderwerp.

- Het benoemen van de clusters is een arbitraire zaak. De nadere analyse die werd uitgevoerd op de tot clusters gegroepeerde variabelen is richtinggevend geweest. Deze vond plaats zowel met behulp van een per cluster opgestelde nulde-orde-correlatiematrix, als door onderlinge paarsgewijze vergelifking van de afzonderlifke vragen. De hieruit resulterende "bepalende" variabele werd voor benoeming vanult het cluster gekozen. Enige ondersteuning voor de clusters 1,2 en 4 wordt gevonden bif Raupp in de door hem gevonden factor II; factor III vertoont sterke gelijkenls met de clusters 5 en 6 (Raupp, 1971, p. 50). De taakopvatting van een huisarts zoals die door Dopheide (1982) is gemeten, betreft ultsluitend "verwijzen", een verdere splitsing van de vragen die in cluster 3 zijn samengevat.

- De gevonden clusters hebben op zichzelf weinig beschrijvende betekenis. We gebruiken ze om een empirische aanwijzing te hebben op grond warvan de gestelde vragen kunnen worden gegroepeerd en gebruikt voor een additieve schalconstructle van de gegevens, die verkregen zijn uit de steekproef.

Taakopvattingen.

De vragen warmee "opvattingen" van de geobserveerde hulsartsen ten aanzlen van taakbreedte, tijdsdruk en het voorzieningenniveau werden gemeten, zfjn samengevoegd volgens de clusterindeling die verkregen werd uit de enquêtegegevens van de representatieve landelijke steekproef. Na hercodering ten behoeve van de gelljke rlchting van alle antwoorden werden de scores opgeteld. De aldus ontstane elndscores vormen een ordinale schaal die tot een vijfpuntsindeling is getransformeerd op grond van het aantal samenstellende vragen. De vragen omtrent het gewenste niveau van diagnostiek en theraple zijn samengevoegd tot ordinale 
viffpuntsschalen.

Een "brede" taakopvatting wil zeggen, dat men bljvoorbeeld vindt, dat de hulsarts zo weinlg mogelijk moet doorverwijzen èn zo veel mogelijk begeleiding en preventle moet geven.

Hulsartsen met een "hoog" gewenst niveau van diagnostlek vinden dat de hulsarts zelf cardiale ritme stoornissen moet kunnen differentiëren, zelf een onderzoek moet doen naar de oorzaken van infertiliteit e.c.g.'s moet kunnen lezen en psychomotore ontwikkelingsstoornissen bij kinderen moet kunnen vaststellen.

Een "hoog" gewenst therapeutisch niveau betekent bifvoorbeeld dat men vindt zelf paracentese te moeten doen, een bril voor presbyople of 11 chte myopie te moeten voorschrijven of zelf patiënten met een allergie te moeten desensibiliseren.

Een "grote" bereldheid tot samenwerking met andere eerstelijns werkers wil zeggen, dat men bijvoorbeeld vindt dat gestructureerd samenwerken met anderen een noodzakelifke voorwaarde is voor een kwalitatief verantwoorde zorg of dat in een samenwerkingsverband de specifieke taak van de huisarts beter tot $z i j n$ recht komt. 
Tabe1 5.4. Frequentieverdeling in percentages van de antwoorden op de vragen naar taakopvatting.

\begin{tabular}{|c|c|c|}
\hline & $\begin{array}{l}\text { laag } \\
\text { positief }\end{array}$ & $\begin{array}{l}\text { hoog } \\
\text { positief }\end{array}$ \\
\hline zelf sociale problemen aanpakken & 38.7 & 16.1 \\
\hline bereldheid tot samenwerken & 21.5 & 37.6 \\
\hline $\begin{array}{l}\text { zo weinig mogelijk doorverwijzen } \\
\text { zo veel mogelijk begelelding/ }\end{array}$ & 1.1 & 83.9 \\
\hline preventle geven & 6.5 & 38.7 \\
\hline $\begin{array}{l}\text { t1jdsdruk is belemmerend } \\
\text { voldoende ondersteuning door }\end{array}$ & 44.1 & 19.4 \\
\hline anwezlige voorzieningen & 11.8 & 52.7 \\
\hline $\begin{array}{l}\text { gewenst niveau van somatische } \\
\text { dlagnostiek }\end{array}$ & 7.5 & 49.5 \\
\hline $\begin{array}{l}\text { gewenst niveau van somatische } \\
\text { therapie }\end{array}$ & 1.1 & 79.6 \\
\hline
\end{tabular}

De verdelingen laten zien dat de meningen redelijk gespreid zijn.

- Een negatieve tendens valt de constateren ten aanzien van het zelf aanpakken van sociale problemen en een meer positieve houding ten aanzien van het zo weinig mogelijk doorverwijzen.

- Meer verrassend is de ontkenning van de tijdsdruk als belemmerende factor bij het uitoefenen van de taken als hulsarts. Waarschijnlijk hangt dit samen met de koppeling die in de betreffende vragen wordt gelegd tussen de tijdsruk en het gewenste niveau van handelen per functie. Het aangeven van tijdsdruk zou betekenen: beneden het na te streven kwaliteitsnivaeu werken.

Het noodzakelifk geachte niveau van diagnostiek en theraple is hoog. Hoewel de vragen hleromtrent voor het merendeel "facultatleve" taken uit het takenpakket van de LHV-commissle bevatten, zegt toch het merendeel van de ondervraagde huisartsen dat deze activiteiten tot het werkgebled van de huisarts behoren.

Wanneer we de beschrijvende gegevens uit tabel 5.4. globaal samenvatten dan kan gezegd worden: 
De hulsartsen achten een hoog niveau van somatische diagnostiek en therapie wenselijk, ze zijn gericht op zelf begeleiden, preventilef werken en zo weinig mogelijk doorverwijzen. Ze voelen zich niet erg gehinderd door tijdsdruk, ook niet door ontbrekende voorzieningen. Over samenwerking met andere eerstelijns werkers lopen de meningen zeer sterk uiteen, met een zeer licht overwicht naar de positieve kant.

5.3 .2 . Overzicht van de gemiddelde warden en standaarddeviaties van de verklarende varlabelen.

A. Varlabelen met betrekking tot de werksituatle.

1. De praktijkgrootte per huisarts: $\bar{x}=2935$ pat., s.d. $=1174$.

2. De praktijkvorm per huisarts; een dichotome variabele: solistisch $(62,4 \%)$ en non-solistisch $(37,6 \%)$.

3. De zlekenfondsratio: het aantal ziekenfondspatienten als proportie van het totaal antal ingeschreven patiënten per hulsarts: $\bar{x}=0,676, s . d .=0,162$.

4. De ratio van het aantal kinderen onder de 14 jaar ten opzichte van de totale bevolking van de gemeente waar de hulsarts praktiseerd: $\bar{x}=0,242$, s.d.= 0,044 .

5. Het gemiddeld aanta1 patiẻnten per observatie-uur per hulsarts: $\bar{x}=6,0$, s.d. $=2,2$.

B. Variabelen met betrekking tot de werkwijze.

6. De proportle uitbesteed laboratoriumonderzoek: het aantal onderzoeken per 100 patiëntencontacten in de observatieperiode per hulsarts: $\bar{x}=4,5, \operatorname{s.d}=3,1$.

7. De proportie verwijzingen: het aantal verwijzingen per 100 patiëntencontacten in de observatieperiode per hulsarts: $\bar{x}=9,7$, s.d. $=4,7$.

8. De uitgebreidheid van het instrumentarium: een ordinale schal, samengesteld uit de antwoorden op vraag 11 uit de vragenlijst (zie bijlage 2) oplopend in schaalwaarden van "zeer gering" tot "zeer ultgebreid" : $\bar{x}=9,6$, s.d. $=2,6$.

9. De consult visite ratio: de verhouding tussen het in de observatieperlode per hulsarts wargenomen 
aantal spreekuurconsulten en de bezoeken bij de patiènt thuis: $\bar{x}=4,6, s . d .=4,4$.

C. Vartabelen met betrekking tot de persoon van de hulsarts.

10. De ervaring als hulsarts: ultgedrukt in het aantal jaren prakt1jkervaring per hulsarts: $\bar{x}=11,2$, s.d.= 8,7 .

11. De taakbreedte per hulisarts: uitgedrukt in een vijfpunts ordinale schaal, samengesteld uit de clusters 1,3 en 4 (zie tabel 5.3.) oplopend in schaalwaarden van "smal" naar "breed" en met een betrouwbaarheidscoëfficient $\alpha=.54$. $\bar{x}=2,9$, s.d.= 1,5 .

12. Het gewenste diagnostische en therapeutische niveau: een vijfpunts ordinale schaal, samengesteld u1t de vragen van paragraaf $20 \mathrm{~A}$ en $20 \mathrm{~B}$ uit de vragenlijst (zie bijlage 2) in schaalwaarden oplopend van "laag" naar "hoog" en met een betrouwbaarheidscoëfficlent $\alpha=.67 . \bar{x}=3,0, s . d .=1,4$.

13. De bereidheid tot samenwerking in het eerste echeIon: een vijfpunts ordinale schaal, gebaseerd op de vragen in cluster 2 (zie tabe1 5.3.) oplopend in schaalwaarden van "weinig bereidheid" tot "grote bereldheld" en met een betrouwbararheidscoëfficient van $\alpha=.48 . \bar{x}=2,9$, s.d. $=1,5$.

14. De beschikbare tifd en de beschikbaarheid van ondersteunende voorzieningen: een vijfpunts ordinale schaal, samengesteld uit de clusters 4 en 5 (zie tabel 5.3.), oplopend in schaalwaarden van "weinig" tot "veel" en met een betrouwbaarheidscoëfficlent van $\alpha=.57 . \bar{x}=3,0, s . d .=1,5$. 
Hoofdstuk 6. De taken van de hulsarts.

\subsection{Inleiding.}

In dit hoofdstuk staat de eerste van de twee voor dit onderzoek geformuleerde vraagstellingen centraal. Die vraag luidt: welke taakdimensies zijn er feltelijk te vinden in de activiteiten, die huisartsen dagelifks verrichten, met andere woorden op welke taken is het werk van de hulsarts de facto gericht?

Bij de behandeling van deze vraagstelling speelt de factoranalyse een belangrijke rol. Met factoranalyse kan men een ordening geven van de relatieve tijdsvariabelen, dus van de observatie-categorleën, in taakdimensies of factoren, die een op statistisch-empirische gronden nauwkeuriger met de werkelijkheid overeengekomende afspiegeling van de taakstructuur opleveren dan de schematische indeling van de observatie-categorieën uit de door de beroepsgroep opgestelde taakrapporten. Met de factoranalyse verkrijgen we bovendien een reductie in het betrekkelijk grote aantal tijdsvariabelen, hetgeen noodzakelijk is voor de behandeling van de tweede vraagstelling, die beschreven wordt in hoofdetuk 7 .

In paragraaf 6.2. zal de bewerking met de factoranalyse beschreven worden.

In paragraaf 63 . wordt de inhoud van de empirisch gevonden takstructuur besproken.

In paragraaf 6.4 . wordt de relatie tussen de gevonden factoren en het door de Landelijke Huisartsen Vereniging geformuleerde "Basis-Takenpakket van de Huisarts" bediscussieërd (LHV, 1983).

\subsection{De factoranalyse.}

Het staat bij voorbat vast, dat een aantal van de tijdsvariabelen niet onafhankelijk van elkaar is en dus met elkaar samenhangt. Het zal duldelijk zljn dat bijvoorbeeld anamnese, lichamelijk onderzoek, medicatie en advies een signif1cante samenhang met elkaar vertonen.

Hetzelfde geldt voor bijvoorbeeld vacclnaties en zulgelingencontrôles. Uit de correlatiematrix van de tijdsvarlabelen 
(zle bijlage 3) blijkt dan ook dat er talrijke significante correlaties bestaan tussen de 41 tijdsvarlabelen.

Met behulp van factoranalyse kan men nu een inzicht krijgen in de verschillende samenhangen. Factoranalyse is een statistische methode, warbij gebrulk gemaakt wordt van matrixalgebra en waarmee een groot aantal onderling samenhangende, kwantitatieve variabelen omgezet wordt in een beperkt aantal nieuwe "varlabelen" of factoren. Die factoren worden gewoonlijk zo gekozen, dat ze onafhankelijk van elkaar zijn. Het gaat er om een beperkt aantal factoren te vinden, die de achterliggende structuur in de data zo kernachtig mogelijk weergeeft. Men veronderstelt daarbij, dat twee verschillende bronnen van invloeden aan de totstandkoming van de gegevens hebben bijgedragen, namelijk gemeenschappelijke en unieke invloeden. De gemeenschappelijke invloeden maken, dat er samenhang tussen de empirische variabelen valt te constateren. De unleke invloeden nemen de overblijuende verschlllen of variantie in de gegevens voor hun rekening, onder andere die ten gevolge van meetfouten. vanuit de correlatiematrix kan men dus met factoranalyse zoeken naar systematlek in het mozalek van samenhangen tussen de gemeten variabelen. Die systematiek is te vinden door van elk paar variabelen te bepalen hoe sterk hun samenhang is en die uit te drukken in een zogenaamde factorlading. De waarde van die factorlading kan variëren van 0 (laagste lading) tot +1 of -1 (hoogste lading). Een hoge lading betekent dat de varlabele veel informatie met de betreffende factor deelt. Factoren zijn eigenlijk wiskundige vergelljkingen, die pas betekenis krijgen door de interpretatie, die men er aan geeft. Men moet de factoren benoemen. Om ze zinvol te kunnen benoemen moet men een niet te groot aantal factoren trekken. Anderzljds moet dat aantal niet te klein zijn, want behalve de eis, dat de getrokken factoren goed benoembaar moeten zijn, moet er rekening mee gehouden worden, dat de factoren in voldoende mate de varlantie in de variabelen voor hun rekening nemen. Er zou anders bij de reductle van het oorspronkelijke aantal variabelen te veel informatie verloren gaan. In dit onderzoek stellen we ons ten doel, dat de factoren stuk voor stuk voor een elgensoortige bron van variantie staan èn dat ze tegelljkertifd een hoge practische betekenis hebben. Ten aanzien van het te trekken aantal factoren houdt dat het sluiten van compromissen in. Dikwijls zal op een punt 
moeten worden ingeleverd om op een ander punt te winnen (Van der Zee, 1975).

Bij de extractie van factoren spelen twee overwegingen dus een belangrijke rol. In de eerste plaats dient met de factoren aanzienlijk meer informatie te worden gegeven dan met de afzonderlijke variabelen. Hier hebben we te maken met 41 variabelen, dat 11 zeggen dat elke varlabele gemiddeld ongeveer $2,5 \%$ van de beschikbare informatie voor zijn rekening neemt. Een factor moet daarom veel meer dan $2,5 \%$ van de variantie verklaren. Als dat percentage niet veel groter is dan verliest die factor zijn practische betekenis.

In de tweede plaats moet men beslissen of men de voorkeur geeft aan zoveel mogelijk gebonden varlantie per factor of aan een zo hoog mogelijke lading op de factoren per variabele. Zojuist is al gezegd dat wij in dit onderzoek streven naar zo veel mogelijk variantie per factor. We hebben daartoe bij het trekken van de factoren gebrulk gemakt van de varimax-rotatie in het SPSS-programma (Nie et al., 1975). Bij het kiezen van het voor het gegeven doel, passende aantal factoren zijn er een par criteria, die houvast bieden. Dat zijn:

- de communaliteit: het percentage verklaarde variantie per variabele;

- het percentage verklaarde variantie per factor;

- het percentage totaal verklaarde varlantle door alle factoren tesamen.

De communaliteit is een mat, die ultdrukt hoeveel variantie van een varlabele door de factoren tesamen wordt verklaard. Deze maat wordt berekend door alle bij een variabele behorende factorladingen te kwadrateren en te sommeren. De som kan maximaal 1.0 worden. De hoogte van de communalitelt zegt lets over de mate, warin de factoren er in slagen een variabele te vervangen.

Factoranalyse is dus een methode van speuren naar famllies van variabelen in een bestand van onderling samenhangende variabelen. In paragraaf 3.4 . Is reeds vermeld, dat w bij de indeling van de observatie-categorleën zijn ultgegaan van een schematische indeling van de taken van de hulsarts, gebaseerd op het LHV-rapport: De Taken van de Hulsarts" (LHV, 1977). Onze indeling omvat zes patiëntenzorgtaken en twee aanvullende taken, waarvan er én is samengevat als "condities" (= voorwaarden-scheppend), waartoe werkzaamhe- 
den ten behoeve van de praktijkvoering en het functioneren als hulsarts worden gerekend en de ander als "andere activiteiten als arts". Zou die indeling juist zijn, dus met de werkel1jkheld overeenkomen, dan zouden wij hier nu de voorspelling van die taakstructuur kunnen toetsen door de computer acht factoren te laten trekken en dan zien of er acht goed benoembare factoren tevoorschijn komen. Dat is gebeurd. In alle gevallen is een factorlading van .30 of groter aangehouden om een varlabele een bijdrage te laten leveren aan de 1 inhoud van de betreffende factor.

Van de acht factoren was de eerste goed benoembaar. Daarnaast waren er nog vier factoren redelijk benoembaar. Eén factor was vooralsnog niet duldelljk en de laatste was niet benoembaar. Dus de door ons veronderstelde taakstructuur klopt niet met de werkelijkheld. Wel geeft dit resultaat een Indicatie, dat er warschijnlijk zes goed benoembare factoren in thet materlaal te vinden $z i j n$.

De factoranalyse is daarom herhaald, warbij de extractie na zes factoren beëlndigd is. De uitkomst van deze factoranalyse is weergegeven in de tabellen 6.1. en 6.2. 
Tabel ractorladingen on communalltedt van ar. 1 toljow varlabelem op do getrokiken factorm.

\begin{tabular}{|c|c|c|c|c|c|c|c|}
\hline Tljasivar. & $F 1$ & 2 & 3 & E & Fi & 56 & Gom: \\
\hline anamnese & .22 & 21 & $x-14$ & +14 & -.05 & .00 & .60 \\
\hline lich. ond. & .71 & -.00 & -.18 & .03 & -.27 & -.05 & .57 \\
\hline eigen lab. & -.03 & .00 & -.02 & -.03 & .00 & $=-30$ & .10 \\
\hline ndet-elgen lab & .53 & .15 & .13 & .24 & .99 & -.95 & .39 \\
\hline aangevr "alagn: & 41 & -.11 & -.05 & -.09 & -.07 & .04 & .20 \\
\hline medicate & .62 & -.17 & .27 & -.08 & .27 & .06 & $E 2$ \\
\hline advies & .36 & -.13 & -.34 & .45 & .22 & .04 & $=51$ \\
\hline ther "hamae $1 \mathrm{ng}$ & .31 & -.03 & -.21 & .07 & -.07 & -.04 & 16 \\
\hline ther wesprek & .05 & .15 & -.05 & -.07 & -.20 & +31 & 19 \\
\hline diagn. varwitz. & .00 & -.03 & .18 & -.01 & .00 & .06 & .04 \\
\hline ther. werw 1 I $z$. & .38 & .12 & .01 & -.47 &.$\$ 5$ & -.13 & .42 \\
\hline consult vregen & -.12 & .06 & .55 & .14 & -.02 & .06 & .35 \\
\hline consult geven & ט09. & .03 & -.05 & .27 & -.01 & .14 & $\times 10$ \\
\hline verw bulten gez.z. & -.04 & .37 & .06 & -.07 & $\times 8$ & -.01 & $\mathbb{1} .5$ \\
\hline In lehtingen geven & -.20 & .24 & -.13 & -.03 & -11 & .12 & .14 \\
\hline In 1 chtingen vragen & -.09 & .20 & .02 & -.04 & .19 & .25 & 15 \\
\hline chron cur bege leld. & -.09 & -.26 & .15 & .27 &.- .41 & -.16 & .36 \\
\hline follow up & .13 & -.13 & -.12 & -40 & -.16 & .02 & .23 \\
\hline Informatie geven & -.00 & -.20 & -.10 & -.05 & $\stackrel{48}{\longrightarrow}$ & $\times 14$ & 31 \\
\hline geboorterege ing & .09 & .04 & -.30 & .24 & .40 & -.13 & .3 \\
\hline perinatale zorg & -.27 & .05 &.- .37 & .20 & -.00 & .25 & .3 .1 \\
\hline vacolneren & -.13 & -.43 & -.13 & .09 & .36 & .18 & .39 \\
\hline per. gen. ond. & .05 & -.42 & $-\ldots .05$ & -.12 & -.05 & .10 & .20 \\
\hline gurve 11 lance & .01 & -.13 & .05 & .37 & .18 & -.98 & .20 \\
\hline get. voorl. en opv. & .01 & .03 & -.08 & .26 & -.14 & -.05 & .13 \\
\hline prakt 1 jkorgandsat de & -.25 & -.18 & -.33 & -.09 & -.01 & .20 & .25 \\
\hline adm/reglistratle & -.09 & .33 & -.03 & -.48 & .00 & -.26 & .42 \\
\hline telefoon & .07 & .315 & -.06 & -.15 & -.36 & .24 & .22 \\
\hline wpotheek & -.09 & .09 & -.02 & -.14 & -.14 & -.06 & .36 \\
\hline sarienwerking & -.04 & 33 & .00 & .07 & -.28 & .15 & .22 \\
\hline relstud & -.12 & -.56 & .23 & .01 & -.14 & .08 & $\cdot 4 d$ \\
\hline social contact & -.14 & -.21 & .29 & .05 & -.15 & -.11 & .16 \\
\hline naschollng & -.08 & .06 & .44 & $=.07$ & .29 & .05 & .3 \\
\hline anderw 1 is grwen & -.38 & .38 & .25 & .00 & .03 & .17 & .30 \\
\hline kevrlingen & .09 & .01 & 28 & -.09 & .08 & -.25 & $* 15$ \\
\hline categor. bege L. & -.30 & -.13 & -.10 & .10 & .33 & .29 & .39 \\
\hline priwé & -.56 & 11 & -.05 & .02 & $\therefore .01$ & -.52 & .61 \\
\hline med. Indicatie & -.07 & -.08 & 36 & .26 & -11 & .92 & .25 \\
\hline med adviseun & -.13 & .01 &. .03 & -.02 & -.26 & $=.06$ & .14 \\
\hline and. atsact $\mathbb{H}$. & -.24 & .12 & .00 & -.02 & .04 & .28 & .15 \\
\hline 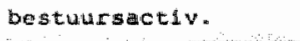 &.$- O B$ & $=.01$ & .06 & .10 & .17 & $.2 \$$ & $.0 \%$ \\
\hline
\end{tabular}


Tabel 6.2. De per factor verklaarde varlantie en het door de zes factoren totale percentage verklaarde varlantle.

$$
\% \text { per factor cum. } \%
$$

$\begin{array}{lrr}\text { factor } 1 & 9,6 & 9,6 \\ \text { factor } 2 & 6,8 & 16,5 \\ \text { factor } 3 & 6,0 & 22,4 \\ \text { factor } 4 & 5,5 & 27,9 \\ \text { factor } 5 & 4,7 & 32,6 \\ \text { factor } 6 & 4,5 & 37,2\end{array}$

Het b11jkt dat de zes factoren samen $37,2 \%$ van de totale varlantle verklaren. Dat is hoog in aanmerking nemend, dat het om observatle-onderzoek gaat. In observatiegegevens zit onvermijdelijk veel "ruis". Gedrag is nu eenmal weerbarst1g. Hiermee rekening houdend hebben we als grens voor de communalitelt de waarde .15 aangehouden. Daarmee blijkt, dat de zes factoren 33 van de 41 variabelen kunnen vervangen; dat 1 s $80 \%$. De tijdsvarlabelen met unieke variantie zijn:

- eigen laboratorlumonderzoek;

- diagnostisch verwijzen;

- gezondheidsvoorlichting en -opvoeding;

- Inlichtingen geven aan andere hulpverleners;

- consultatie geven;

- medisch adviseurschap;

- a potheekwerkzaamheden;

- bestuursactiviteiten.

Deze activiteiten behoren dus tot een rest die geen aan de zes factoren gerelateerde betekenls heeft. Waarschijnlijk komt dit door het felt dat de huisarts aan deze activiteiten weinig tijd blifkt te besteden, zoals aan gezondheldsvoorlichting en -opvoeding, consultatie geven en inlichtIngen verstrekken an andere hulpverleners (zie 5.2.; Bergsima, 1984), of ze gewoonlijk an de assistente overlaat, zoals laboratortumonderzoek in de elgen praktijk en apotheekwerkzaamheden (Raupp, 1971). Bestuursactiviteiten en medisch adviseurschap blifken overdag in de werktijd vrijwel niet voor te komen (zie 5.2.). Het door ons gemaakte onderscheld in verwijzen met overwegend diagnostische vraagstelling blijkt van geen betekenls. Op bovenstaande 
gronden blijkt een factoranalyse met zes factoren het meest aan de doelstelling van goede benoembaarheld van de factoren en een zo groot mogelijke mate van verklaarde varlantie te beantwoorden.

Factor 1 blijkt voornamelijk te worden bepaald door de varlabelen gerangschikt onder "diagnostiek", "theraple" en "verwijzen binnen de gezondheidszorg". Opvallend is, dat "prive" ( $t$ ljd besteed aan pauzes en persoonlijke bezigheden), "groeps- of categorale begeleiding" en "advies geven" en het "geven van onderwijs" een hoge negatieve lading hebben. De perinatale zorg heeft eveneens een relatieve hoge, negatieve lading $(-.27)$. Behalve dus dat deze factor onmiskenbaar verwijst naar de somatische curatieve zorg, is er tevens een aanwijzing, dat huisartsen, die meer dan een gemiddelde hoeveelheid tijd aan curatieve zorg besteden druk in beslag genomen worden door hun praktijk, en geen gelegenheid vinden om naast hun werk nog extra-taken te vervullen, zoals een huisarts-opleiderschap, het doen van consultatiebureau's voor zulgelingen en kleuters of verloskundige zorg. In sommige gevallen kan dit gedrag samenhangen met structurele omstandigheden. In de grote stad bijvoorbeeld doet de hulsarts minder aan verloskunde en aan zuigelingencontroles (Bremer, 1978).

Factor 2. Op deze factor laden hoog positlef: "verwijzen buiten de gezondheldszorg", "samenwerking met andere disciplines" "administratie en registratie", "telefoon" en "het geven van onderwijs". Ook hier zijn er een aantal categorieën die tamelijk sterk negatief laden: "relistijd" (vervoer), "vacclnaties" en "periodlek geneeskundig onderzoek". De combinatie "vaccinaties" en "periodiek geneeskundige onderzoek" wil zeggen het verrichten van zulgelingen- en kleuterzorg ten behoeve van kinderen uit de elgen prakt1jk, al of niet uitgevoerd op een apart baby-spreekuur. Deze factor wijst op samenwerking met andere disclplines en het geven van onderwijs. Het verband tussen samenwerking en onderwijs geven is niet direct voor de hand 1iggend. Samenwerken komt voort uit methodisch werken (Holten-Vriesema et al., 1978). Methodisch werken en administratie en registratie (verslaglegging) zijn belangrijke uitgangspunten voor 
het practisch medisch onderwijs en de beroepsopleiding tot huisarts (Bouhuijs, 1983; R1jntjes et al., 1983; Van Aalderen, 1980). Het is daarom denkbaar, dat men door het doelgerlcht samenwerken met andere disciplines zich ook aangesproken voelt on als hulsartsoplelder te fungeren. Ook het omgekeerde $1 \mathrm{~s}$ mogelijk, dat men als huisartsopleider in de tralning, die daar bij behoort, het samenwerken met andere disciplines julst ontwikkelt. Hoe het ook zij een zeker gedrag als hulsarts hangt hiermee samen, namelljk een meer dan gemiddelde tijdsbesteding aan samenwerking en onderwijs geven gaat gepaard met een "modernistische" stijl van praktijkwoering, in de zin, dat er relatief welnig hulsbezoeken worden afgelegd.

op factor 3 laden redelijk hoog positief: "nascholing", "consultatie vragen" en "medische indicatiestelling" en negatief de categorieën: "praktijkorganisatie", "perinatale zorg", "geboorteregeling" en "advles". Deze factor verwijst daarmee naar het vergaren van gegevens en inlfchtingen ten behoeve van de patientenzorg en het op pell houden of het vergroten van de eigen deskundigheid als huisarts.

"Soclaal contact" laadt eveneens redelijk hoog (.29) op deze factor hetgeen er op duidt dat nascholing en ziekenhuisbezoek samengaan. Onder de categorle "sociaal contact" is immers onder andere het bezoek van patiënten in het zlekenhuis geregistreerd. Dat lijkt zeer aannemelijk; klinische bijeenkomsten en patiëntendemonstraties zijn een belangrijke vorm van nascholing voor hulsartsen. Het relatief meer tijd besteden aan nascholling en aan consultatief overleg met specialisten gat kennelijk vaak samen met een relatief groter tijdsbesteding aan het opzoeken van patienten in het ziekenhuis.

Factor 4 wordt voornamelijk bepald door de negatlef ladende categorieèn: "(therapeutisch) verwijzen", "follow-up" (nazorg) en "administratle/registratie". In positleve zin wordt deze factor bepald door: "advies" en "survelllance". Dit wist in de richting van de secundalr-preventieve begelelding van risico-patiënten. Deze interpretatie wordt gesteund door de tamelljk hoge samenhang van deze factor met de varlabele "curatieve begeleiding".

Een relatief geringe tijdsbesteding aan verwijzingen hangt samen met een relatief grotere tijdsbesteding aan surveil- 
lance van risicopatiënten en het begelelden van chronisch zieken.

Op factor 5 laden de categorieën: "chronisch curatieve begeleiding" en "informatie geven" sterk negatief. Positlef laden: "geboorteregeling", "vaccinaties" en "categorale- of groepsbegeleiding". Dit laatste betreft voornamelijk zuigelingen- of kleutercontrôles op consultatlebureaus. Deze factor is te omschrijven als preventie ten behoeve van vrouwen in de fertiele leeftijd en van jonge kinderen. opvallend is dat "samenwerking" en "gesprek" negatief en "medicatie" betrekkelijk hoog positief laden op deze factor. Een meer dan gemiddelde tijdsbesteding aan primaire preventle aan vrouwen in de fertiele leeftijd en aan jonge kinderen gaat gepaard met een relatief geringere tijdsbesteding aan samenwerking met andere disciplines en gespreksvoering. Het zou kunnen $z i j n$, dat dit gedrag samenhangt met een meer somatisch-technische instelling.

Factor 6 wordt in de eerste plaats gekenmerkt door een hoge negatieve lading van de categorie: "prive" en in de tweede plaats door de hoge positieve lading van "gesprek". Deze factor wijst naar de dimensie therapeutische gespreksvoering. Een relatief sterke positieve lading van de categorieën: "perinatale zorg" en "inlichtingen vragen aan andere hulpverleners in het eerste echelon" steunen mijns inziens die interpretatie. De perinatale zorg omvat ook de opvang van de vrouw na de bevalling. Gezlen de frequentie van voorkomen van post-partale depressies (Sanders, 1984) zal er zeker behoefte bestaan aan gespreksmatige begelelding. Uiteraard kan die behoefte ook op andere terreinen aanwezig z1jn of kunnen hulsartsen het geven van gespreksmatige interventie gelndiceerd achten.

Het is in leder geval duldelijk, dat wanneer de hulsarts relatief vaker tot gespreksvoering overgaat hem dat veel tijd kost en hij die tijd moet zien te verkrijgen door langer te werken en zich minder pauzes te gunnen.

Dus niet alleen artsen met een relatief grotere tijdsbesteding aan somatisch curatieve zorg werken onder een grotere tijdsdruk. Bij de gespreksvoering treedt dat verschijnsel eveneens op. 
6.3. Bespreking van de resultaten.

In $d 1 t$ onderzoek is aan het trekken en benoemen van factoren de eis gesteld, dat de factoren een hoge practische betekenls moeten hebben om de doelstellingen, die de hulsarts in $z 1 j n$ werk tracht te berelken te kunnen aangeven. Dat betekent, dat de factoren leder voor zich een elgensoortige bron van variantie moeten vertegenwoordigen, dat zil zeggen dat ze zich zoveel mogelijk onafhankelijk tot elkaar verhouden. De kwallteit van onze factoren is af te meten aan twee soorten criteria: interne en externe criteria.

Interne criteria zeggen of de representatie in de factoren recht doet aan het empirisch materiaal. Dit wordt afgemeten aan de communaliteft, het percentage verklaarde varlantie per factor en het door de factoren tesamen verklaarde percentage van de totale varlantle. Het percentage totaal door de factoren verklaarde variantie is hoog, de aard van het onderzoek in aanmerking nemend. Voor de communaliteit is hier een warde .15 gekazen. Bij deze waarde vervangen de zes factoren 33 van de 41 varlabelen. De vartabelen, die niet zijn vervangen blijken een ondergeschikte, niet noemenswaardige rol te spelen in het werk van de hulsarts (zle tabe1 6.3.$)$.

Tabel 6.3. De tien categorleën met de hoogste en de laagste waarde van communaliteit.

hoogste communaliteit

\begin{tabular}{ll}
\hline anaminese & .60 \\
lich.ond. & .57 \\
medicatie & .52 \\
advies & .51 \\
prive & .61 \\
relstijd & .41 \\
verslaglegging & .42 \\
vacclneren en & \\
cat.begeleiding & .36 \\
chron.cur.beg. & .36 \\
onderwijs geven & .38
\end{tabular}

laagste communaliteit diagn.verw. $\quad .04$ apotheek .06 bestuursact. .07 med.adv. .10 g.v.o. .10 consult geven $\quad .10$ elgen lab. ond. $\quad .10$ verw.buiten gez. zorg .15 1nl. geven $\quad .14$ nevenfuncties $\quad .15$ (keuringen en andere artsact.) 
Aan interne criteria afgemeten is dus het resultaat aanvaardbaar en bevredigend te noemen.

De externe criteria hebben te maken met het zoeken naar een theoretische en practische rechtvaardiging.

We beschikken nlet over resultaten van soortgelijk in ons land uitgevoerd onderzoek.

Bij de 1 iteratuurverkenning in hoofdstuk 2 konden we wel een zekere aanduiding van een taakstructuur in het werk van de huisarts verkrijgen, echter uit onderzoeken, die of 1 n Eenmanspraktijken hadden plaatsgevonden of in een representatieve steekproef maar met telkens andere doelstellingen of methoden. De aanduiding berust niet op aangetoonde samenhang. Dat maakt het trekken van vergelijkingen met $\mathrm{m} I j n$ onderzoeksresultaat niet zinvol.

De Nederlandse huisarts is nog het best te vergelijken met de Engelse, maar de ondernomen tijdstudies naar het werk van die hulsarts hebben meestal betrekking op de verhouding tussen spreekuren, huisbezoeken, of op verrichtingen zoals aantallen recepten, verwijzingen of verrichtingen ten behoeve van categorieën van patiënten naar geslacht en leeftijd (Hul1, 1983; Morrel1 et a1., 1970; Richardson et a1., 1973; Knox et al., 1984; McGregor, 1973; Wilson, 1982). Ook die gegevens zijn moellijk met mijn onderzoek vergelijkbaar. Voor de externe criteria zijn we daarom afhankelijk van face-validity, dat wil zeggen 1 ijken de resultaten plausibel en realistisch op basis van common sense. Dit betekent dat we de resultaten moeten toetsen aan de hand van ervaring met de praktijk.

De zes gevonden factoren zijn te groeperen naar:

a. directe patiëntenzorgdoelen;

b. een voor de patiëntenzorg voorwaardelijk doel.

Onder de eerste groep zijn te rangschlkken:

- factor 1: de curatieve zorg;

- factor 4: de secundalre preventie en begelelding van risico-patiënten en chronisch zleken;

- factor 5: de primaire preventie van vrouwen in de fertiele leeftijd en van jonge kinderen;

factor 6: de (therapeutische) gespreksvoering. Onder de tweede groep vallen:

- factor 2: het samenwerken met en verwijzen naar andere hulpverleners en het geven wan onderwijs; 
- factor 3: het inwinnen van inlichtingen en advies voor de patientenzorg, het verbeteren of op peil houden van de vakbekwaamheid door middel van naschollng.

Wat de vallditelt van factor 1 betreft stellen er zich geen moellijkheden. Het is evident, dat curatleve zorg in de vorm van diagnostlek, theraple en verwijzen naar specia14sten de belangrijkste dimensie in het werk van de huisarts is.

De secundaire preventie van risicopatiënten geeft al evenmin problemen in de zin dat dit streven als logisch voorkomt en omdat bekend is, dat diabetici, hypertonici. carapatienten, bejaarden en dergelijke van de huisarts speciale zorg krijgen (A. Seelen et al., 1980; Van Weel, 1981; Van den Doo1, 1970; Boot, 1979; Van Ree, 1980; Brouwer, 1982; W11lemse, 1981).

De primaire preventie van zulgelingen en kleuters is een erkende taak, die dikwijls in het kader van de consultatiebureaus van de Krulsverenigingen wordt verricht. Sinds de grote vlucht van het gebruik van orale anticonceptie is de zogenaamde pilcontrôle een integraal deel van het werk van de hulsarts geworden (Bremer, 1978; Huygen, 1981). Deze factor geeft daarom op juiste wijze een pijler uit het werk van de hulsarts weer.

De (therapeutische) gespreksvoering komt hier niet als een sterke factor uit. Doch uit de ervaring is het ledereen duldelifk dat de gespreksvoering een aparte taak is van de hulsarts (Oosterhuis, 1972; Elting, 1972; Bremer, 1978). Er doen alch geregeld situaties voor die de huisarts nopen er gespreksmatig en met de nodige tijdreservering op in te gaan.

Tenslotte nog factor 2 en 3 .

Ex is een duidelijke trend ontstaan naar samenwerken sinds het begin van de zeventiger jaren (Ten Cate, 1977). Het is heel gebruike11jk dat huisartsen al of niet geformaliseerd samenwerken met het Maatschappelijk Werk, de Wijkverpleging, dietisten enzovoorts. Dit heeft langzamerhand zo veel invloed gekregen, dat we mogen aannemen, dat samenwerking een formeel doel is geworden in het werk van de huisarts. De weerklank van het methodisch werken heeft dat hier en daar soms nog versterkt (Crebolder, 1977).

De nascholing en het inwinnen van noodzakelijke gegevens 
voor de patiëntenzorg is een reële dimensie. Uit ons onderzoek en ook ult dat van Van Deen (1952) bijwoorbeeld blijkt dat de huisartsen tussen hun werk door tijd aan nascholingsactiviteiten besteden. Dat varlëert van het tussen de bedrijven door lezen van een tijdschrift of pharaceutische reclame tot het bijwonen van klinische demonstraties in het ziekenhuis. Uit mijn meetresultaten is te berekenen dat dat gemiddeld 50 minuten per hulsarts per week is. Ook Van Kooy (1982) toont aan dat nascholing een activiteit is waar de huisarts structureel in zijn werk een plaats voor heeft ingeruind.

Getoetst aan zowel interne als externe citeria lijken de zes factoren de taak-dimensies achter de dagelijkse activiteiten van de huisarts juist weer te geven.

De zes factoren duiden de doelen aan dle de huisarts in zijn praktijkuitoefening tracht te berelken. Als zodanig zou men de factoren de langs empirisch-statistische weg gevonden taken van de huisarts mogen noemen. Aangezien de steekproef van huisartsen, die geobserveerd is, representatief gebleken 1 s voor de populatie van zelfstandig gevestigde huisartsen in Nederland (zie 4.7.3.) verwijzen de factoren naar de taakgerichtheld van de huisartsgeneeskunde in Nederland.

De gevonden taakstructuur geeft bovendien een indicatie voor een aantal kenmerken van huisartsgedrag. Die kenmerken zijn als volgt te omschrijven:

1. Wanneer een meer dan gemiddelde hoeveelheid relatieve tijd besteed wordt aan somatische curatieve zorg dan kenmerkt het gedrag van de huisarts $z$ ich in veel gevallen door het felt, dat er relatief weinig of geen tijd besteed kan worden an taken als verloskundige zorg, zulgelingen- en kleutercontrôles op consultatlebureaus, hulsartsopleiderschap en voor pauzes en persoonlijke bezigheden tijdens het werk.

2. Indien veel wordt samengewerkt met en verwezen naar andere disciplines in de eerstelifns gezondheldszorg gaat dat vaak samen met het geven van onderwijs (huisartsopleiderschap) en een "modernist1sche" prakt1jkvoering, In de zin, dat er relatief weinlg huisbezoeken worden afgelegd.

3. Wordt er relatief veel tijd besteed aan nascholing en 
het plegen van consultatie en inwinnen van inlichtingen ten behoeve van de directe patientenzorg dan is de kans groot dat de hulsarts relatief meer $t$ ljd besteedt aan het bezoeken van zijn patiênten in het ziekenhuis of aan andere vormen van "sociaal contact" met zijn patiènten.

4. Indien ex relatief welnig patiënten worden verwezen naar speclalisten dan is de kans groot dat relatief meer tijd besteed wordt aan survelllance van risicopatiënten en begeleiding van chronisch zieken.

5. Indien er rellatlef meer preventie verleend wordt aan vrouwen in de fertiele leeftijd en aan jonge kinderen, dan is de kans groot dat er relatief minder tijd be steed wordt aan samenwerking met andere disciplines in het eerste echelon.

6. Indien er relatief veel tijd besteed wordt aan gespreksvoering en gespreksmatige behandeling is de kans groot dat er weinig tijd overblijft voor pauzes en persoonl1jke bezigheden. De arts kan dan dus vaker onder een grotere tijdsdruk $z i j n$ werk moeten verricht en.

6.4. De vergelijking tussen de zes factoren en het BasisTakenpakket.

De Landelijke Hulsartsen Vereniging geeft in het "BasisTakenpakket" (LHV, 1983) de taken van de huisarts in vier hoofdcategorieẻn weer

I. Taken, afgeleld van het hulpverleningsproces.

Hiertoe behoren:

1 Entree taken: betreffen vooral de opstelling en attitude als hulsarts ten aanzien van het open staan voor alle vragen van hulp.

2. D1agnostische taken:

- vraagverheldering

- opstellen van werkhypothesen

3 Taken ten aanzien van het behandelingsplan

- afwijzen van de hulpvraag

- afwachten

- zelfzorg adviseren

- voorlichting en adviezen

- medicamenteuze therapie 
4. Terugkoppelingstaken:

- verrichten van ingrepen

- gesprek

- consultatle en verwijzing

- begeleiding

- een soort zelfevaluatie

II. Taken, afgeleid van bepaalde categorieën van patiënten:

- zwangeren en pasgeborenen

- zuigelingen, kleuters en jeudigen

- beroepsbevolking

- be jaarden

- stervenden

- rouwenden

- chronisch zieken

- patiënten die eerste hulp behoeven

III. Ondersteunende taken:

- bevorderen en onderhouden van de vakbekwaamheid

- samenwerking

- soclale kaart: voorlichten over hulpverleningsmoge1ijkheden in de regio

- coördinatie

- praktijkuitrusting

- praktijkorganisatie

- medisch en flnanciële administratie

IV. Overige taken:

- taken vanwege de overheid of anderzins

- signaleren van gezondheidsbeinvloedende factoren

- taken ten aanzien van de beroepsgroep en organisatie van de gezondheidszorg

- taken ten aanzien van de opleiding ten behoeve van de gezondheidszorg

Qua indeling gaat de vergelijking met de door mij gevonden taakstructuur nilet op. "Mijn" structuur omvat:

- somatisch, curatieve zorg

- psychosociaal, curatlef begeleidende zorg

- survellierende, begeleldende zorg voor rislcopatiënten en chronisch zieken

- een somatisch preventieve zorg ten aanzien van geboorteregeling en zuigelingen en kleuters

en twee ondersteunende taken: 
- samenwerking en onderwijs

- nascholling

Het merendeel van de in het LHV-rapport genoemde taakcategorleän blijkt in werkelijkheld wel deel uit te maken van de empirisch gevonden taakstructuur van de huisarts. Een klein aantal categorieen blijkt daar echter geen aanwijsbare plaats in te vinden. Dat heeft verschillende oorzaken. Eensdeels omdat enkele taken slechts incidenteel worden verricht en dus in een transversale observatie ondervertegenwoordigd raken. Als zodanig zijn bijvoorbeeld te noemen "taken vanwege de overheid", zoals het opmaken van overlifdensverklaringen, het aanmelden van besmettelifke zlekten. ledere hulsarts zal zo nu en dan dit soort activiteiten moeten verrichten.

Voor een ander deel worden er in het "Basis-Takenpakket" zaken genoemd, die de meeste hulsartsen in werkelijkheid weinig of niet blijken te doen. Hlervan kunnen genoemd worden de "werkadviezen" (Soeters, 1983) en "voorlichting en adviezen" (Bergsma, 1984).

Er is nog een ander belangrijk verschil tussen de door mij gevonden taakstructuur en het "Bas1s-Takenpakket". Het "Basis-Takenpakket" heeft een duidelijke normstellende strekking. Het schrijft voor wat de huisarts al of niet moet doen en hoe hif dat moet verrichten.

Ik heb alleen een kwantitatleve analyse van het werk van de hulsarts gedaan zonder enige kwaliteitsaspect en zonder gelljktijdige meting van klachten- of probleemaanbod of morbiditeit en kunnen in kwalitatief of normatief opzicht geen uitspraken doen.

Samenvattend heeft de factoranalyse zes goed benoembare factoren of taakdimensies uit de activiteiten van huisartsen opgeleverd, die een acceptabele practische betekenis hebben. Daarmee samenhangend blijken indicaties te bestaan voor een zestal kenmerken van hulsartsgedrag.

De taakstructuur van het "Basis-Takenpakket" komt niet overeen met die, welke door mij is gevonden, mar het merendeel van de taakcategorleën uit het "Basis-Takenpakket" makt wel deel uit van de feltelijke taken van de huisarts. 
Hoofdstuk 7. De regressle-analyse.

\subsection{Inleiding}

In hoofdstuk 6 is door middel van factoranalyse een reductle verkregen van de 41 per hulsarts geobserveerde tijdsvariabelen tot een aantal van zes factoren. Door aan deze factoranalyse nu een ordenende functie toe te kennen, die moet dienen voor verdere analyse, komen we thans toe aan het verklarende deel van het onderzoek. (Van der Zee, 1979).

De vraag, die thans aan de orde is, luldt:

In hoeverre hangen bepaalde kenmerken van:

- de situatie, waarin de huisarts $z i j n$ werk verricht,

- zijn werkwijze, en

- zijn persoon

samen met de variantie in de taakvervulling?

Dit is onderzocht met een enkelvoudige regressieanalyse, dat wil zeggen, dat elk van de onafhankelijke variabelen na elkaar en met constant houden van de overige in regressie is gebracht met elk van de gevonden taak-dimensies, kortweg de "nleuwe" variabelen. In paragraaf $7.2 \mathrm{zal}$ eerst worden besproken hoe $1 \mathrm{k}$ tot "nleuwe" varlabelen gekomen ben en hoe de regressieanalyse is toegepast. In 7.3 volgen dan de resultaten, die vervolgens worden besproken in 7.4 .

7.2. De regressie-analyse.

De zes factoren vervangen de oorspronkelifke 41 tijdsvarlabelen. Iedere huisarts had zijn eigen score op elk van die 41 varlabelen. Ook deze scores kunnen vervangen worden door scores op de zes factoren. Factorscores zljn dus de scores van leder van de hulsartsen op leder van de zes factoren. Die factorscores laten door hun getalsmatige waarde zien welke betekenis een bepaalde factor in de taakultoefening van een bepaalde huisarts heeft. Die scores zijn gestandaardiseerd (Nie et al., 1975), zodat het gemiddelde van die scores steeds 0 bedraagt en de standaarddeviatie 1 . (Voor de frequentie van de factorscores, zle bijlage 4). De oorspronkelijke 41 tijdsvariabelen zijn daarmee nu vervangen door zes "nieuwe" variabelen, genoemd varlabele 1 tot en met variabele 6 , die onderling geen samenhang met elkaar mogen vertonen (zie biflage 5). De inhoud van de va- 
riabelen 18 1dentlek aan die van de factoren.

Er 1s gebruik gemaakt van een gewone, enkelvoudige regressleanalyse (Kerlinger en Padhazur, 1973) volgens de SPSSstandaard programmaturur (Wie et al., 1975).

Regressle-analyse is bedoeld on te berekenen of er een signiflcante samenhang bestaat tussen de afhankelijke en de onafhankelijke varlabelen en zo ja in welke richting en met welke sterkte dat verband wijst. Dat wil zeggen in welke zIn en hoe sterk verandert de afhankelijke varfabele mee, indLen de waarde van én van de onafhankelijke variabelen verandert, bif constant houden van de overige onafhankelijke varlabelen. Daarbij moeten we wel beseffen, dat we met onze meting slechts ten dele de werkel1jk aanwezige va riantie in de te verklaren (afhankelijke) variabelen hebben kunnen reglstreren. Een deel van de in het verzamelde materiaal aanwezige varlantle moet toegeschreven worden aan toeval en meetfouten. Ons onderzoek is nu eenmal een momentopname. Hoewel we sterke aanwijzingen hebben, dat de observaties een redelijk beeld geven van een werkweek van huisartsen, blijft het toch maar een week. De ene week is ntet gelijk aan de andere. Sommlge relevante invloeden hebben we nfet kunnen meten zoals bijvoorbeeld de invloed van het selzoen.

De onafhankelljke variabelen zullen daarom in bescheiden mate de varlantie in de zes varlabelen kunnen verklaren. Bij de regressie-analyse wordt a priori uitgegaan van de nulhypothese; dus van de veronderstelling dat eventuele samenhang tussen de afhankelijke en de onafhankelijke variabelen op toeval berust, tenzij op statistische gronden er aanwijzingen $\mathbf{z} 1 \mathrm{jn}$ om de nulhypothese te verwerpen. Die statistische gronden worden ontleend aan de warde van de F-ratio per onafhankelijk varlabele (Kerlinger en Padhazur, 1973). Dit gebeurt met een signiflcantietest voor elk van de regresste-coëflctënten ( $\beta$ ), volgens de gestandaardiseerde regressle methode, waarbij elke onafhankelifke varlabele wotdt behandeld alsof hif in een aparte stap aan de regressle-vergelijking is toegevoegd, nadat de andere onafhankel1jke varlabelen reeds in dle vergelifking zijn ingebracht. Is de F-ratio gelljk aan of groter dan een bepaalde grenswarde bij een gegeven aantal vrifheldsgraden dan is door middel van de daarbif behorende regressie-coëfficlènt de onathankelijk varlabele op een bepald significantieniveau gebonden aan de afhanke11jke varlabele. 
7.3. De resultaten van de regressie-analyse.

7.3.1. Varlabele 1: de curatieve zorg.

De resultaten van de factoranalyse staan in tabel 7.1 . en leiden tot de volgende conclusie.

Tabel 7.1. Verklaring van de variantie van variabele 1.

r $\quad$ B var.

werksituatie:

prakt 1 jkvorm

praktijkgrootte

$-.07-.03$

ziekefondsratio

$.14-.01$

ratio kinderen $<14 \mathrm{jr}$.

$.09 \quad .02$

gem.aantal pat./uur

$-.13$

.09

$.63 \quad .55 *$

$37 \cdot 6$

werkwijze:

prop.1ab.ond.

prop.verwijzingen

instrumentarium

consult-visite ratio

$\begin{array}{rcr}.34 & .25^{*} & 5.7 \\ .05 & .03 & \\ -.02 & -.06 & \\ .41 & .09 & \end{array}$

arts :

ervaring als huisarts

$\begin{array}{ll}-.14 & -.10\end{array}$

taakbreedte

$-.10 \quad-.02$

diagn.en ther. niveau

$-.16 \quad-.03$

tijd/voorzieningen

$-.31-.15$

samenwerking

$-.10 \quad-.06$

Totaal verklaarde varlantie: $53 \%$

(Een B* heeft een F-ratio, die significant is op het $5 \%$-niveau).

Alle predictoren tesamen verklaren $53 \%$ van de varlantile in variabele 1. Dat is hoog. Twee predictoren vertonen een significante samenhang. Dat is in de eerste plaats het "gemiddeld aantal patiënten per uur" en in de tweede plaats de "proportie aangevraagd laboratoriumonderzoek".

Het "gemlddeld aantal patiënten per uur" heeft de sterkste samenhang. Naarmate er zich meer patiënten bif de hulsarts komen is de kans groter dat er meer tijd aan somatisch- 
curatieve zorg besteed wordt. We laten hierbif in het midden warom ex meer patiënten bij de hulsarts komen. Ener$z 1 j d s$ kunnen er momenten $z 1 j n$, dat meer patiënten op eigen initiatlef hun hulsarts bezoeken, anderzijds komt het voor dat hulsartsen soms sterk de neiglng hebben somige patienten herhaaldelijk terug te bestellen (Bergsma, 1984). Een groter proportle aangevraagd laboratorlumonderzoek hangt eveneens, $z i j$ het in mindere mate, slgnificant samen met de tifd die besteed wordt aan curatieve zorg. Dit benadrukt, dat huisartsen merendeels in hun patiëntencontacten curatieve zorg verlenen. D1t is in overeenstemming met de bevindingen van Blokland-Kuhler (1974) en Bremer en Van Westreenen (1964). Het maakt daarbij kennelijk geen verschil of het zilekenfonds- of particulier-verzekerde patiènten betreft, want de zlekenfondsratio hangt niet signiflcant samen met de tijdsbesteding aan curatieve zorg. 
7.3.2. Varlabele 2. Het samenwerken met en verwijzen naar andere disciplines in het eerste echelon en het geven van onderwijs.

Tabel 7.2. De verklaring van de varlantie in varlabele 2 .

\begin{tabular}{lrrr}
\hline & $r$ & $\beta$ & \%var. \\
\hline werksituatie: & & & \\
praktijkvorm & .20 & .10 & \\
praktijkgrootte &. .02 & -.10 & \\
ziekenfondsratio & .02 & .07 & \\
ratio kinderen 14 jr. & .01 & .10 & \\
gem. aantal pat./uur & -.14 & $-.28 *$ & 2.1 \\
& & & \\
werkwijze: & .20 & $.27 *$ & 6.0 \\
prop.lab.ond. & .12 & .08 & \\
prop.verwijzingen & -.01 & -.01 & \\
instrumentarium & .27 & $.41 *$ & 11.7 \\
consult-visite ratio & & & \\
& & & \\
arts: & -.07 & -.10 & \\
ervaring als huisarts & .00 & .03 & \\
takbreedte & .00 & -.07 & \\
diagn.en ther. niveau & .02 & .05 & \\
tijd/voorzieningen & .21 & $.25 *$ & 2.3 \\
samenwerking & &
\end{tabular}

Totaal verklaarde variantle $28 \%$

(Een $B^{*}$ heeft een F-rat1o, die significant is op het $5 \%$-niveau)

Het blijkt dat $28 \%$ van de varlantie door de veertien predictoren wordt verklaard. Dat is een redelljk percentage. De consult-visite ratio blifkt de grootste hoeveelheid variantie te bilnden. Wanneer er relatief meer patiënten op het spreekuur worden geholpen, dan aan huis bezocht, gaat dat gepaard met meer verwijzingen naar eerstelijns disciplines en met een uitgebreidere samenwerking met die disciplines.

De "bereidheid tot samenwerking" speelt een geringere rol. Een kleiner gemiddeld aantal patiënten per uur hangt, weliswaar in niet zo'n sterke mate, samen met een grotere 
tijdgbesteding aan deze variabele, evenals het aantal aangevraagde laboratoriumonderzoeken per 100 patiënt-contacten. Het zou kunnen $z 1 j n$, dat op het spreekuur de voorwaarden gunstig $z i j n$ om dieper op de achterliggende problematlek in te gaan en zo nodig de patient voor verdere hulp door te verwijzen naar andere hulpverlenende instanties. Uit onderzoek van Bergsma (1984), Gerritsma en Smal (1982) blijkt, dat de hulsarts met de patient moet praten om hem naar 1nstanties bulten de gezondheldszorg te verwijzen. Voor dit soort gesprekken lijkt men met de patiënt bij voorkeur een afspraak te maken. Bij de interpretatie van varlabele 2 in hoofdstuk 6 , paragraaf 2 is op grond van de sterk negatieve lading van de categorle "reistijd" geconcludeerd dat het overwegend op het spreekuur bestellen van patiënten op een zekere "modernistische" stij1 van prakt1jkvoeren wijst. 
7.3.3. Variabele 3: Het inwinnen van inlichtingen en advies voor de patientenzorg en nascholing.

De verklaring van de variantie van variabele 3 is weergegeven in tabel 7.3 .

Tabel 7.3. Verklaring van de variantie in variabele 3.

$\mathbf{r}$

B \%var.

werksituatie:

ziekenhuis in gemeente

praktijkvorm

prakt 1 jkgrootte

zlekenfondsratio

ratio kinderen $<14 \mathrm{jr}$.

gem.aantal pat./uur

$.25 \quad-.06$

$-.22 \quad-.12$

$-.00 \quad .09$

$-.04 \quad-.09$

$-.42-.45 *$

11.0

$.00 \quad .02$

werkwijze:

prop.uitbest - $1 \mathrm{ab}$.ond.

.22

.13

prop.verwijzingen

.20

.11

inst rumentarium

$-.14$

$-.11$

consult-visite ratio

$-.01$

$-.12$

arts:

ervaring als huisarts

.10

.04

taakbreedte

.16

.18

diagn.en ther. niveau

tijd/voorzieningen

$-.06$

$-.01$

.11

.04

samenwerking

.11

.04

Totaal verklaarde varlantie: $30 \%$

(Een $B^{*}$ heeft een F-ratio, die signifcant 1 s op het $5 \%$-niveau).

Tesamen verklaren de onafhankel1jke varlabelen $30 \%$ van de totale variantle. Er is slechts eén significante samenhang, namelijk met de leeftifdsopbouw in de gemeente van vestiging. Naarmate de proportie kinderen onder de 14 jaar in de bevolking kleiner is, of wat daar nagenoeg gelijk aan is ( $r=-.77, \mathrm{p}<.01$ ) het percentage ouderen in de bevolking toeneemt, neemt de relatieve tijdsbesteding aan deze varia- 
belle toe.

Het morbiditeitspatroon blj ouderen is complexer, er is meer sprake van mult1-pathologie (W11lemse, 1981; Brouwer, 1983; Ollemans, 1975; Schreuder, 1973). Het is daarom begrijpelijk, dat deze situatieve factor zo'n sterke samenhang vertoont. Ik stel mij hierbij voor, dat indien de omstand Igheden dat verlangen, de huisarts niet alleen de dan noodzakel1jke gegeven over de patiënt en zifn klachten verzamelt, maar er ook voor zorgt over de nodige deskundigheld te beschikken voor het verlenen van adequate hulp. 
7.3.4. Varlabele 4. De bewaking van rislcopatiënten en chronisch zieken.

Variabele 4 verwijst naar de secundaire preventleve zorg van de hulsarts. De samenhang met de onafhankelijke variabelen is weergegeven in tabel 7.4.

Tabe1 7.4. Verklaring van de variantie in varlabele 4.

r B \%var.

werksituatie:

praktijkvorm

praktijkgrootte

$-.08-.10$

zlekenfondsratio

ratio kinderen $<14 \mathrm{jr}$.

$-.05 \quad-.15$

$-.16 \quad-.06$

gem.aantal pat./uur

$.16 \quad .17$

$-.04 \quad-.05$

werkwijze:

prop.uitbest. lab.ond.

prop.verwijzingen

instrumentarium

consult-visite ratio

$\begin{array}{rll}.07 & .15 & \\ -.41 & -.30 * & 9.8 \\ .18 & .24^{*} & 6.5 \\ -.09 & .04 & \end{array}$

arts :

ervaring als huisarts

taakbreedte

.23

$.28 *$

5.0

diagn. en ther.niveau

tijd/voorzieningen

.02

.06

$.07 \quad .03$

samenwerking

$.07 \quad-.04$

$-.22-.13$

Totaal verklaarde variantie: $32 \%$

(Een $B^{*}$ heeft een F-ratio, die significant is op het $5 \%$-niveau).

De gegevens geven aanleiding tot de volgende conclusies. $32 \%$ van de totale variantie wordt gebonden door de veertien predictoren. De rubriek werkwijze-varlabelen bindt de meeste varlantie; de proportie verwijzingen blifkt het belangrijkst te zijn. Het relatief minder verwijzen van patiënten naar specialisten gat samen met een relatief grotere tijdsbesteding aan surveillance. Er is een significante samenhang met de uitgebreidheid van het instrumentarium. De 
aard van die samenhang is voorshands niet duldelijk omdat de aard van de relatle nlet ut de regressie-analyse volgt. Hangt het hebben van een uitgebreider instrumentarium samen net survelllance of schaffen hulsartsen, die meer survelllance verlenen een uitgebreider instrumentarium aan? Duidelijke aanknoplngspunten $z \mathbb{1} j \mathrm{n}$ blj anderen niet te vinden. Raupp (1971) beschrijft wel twee typen huisartsen, die veel van instrumentarlum gebrulk maken. In de factoranalyse, die hij verrichtte op de persoons-, praktijk- en werkwijzegegevens, is een factor aanwezlg, die verwijst naar de moderne opvattingen ten aanzlen van de begelelding van patiënten; het geeft weer in welke mate de huisarts recente inzichten ten aanzien van het medisch handelen in praktijk brengt. Op deze factor laadt het gebruik van diagnostisch instrumentarium hoog. Dit gegeven zou er op kunnen wijzen, dat huisartsen, die gemiddeld meer tijd aan survelllance besteden, onder andere daarvoor een uitgebreider instrumentarium aanschaffen.

Van de persoonsgebonden varlabelen levert het aantal jaren, dat men als huisarts werkzaam is een signiflcante bijdrage In de verklaarde variantle. Blj een groter aantal praktijkjaren wordt relatief meer $t i j d$ aan surveillance besteed. Ik veronderstel, dat men dit verband als volgt zou kunnen interpreteren. Naarmate een hulsarts langer in een praktijk gevestigd is, kent hij zijn patiënten langer en beter. Hij kan daardoor ook beter op de hoogte $z 1 j \mathrm{j}$ van de bij de patiënt of diens gezin of famille aanwezige risico's voor bepaalde verstoringen in de gezondheld. Die kennis ten aanzien van levensloop en familialre risicofactoren biedt deze hulsarts juist de mogelijkheld meer survelllerende en anticlperende zorg aan zijn patiënten te geven. 
7.3.5. Variabele 5. De begeleiding van vrouwen in de fertiele leeftijd en van zuigelingen en kleuters.

Met varlabele 5 komen we aan de tweede component van de preventie-activiteiten van de hulsarts, namelijk de begeleiding van vrouwen in de fertiele leeftijd en van jonge kinderen. Dit omvat voornamelijk de pilcontrôles en de zulgelingen- en kleuterzorg. De resultaten van de regressle-analyse staan vermeld in tabel 7.5 .

Tabel 7.5. Verklaring van de variantie in varlabele 5 .

$r \quad \beta \quad$ \%var.

werksituatie:

praktijkvorm

praktijkgrootte

ziekenfondsratio

ratio kinderen $<14 \mathrm{jr}$.

gem.aantal pat./uur

$-.10$

$-.07$

.10

.15

.10

werkwijze:

prop.uitbest . lab. ond.

prop verwijzingen

instrumentarium

consult-visite ratio
$.02 \quad .04$

$-.05 \quad .07$

$-.01 \quad .13$

$.22 \quad .31 * \quad 6.4$

arts :

ervaring als hulsarts

$.00 \quad .12$

taakbreed te

dlagn. en ther.niveau

$-.11$

$-.16$

$-.01$

.12

$t 1 j d /$ voorzieningen

$-.01$

.09

samenwerking

$-.17$

$-.16$

Totaal verklaarde varlantie $24 \%$

(Een $\beta^{*}$ heeft een F-ratio, die significant is op het $5 \%$-niveau).

Deze gegevens geven aanleiding tot de volgende conclusies: De predictoren binden $24 \%$ van de totaal gemeten varlantie. De rubriek situatieve variabelen levert twee significant gebonden variabelen. In de eerste plaats 1 s dat de proportie kinderen onder de 14 jaar in de bevolking. Dat zal nie- 
mand verbazen. Hoe groter de proportle kinderen hoe meer zulgelingen- en kleutercontroles er gedaan moeten worden. In de tweede plaats blijkt, dat narmate de praktijkgrootte toeneemt de relatieve tijdsbesteding aan factor 5 afneemt. We veronderstellen, dat dat betrekking heeft op de zuigelingen- en kleuterzorg. Die wordt door hulsartsen meestal als nevenfunctie uitgeoefend op de consultatlebureaus van de Krulsverenigingen. Naarmate de praktijk groter is, zal de hulsarts de tijd ontbreken on dat werk erbij te doen.

Van de werkwijzevariabelen draagt alleen de consult-visite ratio significant bij aan de verklaring van de variantie. Deze vorm van preventleve begeleiding wordt vooral op het spreekuur beoefend. Het is gebruikelijk dat patiënten voor dit soort zaken naar hun arts toegaan. 
7.3.6. Varlabele 6. De gespreksvoering.

De resultaten van de regressie-analyse $z 1 j n$ weergegeven in de volgende tabel.

Tabe1 7.6. Verklaring van de variantie in variabele 6 .

r $B \quad$ \%var.

werksituatie:

praktijkvorm

praktijkgroot te

ziekenfondsratio

ratio kinderen < $14 \mathrm{jr}$.

.20

$-.06$

$-.17$

$-.18$

$-.02$

$.25^{*}$

.14

$-.23^{*}$

$-.25 *$

gem.aantal pat./uur

werkwijze:

prop.lab.ond.

prop.verwijzingen

instrumentarium

consult-visite ratio

\section{arts :}

ervaring als huisarts

taakbreedte

diagn. en ther.niveau

tijd/voorzieningen

samenwerking

$\begin{array}{ll}.01 & -.06 \\ .02 & -.05 \\ .02 & -.13 \\ .02 & -.04\end{array}$

$\begin{array}{rrr}-.06 & -.12 & \\ .17 & .24 * & 4.7 \\ .01 & -.02 & \\ -.05 & -.02 & \\ .09 & .02 & \end{array}$

Total verklaarde variantie: $19 \%$

(Een $\beta^{*}$ heeft een F-ratio, die significant is op het $5 \%$ niveau).

Deze gegevens laten zlen, dat de onafhankelljke varlabelen slechts $19 \%$ van de varlantle binden. Er zijn dus buiten de onafhankelijke variabelen nog vele andere factoren in het spel, die aan die variantle bijdragen. De prakt1jkvorm en de opvatting over de taakbreedte blijken ongeveer de helft van het percentage verklaarde variantie voor hun rekening te nemen. Een non-solistische praktijkvorm en een bredere taakopvatting hangen significant samen met een relatief grotere tijdsbesteding aan gespreksvoering. De negatieve samenhang tussen de ziekenfondsrat 10 en de ra- 
t1o kinderen onder de 14 jaar in de bevolking met de gespreksvoering kan men mijns inziens niet los van elkaar zien. Betde varlabelen hangen samen met de urbanisatiegraad. In grote steden en in forensische gebleden treffen we 1 n het algemeen relatief meer oudere mensen aan of mensen met een hoger opleldingsniveau, die particuller verzekerd zijn. Deze mensen zullen aan hun hulsarts veel meer toellchting en uitleg vragen. Daarmee wordt ten dele het verband met gespreksvoering duldelijk.

Tenslotte valt op, dat de taakopvating c.q. taakbreedte hiler voor de eerste en enige maal in de regressie-analyse een signiflcante correlatie laat zien. Het betreft hier een taak, die, als er significant meer tijd aan besteed wordt dan gebruikelijk, als een "alternatieve" taak te kenschetsen zou zijn, er van uitgaande dat men de medicamenteuze interventie als traditioneel beschouwd. Ik stel mij voor dat dit niet-traditionele gedrag door die bepaalde taakopvatting mede tot stand komt. Deze taakopvatting of attitude zou dan één van de drijvende krachten zijn voor dat gedrag.

7.4. Bespreking van de resultaten van de regressieanalyse.

Overzlen we nog eens het geheel, dan blijken alle drie de groepen van predictoren in meerdere of mindere mate significant bij te dragen aan de verklaring van de variantie in de zes variabelen. De percentages total verklaarde variantie per variabele zifn ulteraard wisselend, maar over het algemeen redelljk van grootte. Blj de variabele gespreksvoering binden de predictoren de minste variantie.

Alle predictoren dragen signifcant bij aan de verklaring van de variantie van een of meerdere variabelen behalve het gewenste niveau van diagnostlek en theraple en de mening over voldoende tijd en ondersteunende voorzieningen te beschikken.

Er blifven dus 12 predictoren over. Door ledere significante bijdrage van de onafhankelijke variabelen aan de verklaring van de variantie per varlabele uit te drukken in een percentage van de per variabele totaal verklaarde variantie is het mogelijk de predictoren te rangschikken naar de relatleve grootte van hun bijdrage.

Die rangorde ziet er als volgt uit: 
1. De demograflsche opbouw van de bevolking in de praktijkgemeen te.

2. Het gemiddeld aantal patiënten per uur.

3. De consult-visite ratio.

4. Het aantal aanvragen voor laboratoriumonderzoek per 100 patiënt-contacten.

5. Het aantal verwijzingen per 100 patiènt-contacten.

6. De opvatting over de breedte van de taken van de huisarts.

7. De praktijkvorm.

8. De uitgebreldheid van het instrumentarium.

9. Het aantal jaren, dat men als huisarts is gevestigd.

10. De praktijkgrootte.

11. De ziekenfondsratio.

12. De bereidheid tot samenwerking met andere hulpverleners.

Het blijkt, dat de eerste acht predictoren ult de bovenstaande 11 jst $87,4 \%$ van de totaal verklaarde varlantie in de zes factoren binden. De resterende vier leveren zo'n geringe bijdrage, dat ze nagenoeg verwaarloosbaar zijn.

Dit resultaat geeft een inzicht welke van de hier gebruikte onafhankelijke variabelen in belangrijke mate samenhangen met de "nleuwe" varlabelen. In tabel 7.7. 1s dit nog eens overzichtelijk weergegeven. 
Tabe1 7.7. Overzicht van de "significante" bijdragen aan de per variabele totaal verklaarde varlantie (uitgedrukt in percentages van de totaal verklaarde variantie per variabele).

\begin{tabular}{|c|c|c|c|c|c|c|c|}
\hline & & $\begin{array}{l}\text { cur. } \\
\text { zorg }\end{array}$ & $\begin{array}{l}\text { sam. } \\
\text { on- } \\
\text { derw. }\end{array}$ & $\begin{array}{l}\text { cons. } \\
\text { nasch. }\end{array}$ & $\begin{array}{l}\text { sec. } \\
\text { prev. }\end{array}$ & $\begin{array}{l}\text { prim. } \\
\text { prev. }\end{array}$ & $\begin{array}{l}\text { gespr. } \\
\text { voe- } \\
\text { ring }\end{array}$ \\
\hline \multicolumn{8}{|c|}{$\begin{array}{l}\text { 1. } \quad \text { ratio } \\
\text { kinderen }\end{array}$} \\
\hline 2 . & $\begin{array}{l}<14 \mathrm{jr} . \\
\text { gem.aant. }\end{array}$ & - & - & 36,7 & - & 19,2 & 26,3 \\
\hline & $\begin{array}{l}\text { pat./uur } \\
\text { consult- } \\
\text { visite }\end{array}$ & 70,9 & 7,5 & - & - & - & - \\
\hline 4. & $\begin{array}{l}\text { ratio } \\
\text { prop.lab. }\end{array}$ & - & 41,8 & - & - & 26,7 & - \\
\hline 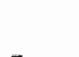 & ond. & 10,8 & 21,4 & - & - & - & - \\
\hline $\begin{array}{l}5 . \\
6 .\end{array}$ & $\begin{array}{l}\text { pro.verw. } \\
\text { taak- }\end{array}$ & - & - & - & 30,6 & - & - \\
\hline & $\begin{array}{l}\text { breedte } \\
\text { prakt } 1 j k-\end{array}$ & - & - & - & - & - & 24,7 \\
\hline & $\begin{array}{l}\text { vorm } \\
\text { uitgebr. }\end{array}$ & - & - & - & - & - & 23,7 \\
\hline & $\begin{array}{l}\text { instrum. } \\
\text { prakt } 1 j k-\end{array}$ & - & - & - & 20,3 & - & - \\
\hline 10. & $\begin{array}{l}\text { ervaring } \\
\text { praktijk- }\end{array}$ & - & - & - & 15,6 & - & - \\
\hline 11. & $\begin{array}{l}\text { grootte } \\
\text { zieken- }\end{array}$ & - & - & - & - & 15,4 & - \\
\hline 12. & $\begin{array}{l}\text { fondsratio } \\
\text { samen- }\end{array}$ & - & - & - & - & - & 13,2 \\
\hline & werking & - & 8,2 & - & - & - & - \\
\hline
\end{tabular}

U1t tabel 7.7. blijkt, dat de acht belangrijkste verklarende varlabelen meestal ten aanzien van niet meer dan twee afhankelijke variabelen een signiflcante bijdrage in de verklaring van de variantie leveren en dat die bijdragen qua grootte nogal uiteenlopend zijn.

Regressle-analyse laat het trekken van conclusies ten aanzien van de causalitelt in de gevonden relaties niet toe. 
Uit oogpunt van beleid is het echter van belang te weten of er aanwijzingen voor aangrijpingspunten bestaan on veranderingen in het functioneren teweeg te brengen in een bepaalde gewenste richting. Een algemeen beleldsdoel is het versterken van de eerstelijn. Meer in het bijzonder betekent dat het versterken van de thuiszorg, het beperken van de uitstroom in de intramurale zorg en het bevorderen van preventie.

Het gemiddeld aantal patiënten per uur en de praktijkgrootte blijken nlet of nawwelijks te correleren met verschillen in tijdsbesteding ten aanzien van taken als preventie en gespreksvoering .

Het gemiddeld aantal patiënten per uur verklaart wel in belangrijke mate de verschillen in curatieve zorg.

Deze bevindingen $11 j$ ken geen steun te geven aan het streven naar praktijkverkleining als men daarmee op het oog heeft dat de huisarts dan meer tijd zou gaan besteden aan preventie of gespreksvoering.

Het onderzoek van Bergsma (1984) levert aanwijzingen, dat de lnstroom van patiënten bij de hulsarts niet onafhankelijk gebeurt. Dat wil zeggen, dat er geen sprake is van een input-output situatie, maar dat er beter gesproken zou kunnen worden van een circulair model. Volgens Bergsma bestat ongeveer $60 \%$ van de instroom uit patlënten, die door de arts zijn terugbesteld. Het is zeer de vraag of deze organisatorische gang van zaken door praktijkverkleining zal veranderen.

We1 komt er uit mijn resultaten een aanwijzing naar voren, dat de taakopvatting, de attitude, een drijvende kracht in het gedrag van de huisarts kan zijn. Met name geldt dat voor de minder traditionele, in zekere zin als "alternatief" aan te dulden taak: gespreksvoering. 
Hoofdstuk 8. Samenvatting en besprek1ng van de resultaten. 8.1. Inlelding.

In dit hoofdstuk geven we een terugblik en een beschouwing op een aantal essentielle onderdelen uit dit proefschrift. Achtereenvolgens komen aan de orde:

- de ontwikkeling van het observatie-1nstrument (8.2.);

- de meting van de taakperceptle (8.3.);

- de aard en het karakter van het onderzoek en de beperkingen daarvan $(8.4$.$) ;$

- een bespreking van de resultaten (8.5.).

8.2. Het observatie-instrument.

Tot nog toe is er in ons land betrekkelijk weinig empirisch beschrijuend en taakanalytisch onderzoek gedaan van de hulsartsgeneeskundige gezondheldszorg (Lamberts, 1982). Er kan in deze niet van een onderzoektraditie worden gesproken. De onderzoeken, die gedaan zijn, kenmerken zlch door een grote verscheidenheid in methodologische opzet, benadering en vraagstelling. Dat heeft onvermijdelijk tot gevolg, dat er weinig hypothesevorming is ontstaan en dat de meetinstrumenten zeer verschelden zijn. De onderzoeken vertonen daardoor veelal een ad hoc karakter, dat w11 zeggen ze zijn plaats- en praktijkgebonden. Hierdoor is de generaliseerbaarheld van de bevindingen gering en de resultaten zijn ook moellijk vergelijkbaar.

Ik kon in dit onderzoek nauwel1jks uitgaan van en aanhaken op voorgaand onderzoek met als gevolg, dat met name wat betreft de ontwlkeling en de toepassing van een systeem van observatle-categorleën, dit overwegend gebaseerd is op eigen creativiteit. Dit soort pogen geeft onzekerheid omtrent de warde ervan. In deze rapportage 18 vooral het observatle-instrument belangrijk. Als leldraad bij het ontwerpen van een systeem van observatie-categorleën heb $1 \mathrm{k}$ gebrulk gemaakt van door deskundigen geformuleerde algemene criteria en theoretische ultgangspunten enerzijds en van een schematisch concept over de taken van de hulsarts anderzijds. Dit laatste is ontleend an het LHV-rapport: "De Taken van de Huisarts" (LHV, 1977) en de KNMG-discussienota De Plaats van de Medicus in het Eerste Echelon" (KNMG, 1976). 
Door middel van proefonderzoek werd de inhoudsvaliditeit van het instrument beproefd. Met enige bijstellingen bleek die tenslotte aan het doel te beantwoorden. Alle te observeren activiteiten in de verschillende voorkomende gevallen zijn zodanig gedefiniëerd, dat ze eenduidig onder de gebruikte categorieën konden worden ondergebracht.

Met testmetingen kon een voldoende betrouwbarheld in de observatiemetingen tussen de observatoren onderling en tussen die van de observatoren en van mijzelf worden aangetoond (Boots, 1983). We hebben geen aanwijzingen gekregen, dat de aanwezigheid van de observatoren de actoren noemenswaard in hun doen en laten heeft belnvloed of de gang van zaken in het arts-patiënt contact heeft verstoord, waardoor een belangrijke systematische vertekening in de onderzoeksgegevens zou kunnen zijn opgetreden.

Samengevat kunnen we stellen, dat met het ontwikkelde systeem van observatie categorieën een voor het beoogde doel valide en betrouwbare meting van de feltelijke taakuitoefening van huisartsen is verkregen, dankzij een intensieve training van inhoudsdeskundige observatoren en een viertal testmetingen tijdens de uitvoering van het onderzoek.

\subsection{De taakperceptiemeting.}

Uit de literatuurstudie is naar voren gekomen dat de taakopvatting een van belang zijnde factor kan zijn bij de verklaring van verschillen in de taakultoefening, Daarom is een instrument voor het meten van de taakperceptie ontwikkeld. Hiervoor is een vragenlijst ontworpen, waarin per functie, c.q. taak uitspraken werden opgenomen betreffende hetgeen de huisarts tot $z 1 \mathrm{jn}$ taken behoorde te rekenen. De geldigheid van deze vragenlijst berust op "face-value" en "expert opinion".

Deze vragenlijst is voorgelegd aan de geobserveerde hulsartsen (kleine steekproef) en, om te trachten de betrouwbaarheid van de meting nog te verhogen, aan een grotere steekproef van huisartsen, representatief op de kenmerken: solist/non-solist, urbanisatiegraad van de praktijkgemeente, en prakt1jkgrootte (grote steekproef).

U1t de "grote", gerandomiseerde steekproef werd een respons van $70 \%$ verkregen. Vergelijking van belde steekproeven met de totale huisartsen-populatie leverde geen significante verschillen op ten aanzien van de selectie-criteria. 
U1t de antwoorden van de grote steekproef zijn schalen geconstrueerd ten aanzien van de opvattingen over de breedte van de taken, het niveau en de omstandigheden, waaronder men als huisarts werkzaam was.

8.4. De ard en het karakter van het onderzoek en de beperkingen ervan.

Dit onderzoek is in felte een momentopname. Het representeert een transversale meting in een steekproef van 91 hulsartspraktijken, gestratificeerd op de kenmerken urbanigatlegraad van de gemeente van vestiging, praktijkgrootte en praktijkvorm (solistisch, non-solistisch). Het onderzoek heeft een exploratief, beschrijvend deel en een verklarend dee1. Dit laatste is riskant. Verklarend onderzoek kan beter gebeuren in een longitudinale studie. Dit betekent hier grote voorzichtigheid en terughoudendheid in het trekken van conclusles. De uitkomsten dienen eerder als aanwijzingen te worden beschouwd. Vanwege die momentopname is getracht de observaties zo goed mogelijk over de werkdagen te verspreiden (de weekeinden werden niet geobserveerd) en in een zo juist mogel1jk proportionele verhouding wat betreft de rubrleken: spreekuren, visites en niet-patiënt geboden activitelten. Dit doel werd in voldoende mate berelkt. De observatlegegevens van 93 huisartsen, de ultkomsten van de taak-perceptlemeting van deze zogeheten "klelne" steekproef en van een "grote" steekproef van huisartsen, representatief op de kenmerken solist/non-solist, prakt1jkgrootte en urbanisatiegraad van de gemeente van vestiging hebben als het gemeenschappelijke data-bestand van het onderzoek gedlend voor zowel het onderzoek van Boots (1983) als het ijne. Na de gegevensverzameling en de constructie van de meeteenheden hebben de onderzoekers 1 n de analyse verschl1lende wegen bewandeld naar verschillende doelen. Het onderzoek van Boots betreft een functie-analyse met als doel de plaats, die de hulsarts in de Nederlandse gezondheldszorg inneemt empirisch te beschrijven. De werkzaamheden van de huisarts werden daartoe ingedeeld in zes functies en vier aanvullende rubrieken: "condities" (ondersteunende activiteiten voor de praktifkvoering), "activiteiten als arts", "apotheekwerkzaamheden" en "rest". Deze indeling kwam tot stand aan de hand van het normatieve takenpakket van de hutsarts, beschreven door commissies van (huis-)artsen op 
verschillende momenten in de ontwikkelingen van het huisartsen-beroep en met verschlllende doeleinden. Hij verkreeg daarmee een kwantitatieve bepaling van de rol van de hulsarts in de gezondheldzorg door langs empirische weg te meten hoe qua tijdsbesteding de zes functies en de werkrubrleken zlch onderling verhouden. Met de taakopvatting, de kenmerken van de praktijksituatie en van de gemeente waarin de praktijk gevestigd is werd gezocht nar een verklaring voor de verschillen tussen de afzonderlijke hulsartsen in de aard en de omvang van de onderscheiden functies en rubrleken in hun werk.

Mijn onderzoek heeft tot doel:

a. het opsporen van taakdimensies in de activiteiten die huisartsen dagelijks verrichten;

b. de verschillen per huisarts in de gevonden taakstructuur te verklaren met behulp van kenmerken van de werksituatle, de werkwijze en de persoon van de hulsarts.

\subsection{Bespreking van de resultaten.}

In het kader van de eerste doelstelling werd op de relatieve tijdsbestedingen van de 41 observatle-categorieën (in procenten van de per hulsarts geobserveerde tijd) een factoranalyse uitgevoerd ter toetsing van de voorspelde schematische taakstructuur. De voorspelling kon niet bevestigd worden. $\mathrm{Na}$ herhaling van de factoranalyse werden zes goed benoembare factoren gevonden, die ruim $37 \%$ van de totale varlantle verklaren. De zes factoren verwijzen naar de volgende taakdimensies:

I. Somatisch curatileve zorg.

II. Verwijzen naar en samenwerken met andere disciplines in het eerste echelon en het geven van onderwijs.

III. Inwinnen inlichtingen en advies voor de patientenzorg en nascholing.

IV. Secundiare preventie en begeleiding van ristcopatiënten en chronlsch zleken.

v. Primalre preventle van vrouwen in de fertlele leeftijd en van jonge kinderen.

VI. Gespreksvoering.

Met deze zes factoren laten zich zes gedragskenmerken van huisarts-zijn onderschelden: 
1. De somaticus die zlch veelal richt op diagnostiek en med1sch-technische behandelingen, zeer in beslag genomen wordt door zijn praktijk en daarom geen nevenactiviteiten verricht.

2. De hulsarts, die veel samenwerkt met en verwljst naar andere eerste 11 jns hulpverleners, huisartsoplelder is en een "modernistische" praktijkvoering heeft door zijn patiénten relatief weinig an huis te bezoeken.

3. De hulsarts, die veel tijd besteedt aan nascholing en zijn patiènten in het zlekenhuis opzoekt.

4. De huisarts, dle weinlg verwijst en extra aandacht besteedt aan secundalre preventie en begeleiding van rislco-patiënten en chronisch zleken.

5. De somatisch Ingestelde hulsarts, die veel preventieve zorg verleent aan vrouwen in de fertiele leeftijd en jonge kinderen en weinlg of niet samenwerkt met andere disclplines.

6. De inlnder somatisch-gerichte huisarts, die veel tijd besteedt aan gespreksvoering en die, door de daarmee gepaard gaande verlenging van de consultduur, onder druk moet werken en dus weinig tijd overhoudt voor pauzes en persoonlijke bezigheden.

Vergelijking van de door mij gevonden taakdimensies met die, welke ult andere onderzoeken $z 1 j n$ af te leiden, met name die van Van der Wielen, 1960; Bremer en Van Westreenen, 1964; Oosterhuis, 1972; Bremer, 1978 makt niet de indruk dat er in de loop der jaren grote fundamentele wijzigingen zijn opgetreden. Dok Bremer (1978) kon na een analyse van een willekeurige werkdag in 1973 niet anders concluderen dan dat de taken van de huisarts nog steeds dezelfde waren als hij op grond van door hem in 1964 verricht onderzoek kon vaststellen. De doelstelifngen, c.q. Intenties zijn wel dezelfde, maar de inhoud van het werk was veranderd. Het frappeerde Bremer dat medisch matschappelijke ontwikkelingen (bljvoorbeeld geboorteregeling en anticonceptie) meer Invloed op de taakinhoud hebben dan zuiver medisch-technische. De inhoud van de zorg rondom de voortplanting 18 sterk gewijzigd. In de vijftiger jaren lag de nadruk op de practische verloskunde. Dit is geëvolueerd naar geboorteregellng, adviezen ten aanzien van sterilisatie en dergelijke en nog maar weinig practische verloskunde. Een andere van belang zijnde ontwlkkeling is de opkomst 
van de nascholing, het geven van onderwijs en de samenwerking met de andere disciplines.

Daarentegen bekleedt de huisarts nog steeds evenals vroeger een functie in de zuigelingen- en kleuterzorg. Zowe1 voor eligen patiënten als niet-eigen patiënten.

Daarnaast $z 1 j n$ een aantal zaken kennelijk niet duidelijk tot ontwikkeling gekomen. In dit verband zijn te noemen de survelllance. Op grond van de gemeten relatieve tijdsbestedingen aan deze activiteit is de conclusie, dat het qua omvang geen vooraanstaande plaats inneemt, ondanks alle aansporing van de plettzorgers op dit gebled (Van der Dool, 1970; Van der Feen, 1977).

Hetzelfde is op te merken ten aanzien van gespreksvoering. Ook al is het klachtenaanbod inhoudelijk veranderd in de loop der jaren, de huisarts blijft in het algemeen toch een duidelijke somatisch-geneeskundige gerichtheid ten toon spreiden. In hoeverre dit van invloed is op de kwaliteit of de adequaatheld van de hulpverlening door de huisarts kunnen we met dit onderzoek niet beoordelen.

De taakstructuur, zoals gebruikt in het "Basis-Takenpakket van de Huisarts" (LHV, 1983) is een schematische indeling, die niet overeenkomt met de door mij gevonden structuur. De door mij beschreven dimensies zijn in hun geheel wel terug te vinden in het Basis-Takenpakket. Het Basis-Takenpakket is een normatleve, gedetallleerde en zeer omvangrijke taakomschrijving, waarop "ieder in Nederland praktiserende hulsarts aanspreekbaar 1s" (LHV, 1982). Van een aanta1 taken uit het Basis-Takenpakket, zoals de taken ten aanzien van de beroepsbevolking, met name "werkadviezen" en ten aanzlen van het handelingsplan, in casu "voorlichting en adviezen" is het de vraag in hoeverre die een werkelifke plaats hebben in het handelen van hulsartsen. Onderzoeksgegevens van Soeters (1983) en Bergsma (1984) w1jzen er eerder op, dat dat niet het geval is.

Voor de verklaring van de variantie in de door mijgevonden taken van de huisarts zijn een aantal van de gebrulkte verklarende variabelen belangrijk gebleken. Met name zijn dat:

- het gemlddeld aantal patiënten per uur

- de leeftijdsopbouw in de gemeente war gepraktiseerd wordt

- de consult-visite ratio

- de proportie aangevraagd laboratorlumonderzoek 
Bovendlen 1 s een Interessante relatie gevonden tussen de talk: gespreksvoering en de breedte van de taakopvatting. Hlerblj zou men kunnen veronderstellen dat bij hulsartsen die zich profileren op het gebied van de gespreksvoering, dat mogelijkerwijs doen vanult een bepaalde opvatting $c . q$. grondhouding. Dle attitude zou cén van de drijvende krachten kunnen $z 1 j n$ voor hun gedrag.

Over de betekenis van maatregelen als praktijkverkleining, ultbrelding van diagnostische faciliteiten en samenwerking, als aangrifpingspunten voor verschuivingen in de taakultoefening van hulsartsen in een bepalde gewenste richting, laat dit onderzoek het trekken van conclusies niet toe. Bovendien 18 onze gezondheidszorg een complex systeem met zeer complexe verhoudingen. In $\mathrm{zo}^{\prime} \mathrm{n}$ systeem is het moeilijk om verschulvingen aan te brengen, zeker met maatregelen die op $\epsilon e n$ of een beperkt aantal punten aangrijpen en onvoldoende op elkaar zijn afgestemd. Wat men op het ene punt tracht te veranderen wordt door een aanpassing op een ander punt weer ongedaan gemaakt.

op grond van de onderzoeksresultaten ben ik genelgd te denken, dat men voor verdere ontwikkeling en aanpassing van de hulsartsgeneeskundige zorg zich moet richten op de attitude van de huisarts en het bevorderen van samenwerkingsverbanden om gedragsveranderingen teweeg te brengen. Het gevonden verband tussen taakopvatting en gespreksvoering houdt een aanwijzing in dat de attitude een van de drijvende krachten is voor het gedrag. De zes gevonden gedragskenmerken wijzen er mijn inziens op, dat in sommige gevallen bij huisartsen sprake $\mathbb{1 s}$ van een zekere persoonlijke affinitelt tot delen van het huisartsenwerk, zoals de somatisch-technische zorg, de preventie of de gespreksvoering.

Dit zou kunnen betekenen dat wanneer in samenwerkingsverbanden, bv. groepspraktijken of gezondheidscentra, artsen met die verschillende affiniteiten werkzaam $z i j n, z 1 j$ e1kaar in protoco1-besprekingen of bij intercollegiale toetsing in belangrijke mate kunnen stimuleren, motiveren en aanvullen.

In de nascholing zou onder andere aandacht besteed moeten worden aan attitude-ontwikkeling . onder die condities zouden prakt1jkverkleining, samenwerking, nascholing en toetsing mijns Inzlens wel een gunstig effect op de versterking van de huisartsgeneeskundige zorg kunnen hebben. 
Summary.

This thesis represents the results of a task analysis among 91 Dutch general practitloners. Attempts have been made to explain quantitiative differences in task performance by some characteristics of the working-enviroment, the working-method and the general practitioner.

The commencement of this study is discribed in chapter 1. A global review is given of the rise of family medicine as an occupation in the Netherlands. In the fifties a concurrential crisis took place in family medicine/general practice with regard to the specialised medical care services. The origin of the crisis had to be sought in the radical technological changes in medicine and in morbidity-pattern after World War II. By means of rationalisation and professionalisation this situation could be won.

The early seventies proved to be the beginning of a new era for general practice in the Netherlands. Health care services threatened to be an expensive undertaking. The government began to direct the policy of strengthening the primary health care system. Suddenly new opportunities arose for family medicine/general practice.

In order to show his contribution to the health care services a job-description of the family physician/general practitioner was indispensable for that planning. However there was a lack of empirical data to issue such a job-description. As a result of this deficlency a recourse has been taken to visions speculations and intentions to describe the general practitioners jobdescription. In the issued job-descriptions the broad spectrum philosophy of the "Woudschoten" conference (1959) concerning the general practitioners tasks is fully present.

The necessary empirical substructuring of the set of jobs actuated my dectsion in executing this study. I Intended to search for task dimenstons in the dally activities of general practitioners and to explain the differences in time-spent in taskperformance by means of structural and personal varlables.

In chapter 2 a commentary is given on the literature in relation to the objectives. Most of the important practice-analyses studies in the Netherlands appeared to have been directed elther to parts or special aspects of the general practitioners medical performance. The data concerns only a limited number of pract1ces. These studies give certain indications for a task-structure 
and for those variables correlating with the variance in task performance.

In chapter 3 the design of the observation-instrument has been described. For that design reference is made to the job-description as issued by the National Dutch Association of General Practitioners. The observation categorles have been elaborated in sets of activities as operationalisations of the following tasks: diagnostics therapeutics, referral attendance and prevention. Besides these tasks additional groups of (supporting) activities were ldentifled. In this manner the entire scope of the daily occupational activities of the dutch general practitioner could be covered. It was proved that the observationinstrument had an appropriate validity for the objective in this study. To establ1sh the task perception a questionnalre was presented to the general practitioners. Statements on the following topics were formulated in this questionnalre:

- the scope of task-performance

the level of dlagnostics and therapeutics

the willingness to co-operate with other health workers

the desire avalifility of time and supporting health care facilities.

The design of the study and the manner in which 1 t was executed are described in chapter 4. Behaviour-observations in a select representative sample of 91 general practitioners were conducted by speclally trained medical observers during 20 hours per general practitioner, spread over 4 to 5 days in one week in the period March t111 June 1979. All the activities performed by the general practitloner in those 20 hours were recorded by means of a registration device which made it easily possible to ensure quick processing of all data. The task perception questionnaire was not only presented to the 91 general practitioners in the observation-study, but also to 614 general practitioners forming a representative national sample according to relevant features for this study. In four tests it could be proved that the observations had a sufficlent level of objectivity where the scores of the Individual observers were concerned as well as to the authors testscorses.

The mean time-spent to each of the observed activities are given 1 in chapter 5 as well as the mean scale-scores of the task-perception. It seems that the general practitioners time $1 \mathrm{~s}$ predo- 
minantly occupled by diagnostic and therapeutic activities, traveliing time, registration and practice-management in comparison with prevention and attendance to which only a relatively small amount of time is spent. An average of $10 \%$ of all patients attending the general practitioner is referred to speclalists and to other workers within the health care system. Referral to professional assistance outside the health care system occurs extremely seldom.

A wide range of dispersion in whilch little structure is found turns out to be present in the task-perceptions. The clustered answers out of the questionnaire show conspicious differences with regard to the extent of the width of the task-perception. There is however more unanimity regarding the desired level of diagnostics and therapeutics.

In chapter 6 the results of the factor analysis on the relative time spent on the observation categories is reported. Six factors or task dimensions were found:

- somatic curative care

- co-operation with other disciplines and teaching

- gathering useful information concerning patient care and the post-graduate education

- secundary prevention and survel1lance

primary prevention for women in fertile age and for young children

interactive communication and counseling.

With these six factors indications could be obtained for six behaviour characteristics:

the family doctor who is evindently directed to intercurrent somatic cure and care

the general practitioner who more than averagely cooperates with other health care workers acts as a teacher and performs a modernistic style of exercising

the general practitioner with a more than average timespent on post-graduate education and consultating specialists

the general practitioner with special interest in secundary prevention who refers relatively few patients to speciaists

the general practitioner who is specially directed to primary prevention of women in fertile age-perlod and of young children 
the general practitioner with special interest in interactive communication and counselling.

The task-stucture revealed by me in this study seems to fit into the job-description 1ssued by the national Assoclation of General Practitioners, however that description is much more wide-ranging.

That difference can be attributed to differences in state. My empirical task-structure is in fact the result of a task analysis without simultaneous measurement of quality aspects or problem-supply. The issued job-description has an evident normative tendency. It describes in detall what the doctor has to do in the different conditions that can occur.

In chapter 7 an explanation of the variance in time-spent to the "new" tasks has been sought after. This has been undertaken by a simple regression analysis. It turns out that structural variables have the strongest correlation with the relative time-spent on "somatic curative care", especlally the age features of the population the patient-load the ratio surgery concacts-home visits and the proportion of laboratory investigations. But the patient-load and practice-size hardly correlate with "prevention" and "Interactive communication and counselling". These results give no indication that decreasing practice-size will give rise to a relatively more time-spent on "prevention", "attendance" and "counselling and interactive communication".

In chapter 8 the relevance of the results is discussed. As has been shown by Bergsma (1984) the patient-load is not an independant phenomenon. He found that about $60 \%$ of all people who attended their general practitloner were in one form or another recalled by him. It would be better to speak of a circular model in health care assistence. Perhaps this organisational peculiarity can prohibit the expected effects of decreasing practice-size on the destred shift in time allocation to "prevention" and "attendance". On the contrary I recieved Indications that the attitude, the task-perception, is one of the important driving forces $\mathbb{1 n}$ the behaviour of dutch general practitioners. Therefore, I state that by employing general practitioners with complementary affinities with regard to task performance, such as famlly physiclans with somatic, preventive and communicative affinities in patient care the foundation of group practices 
and health care centres could stimulate the strengthening of primary health care. In these settings protocol discusslons and inter-colleague evaluation could be an important means to achieve that aim. 
Aalderen, H.J. van

Anders helpen, anders helen. Amsterdam, V.U., oratie, 1974.

Aalderen, H.J van; Haan, M. de; Staveren, G., van

Richt11 jnen voor de opleiding tot huisarts. Huisartsen

Instituut Vrije Unfversitelt Amsterdam, 1980.

Aulbers, B.J.M.; oliemans, A.P.

Beschouwlngen over het verrichtingencijfer. Hulsarts en Wetenschap, 14, 423-434, 1971 .

Aulbers, B.J.M.; Ward, F., de

Praktijkanalytische gegevens uit het Intermitterend Morbiditeits Onderzoek, Huisarts en Wetenschap, 13, $171-177,1970$.

Bergsma. J.J.

Het bezoek aan de hulsarts. I. Naar de dokter en terug. Medisch Contact, 39, 683-695, 1984.

Bergsma, J.J.

Het bezoek aan de hulsarts. In de spreekkamer. Medisch Contact, 23, 721-724, 1984.

Bergsman, J.J.; Fleret, G.

Rapport I: "I Spreekuur". Naar de huisarts en terug. Subfaculte1t Psychologie Tilburg, augustus 1980.

Beus, Ch.H., de

Elektrocardiografie in een huisartspraktijk. N1 jmegen, dissertatie, 1969.

Blokland-Kühler, N.M.

Arbeidsstudie in een huisartspraktijk. Huisarts en Wetenschap, $17,256-259,1974$.

Boot, C.P.M.

Rislcofactoren voor coronalre hartzlekten. Screening en interventle in een hulsartspraktijk. Leiden, dissertatie, 1979.

Boots, J.M.J.

Het werk van de huisarts. Maastricht, dissertatie, 1983.

Boots, J.M.J.

Gedragsobservatie reglstrator. Gezondheld en Samenleving, $1,302303,1980$.

Boots, J.M.J.; Zutphen, W.M., van

Taakopvattingen van de hulsarts. Medisch Contact, 36 , $65-68,1981$.

Bouhuifs, P.A.J.

De ontwlkkeling van het Praktisch Medisch Onderwijs in 
de Huisartspraktijk. Maastricht, dissertatie, 1983. Bremer, G.J.

Dokters in hun dagelijkse doen. Hulsarts en Wetenschap, $21,477-483,1978$.

Bremer, G.J.; Westreenen, E., van

De werkzaamheden in de huisartspraktijk nu en in de toekomst. Huisarts en Wetenschap, 7, 2-17, 1964.

Brouwer, W.

Het eenmalig geriatrisch consult. Huisarts en Wetenschap, 26, 140-144, 1983.

Buma, J.T.

De hulsarts en zijn patiënt. Amsterdam, dissertatle, 1949.

Buma, J.T.

Beschouwingen over de plaats van de huisarts in de $\mathrm{Ne}-$ derlandse gezondheidszorg. Nederlands Instituut voor Preventieve Geneeskunde, Leiden, 1959.

Buma, J.T.

Inventarisatie van een hulsartspraktijk. Medisch Contact, 7, 151-155, 1952 .

Cate, R.S., ten

De praktijkuitvoering van de huisarts. Stenfert Kroeze NV, Leiden, 1963.

Cate, R.S., ten

Samen werken, samen bouwen in de eerste 11 jnsgezondheidszorg. Bohn, Scheltema en Holkema, Utrecht, 1977. Cohen, J.

Weighted kappa: nominal scale agreement with provision for scaled disagreement or partial credit. Psychologi-1 cal Bulletin, 84. 1970 .

Collaris, J.W.M.

Bij kleinste hulsartspraktijken gemiddeld hoogste verwijsciffer. Inzet, $3,19-20,1980$.

Cottaar, M.; Doorn, H. van et a1.

Röntgenonderzoek in de huisartspraktijk. Hulsarts en Wetenschap, $26 \quad 373-375,1983$.

Crebolder, H.F.J.M.

onderzoekingen rond het gezondheidscentrum Withuls. Huisarts en Wetenschap, 20, 43-52, 1977 .

Deen, K.J., van

Arbeidsanalyse in een plattelandspraktijk. Groningen, dissertatie, 1952 . 
Dool, C.W.A., van den

Survelliance van risicogroepen; anticiperende geneeskunde. Hulsarts en Wetenschap, 13, 59-62, 1970.

Dophelde, J.P.

Verwljzingen door de huisarts. Gezondheid en Samenleving, 3, 141-151, 1982 .

Duuren, R., van; Hupkens, L.A.J.

Verschillen in verwijsgedrag doar samenwerkingsverband. Medisch Contact, 36, 1933-1936, 1981. Elting, $W$.

De analyse van én dag praktijkvoering; een explorerend onderzoek van de spreekuurgesprekken. Huisarts en Wetenschap, 15, 259-269, 1972 .

Everitt, B.

Cluster Analysis. Halsted Press, New York, 1974. Feen, J.A.E., van der

Hypertensie en huisarts; een uitdaging. Huisarts en Wetenschap, 18, 406-411, 1975. Feen, J.A.E., van der

Hypertensie een ultdaging aan de hulsarts. Rotterdam, dissertatie, 1977.

Gerritsma, J.G.M.; Smal, J.A.

De werkwijze van huisarts en internist, een vergelijkend onderzoek met behulp van een interactieve patiëntensimulatle. Utrecht, dissertatie, 1982. Gozin, L.

Consultation behaviour of familles with psychosocial problems in a general practice. General practice International, 4,171-179, 1980 .

Herbert. J.; Attridge, C.

A gulde for developers and users of observation systems and manua1s. American Educational Research Journal, $12,1-20,1975$.

Heyns, R.W.; Zander, A.F.

observation of group behavior. In Festinger, $\mathbb{L}$. Katz, D.(eds.): Research methods in the behavorial sclences. New York: Holt, Rinehart \& Winston, 381-417, 1966. Hildebrand, D.K.

prediction analysis of cross classification. Wiley and Sons, New York, 1977.

Hogerze11, H.H.W.

Resultaten in een hulsartspraktijk. Utrecht, dissertatie, 1954 . 
Holten-Vriesema, $J$. et al.

"Methodisch werken". Een algemene methode van hulpverlening voor de huisarts. Hulsarts en Wetenschap, 21 , $322-335,1978$.

Hornstra, $R$.

De sociale discussie in het geneeskundig handelen. Tijdschrift voor Sociale Geneeskunde, 4, 55, 1950. Hull, F.M.

The General Practitioners use of time. Gerieral Practice International, $12,37-43,1983$.

Huygen, F.J.A.

Paradigma"s voor de huisartsgeneeskunde. Hulisarts en Wetenschap, $21,447-450,1978$.

Huygen, F.J.A.

Huisarts en preventie. Congresrede. Hulsarts en Wetenschap, 18, 429-432, 1965 .

Huygen, F.J.A.

Geboorteregeling in de praktijk van de huisarts; een oriënterend onderzoek. Huisarts en Wetenschap, 11 , $2-10,1968$.

Huygen, F.J.A.

Huisarts en revalidatie. Huisarts en Wetenschap, 13, $132-135,1970$.

Huygen, F.J.A.

De rol van de hulsarts als gezinsarts. Hulsarts en Wetenschap, $24,130-134,1981$.

Huygen, F.J.A.

Hulsarts, hoe sta je er voor? Huisarts en Wetenschap, $24,412-414,1981$.

Jacobs, H.M.; Touw-Otten, F.W.; De Melker, R.A.

Taakopvatting en zlekenhulsbezoek. Hulsarts en Wetenschap, 22, 226-234, 1979.

Jansen-Emmer, E.M.

Bijdrage tot de kennls van het aandeel van de hutsarts in de geneeskundige verzorging van de Amsterdamse bevolking. Zeist, dissertatie, 1958.

Ker11nger, F.N.

Foundations of behavorial research. Holt, Rinekart and Winston, Londen, 1964.

Kerlinger, F.N.; Padhazur, E.J. Multiple regression in behavorial research. Holt, Rinekart and Winston, Londen, 1973. 
KNMG-commissie Eerate Echelon.

De plaats van de medicus in het eerste echelon. Medisch Contact, $31,141-164,1976$.

Knox, J.D.E.; Anderson, R.A. et al.

General Practitioners care of the eldery: Studie of aspects of workload. Journal of the Royal College of General Practitioners, 34, $194198,1984$.

Kooy, L.R.

De inhoud van de nascholing. Huisarts en Wetenschap, $25,62-67,1982$.

LambertB, H.

Een toekomstvisie uit 1964" De werkzaamheden in de hulsartspraktijk nu en in de toekomst. Huisarts en WeLHV . tenschap, 25,199-202,1982.

Blauwdruk Beleid Landelljke Hulsartsen Vereniging, 1975 .

LHV . LHV .

NLeuwe Blauwdruk, Medisch Contact, 32, 973-977, 1977.

Interimrapport van de Commissie Takenpakket, october 1976.

LHV .

De Taken van de Huisarts. Rapport van de Commissie Takenpakket der Landelijke Huisartsen Vereniging. Medisch Contact, 32, 765-789, 1977 .

LHV .

Concept-rapport Basis-Takenpakket van de Huisarts. Utrecht, 1982 .

LHV .

De functie-omschrijving van de huisarts. Medisch Contact, $36,1471-1476,1981$.

LHV .

Basis-Takenpakket van de huisarts. Bijlage bif Medisch Contact van 8 juli 1983.

Mc Gregor, R.M.

The work of a family doctor. Journal of the Royal Col-

lege of General Practit1oners, 23, 787-791, 1973.

Melker, R.A. de

Beterschap door beter beleid. Dekker en Van der Vegt, Nijmegen, 1975.

Melker, R.A. de

Een proefonderzoek naar de verwijsgewoonte van een 
groep hulsartsen. Huisarts en Wetenschap, 17, 289-294, 1974.

Melker, R.A. de

Ziekenhuispatiënt huisarts, huisgezin. N1jmegen, dissertatie, 1973.

Minlsterle van Binnenlandse Zaken

Indeling van Nederland in provincies nieuwe stij1. Februari 1977 .

Ministerle van Sociale Zaken en Volksgezondheid

Nota Volksgezondheid, 1966.

Ministerle van Volksgezondheld en Milieuhygiène

Structurnota Gezondheidszorg. Staatsultgeverif, Den Haag, 1974 .

Mo11 van Charante, A.W.

Van ziektegevoel tot klaaggedrag. Huisarts en Wetenschap, $21,17-20,1978$.

More11, D.C.; Gage, H.G. et al.

Patterns of demand in general practice. Journal of the Royal College of General Practitioners, 19, 331-342, 1970 .

NHG.

Methodisch werken. Huisarts en Wetenschap, 21, 322335,1978 .

NHG.

Hoe helpt de dokter? Rapport, Utrecht, 1975.

NHG.

Woudschotenrapport. Commissie Wetenschappelijk Onderzoek, 1959.

NHI.

Het vertrek uit de huisartspraktijk 1972-1975. Rapport van $\mathrm{P}$. Groenewegen en J. van der Zee. Hulsarts en Wetenschap, $20,525-526,1977$.

Nelson, E. et al.

A study of the validity of the task inventary method of job analysis. Medical Care, vol. XIII, 104-113, 1975.

Nie, H.N. et a1.

Statistical package for the soclal sclences. Second edition. Mc Graw Hi11, New York, 1975.

Oliemans, A.P.

Morbiditeit in de huisartspraktijk. Utrecht, dissertatie, 1969. 
OOBterhuis, H.W.

30 juni, een dag ult een huisartspraktijk. Hulsarts en Wetenschap, 15, 241-269, 1972 .

Philipsen, H.

Hulsarts en Wetenschap, of hoe wordt het "loeren en oudehoeren" vervangen door "glssen en missen" ook in de huisartsgeneeskunde. In Vercruysse E.V.W.; PhIIipsen, H.; Diederiks, J.P.M. en Van der Zee, J.: Huisarts en sociaal-wetenschappelijk onderzoek. NHI, Utrecht, 1973.

Posthuma, B.H.; Van der Zee, J.

Tussen eerste en tweede echelon I. Analyse van gemeentelijke verwijsciffers ult het Landelijk Informatie Systeem Zlekenfondsen. NHI, Utrecht, 1977.

Prins, A.

Drempelverlaging tot gebruik van laboratoriumfacil1telten door de huisarts. Huisarts en Wetenschap, 19, $252-254,1976$.

Raupp, J.L.M.

Over werkwijzen van hulsartsen. Helmond, dissertatie, 1971 .

Ree, J.W.van

Het Nijmeegs Interventieproject. Nijmegen, dissertatie, 1981 .

Reiss, A.J.

Systematic observation of natural social phenomena. In: Coster, H.L. (ed.): Second Handbook of Research on Teaching - Chicago, Rand McNa11y, pp. 38, 122-183, 1971 .

RIchardson, I.M.; Howle, J.G.R. et al.

A study of general practitioner consultations in North-east Scottland (Aberdeen). Journal of the Royal College of General Practitloners, 23, 132-142, 1973.

Rop, H.J.; Lamberts, H.; Wee1, C. Van

Hulsarts en verwijsgedrag. Hulsarts en Wetenschap, 22 $306-312,1979$.

Ruhe, H.A.M.

Een hulsartspraktijk in 1938 en 1954. Van Gorcum, Assen, 1957.

Rijntjes, A.G.; Bouhuys, P.A.J.; Mol, A. et al.

Praktisch medisch onderwijs in de huisartspraktijk. Medisch Contact, 38, 365-368, 1983. 
Saan, M.

over methoden ter bevordering van de efficiency in de praktijkvoering van de huisarts. Groningen, dissertatie, 1967 .

Sanders, J.A.H.

Psychische problemen post partum. Medisch Contact, 18, 569-571, 1984 .

Schade, E. en Wallig, C.

Microbiologische diagnostiek in de huisartspraktijk. Medisch Contact, 17, 539-540, 1984.

Schreuder, J.TH.R.

De bejaarde patiënt. Omnia Praescribendi gratia, 38, $1-29,1970$. Opgenomen in: 20 jaar geriatrie; een keuze uit het werk van Prof. Dr J. Schreuder. Red. L.A.Cahn e.a. Van Loghum Slaterus, Deventer, 1973.

Schwach, E.; Brecht, J.G.; Schwarz, F.W.

Wie handeln Haus- und Familienärzte? General Practice Internationa $1,12,162-167,1983$.

Seelen, A.; Dlederiks, J.P.M.; Van Zutphen, W.M. et al.

Identification of cardiovascular risk factors in general practice. Hulsarts en Wetenschap, 23, 325-331, 1980. (Wonca-u1tgave).

Smit, $P$.

Spoedgevallen in de huisartspraktijk. Groningen, dissertatie, 1974 .

Soeters, J.M.L.M.

Patiënt gezondheidszorg en langdurige zlekte. Maastricht, dissertatie, 1983.

Staveren, G. van

Taakopvatting en werkwijze bij huisartsen. Amsterdam, dissertatie, 1984.

Utrechts Universitair Hulsartsen Instituut.

Kenmerken van de huisarts, 1975.

Veder-Smit, $E$.

Schets van de Eerste Lijnsgezondheidszorg. Tweede Kamer, zitting 1979-1980, 16066, nr 1-2.

Veenman. S.A.M.

Training op basis van interactie analyse. T1lburg, Zwijsen, 1975 . 
Ven, W.P. van de; Nauta, F.A.

Inventarisatie van achtergronden van comsumptieverschillen tussen ziekenfonds- en particulierverzekerden. Gezondheid en Samenleving, 1, 224-254, 1980.

Verhoef, $E$.

Gebrulk van Gezondheidszorgvoorzleningen, Nijmegen, dissertatie, 1979 .

Vliet, R.C. van; Ven W.P. van de

Analyse van medische comsumptie en van verschillen tussen ziekenfonds en particulier verzekerden. COEPSrapport, Leiden, 1982 .

Vriea, M.J. de

Systeemtheorle en algemene ziekteleer. Medisch Contact, 34, 1585-1588 en 1621-1624, 1979.

Wee1, C. van

Anticiperende geneeskunde in de praktijk. Rotterdam, dissertatie, 1981 .

Welck, K.E.

Systemic observational methods. In: Handbook of social psychology, vol. II. by Lindzey, G; Aronson, E. (eds.) Reading, Mass. 1968.

Wielen, $Y_{*}$, van der

De huisiats en de doeltreffendheld van $z$ f $\mathrm{fn}$ aandee 1 in de gezondheidszorg. Van Gorcum, Assen, 1960 .

Willemse, P.M.A.

Geriatrische zorg in de huisartspraktijk. Medisch Contact, $22,667-670,1981$. Wilson, J.B.

Work-load in a rural practice over the pas eighteen years. The Lancet, $1,733-734,1982$.

Wishart, $D$.

Cluster user manual; third edition, Edinburgh University, 1978 .

Zee, H., van der

Data analyse. Een wegwijzer voor onderzoekers en gebruikers van onderzoek. Boom, Meppel, 1975. 
BIJLAGE 1: VERSCHILLEN IN TESTWAARNEMINGEN TUSSEN OBSERVATOREN ONDERLING EN IN VERGELIJKING MET DE ONDERZOEKER-OBSERVATOR, WEERGEGEVEN MET BEHULP VAN DE BIJBEHORENDE WAARDEN VAN $\chi^{2}$

$\begin{array}{llll}\text { test } 1 & \text { test } 2 & \text { test } 3 & \text { test } 4 \\ \text { freq. tijd } & \text { freq. tijd freq. tijd freq. tijd }\end{array}$

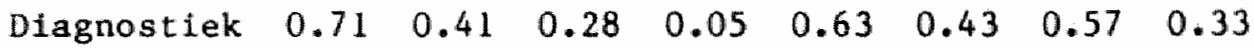

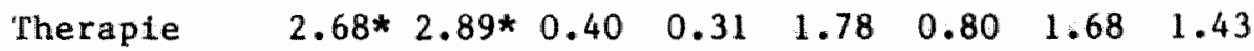

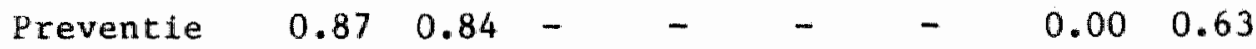

Begeleiding - $\quad \begin{array}{llllllll} & - & 0.01 & 0.75 & 0.01 & 0.46 & 0.00 & 0.14\end{array}$

Verwijzing - $\quad-\quad 0.01 \quad 0.37 \quad 0.00 \quad 0.00 \quad-$

Vrijheidsgraden

$\begin{array}{llll}7 & 7 & 6 & 6\end{array}$

$7 \quad 7$

78

8

Aantal consulten 5

15

/

6

$5 \quad /$

Totale tijd /

43
min.

$37 \quad /$

30

48

min.

min.

min.

(De waarden met * zijn significant op .05 niveau). 
Blflage 2: Vragenlijst, gebruikt bij "klelne" en "grote" steekproef.

Persoons- en praktifkgegevens van de hulsarts.

Hoe lang werkzaam in huldige prakti jk?

Grootte van praktijk per

1 Januar 1 1979:

- aantal ziekenfondspatiënten

- aantal particullere patiënten

Apotheekhoudend?

1. nee

2. ja

Pratkijkvorm:

1. solopraktijk

2. assoclatie

3. groepspraktijk

4. gezondheldscentrum

5. andere gestructureerde samenwerking $\mathrm{n} l$. gemiddeld aantal of percentage in

kleine grote steek- steek proef proef

$$
11.1^{\text {Jaren }} 10.5
$$

2041

2000

906

890

$\begin{array}{ll}67.7 & 71.5\end{array}$

$32.3 \quad 28.5$

62.4

67.1

19.4

19. 1

8.6

5.4

8.6

5.4

Indien er sprake is van gestructureerde samenwerking:

7.a. Met wie?

- andere arts(en) a potheker

- fystotherapeut

- maatschappelijk werker

- psycholoog(e)

- wijkverpleegkund 1 ge

- anderen, n1.
29.6

10.3

29.4

33.1

6.2

43.5

22.6

12.2

20.7

26.2

3.1

27.7

Heeft $u$ een vaste dienstregeling met uw (buurt) collegae? 
1. nee, door naar 9.

2. ja, door naar $8 a$.

8.a. Welke?

avond/nachtdienst

83

78.8

vacantie

82

82.7

weekenddienst door

naar $8 \mathrm{~b}$

95

96.6

Indien er een weekenddienst--

regeling is:

8.b. - hoe vaak? $1 \times$ per weken

- aantal patienten ....

9. Heeft $u$ hulppersoneel in uw praktijk?

- nee door naar 10. ja:

98.9

$94 \cdot 1$

- ja, door naar 9a.

9.a. Welke hulp?

- echtgenoot(e)

- dokters- of praktijkassistent(e)

$49 \cdot 5$

515

- apothekersassistent(e)

80.6

22.6

$68 \cdot 6$

- verpleger(ster)

$4 \cdot 3$

16.9

- medisch analist(e) of laborant(e)

$2 \cdot 2$

2.1

- administratieve assistentie

11.8

0.7

- assistent-arts

14.0

9.0

- andere nl.

6.5

8.6

3.9

10. Heeft u momenteel lemand in opleiding in uw praktijk?

- nee, door naar 11

- ja, door naar 10.a.

10.a. Wie?

- co-assistent(e)

7.5

5.4

- arts assistent(e)

18.3

13.2

- doktersassistent(e)

12.9

13.0

- overige, n1 : 
11. Wilt u door ankruisen aangeven over welke van onder staande instrumenten $u$ de beschikking heeft tijdens uw praktijkultoefening? ja:
- audiometer
- bloeddrukmeter
- brillendoos
- catheters
- electrocardiograaf
- electronische stethoscoop
- HB meter vgl. Sicca
- hechtset
- hydrecator
- kogeltang voor het plaatsen van een IUD
- Mayo intubatieset
- ophtalmoscoop
- peak-flow-meter
- polarimeter
- protoscoop
- rethoscoop (25 $30 \mathrm{~cm})$
- splegel voor indirecte laryngoscopie
- tonometer
- UKG-apparaat
- vaginaalspecula

18.3

23.3

100

99.7

21.5

23.0

94.6

93.6

30.1

20.8

4.3

6.8

73.1

71.8

97.8

95.3

65.6

58.0

48.4

43.6

36.6

33.2

90.3

87.9

33.3

27.9

3.2

4.2

54.8

8.6

54.1

5.0

58.1

$61 \cdot 6$

25.8

21.0

3.2

1.3

100

99.5

\section{Taakperceptie.}

Hierna volgen aan aantal pagina s met uitspraken over een aantal werkzaamheden van de hulsarts.

Deze uitspraken zifn geformuleerd als: "De huisarts moet ..." etc. Wilt u naar aanleiding van deze uitspraken telkens aangeven wat de Nederlandse huisarts met een volledige dagtaak naar uw mening behoort te doen en wat niet. U wordt verzocht niet uw huidige feltelljke werkzamheden aan te geven

Naast uw menling over wat de hulsarts behoort te doen, vragen wif ook naar uw mening over de mogelijkheden wat betreft gezondheldszorgvoorzieningen en tijd, die $u$ ter be schikking staan om de door u gewenste werkzaamheden te verrichten. Hierover hebben we per onderwerp telkens twee uit- 
spraken geformuleerd.

Na elke uitspraak staat een schaalverdeling van 1 tot 5 .

De cijfers hebben de volgende betekenis:

1 = mee eens

2 = enigszins mee eens

3 = neutraal of geen mening.

4 = enigszins mee oneens

5 = mee oneens

Wilt u tevens door omcirkeling van cén clffer aangeven in hoeverre $u$ het eens of oneens bent met de betreffende uit spraak.

N.B.: Het gaat voornamelijk om uw eerste indruk van een uitspraak. Het is dan ook van belang dat u niet te lang bij een bepaalde uitspraak blijft stilstaan.

\begin{tabular}{|c|c|}
\hline $\begin{array}{l}\text { kleine } \\
\text { steek- } \\
\text { proef } \\
\text { (percentag } \\
\text { "mee eeng" }\end{array}$ & $\begin{array}{l}\text { grot } \\
\text { stee } \\
\text { proe } \\
\text { i) }\end{array}$ \\
\hline
\end{tabular}

12. Diagnostiek.

1. Het analyseren van sociale problemen van $z i j n$ patiënten behoort tot de taak van de huisarts 79.3 80.8

2. De huisarts moet trachten van alle klachten die zijn patiënten hem voorleggen, zelf de oorzaken te achterhalen.

3. De huisarts moet in zijn diagnose niet alleen anamnestische onderzoeksgegevens betrekken, maar tevens het gedrag van de patiënt en zijn eigen reactle daarop.

4. De huisarts moet zijn patiënten duidelijk maken, dat hij zich in hoofdzaak met hun lichamelijke welbevinden bezighoudt. $72.8 \quad 70.1$ 
5. De voornaamste taak van de huisarts is vast te stellen door wie zijn patient op de meest adequate wijze kan worden behandeld.

6. De hulsarts dient meer aandacht te besteden aan dlagnostiek dan aan enige andere taak.

7. Ik vind de voorzleningen in mijn omgewing ter ondersteuning van de door mij gewenste dlagnostiek voldoende.

8. Naar mijn mening kan mijn dlagnostiek door tijdgebrek vaak nlet zo uitgebreid zijn als $i k$ wel zou willen.

13. Therapie.

1. De huisarts moet proberen zijn patienten zo veel mogelijk zelf te behandelen in plaats van doorverwijzen. $78.3 \quad 81.6$

2. Gesprekstherapie moet tegenwoordig tot de noodzakelijke vaardigheden van de huisarts behoren.

3. De hulsarts moet in zijn therapeutisch handelen zoveel mogelijk voorop stellen dat de patient zelf verantwoordelifk is voor het herstel van zljn gezondheid.

4. De huisarts $1 \mathrm{~s}$ de eerste aangewezene om een fysiologlsche partus te leiden.

5. Wanneer de patiënt een be handeling vraagt die de hulsarts nilet zinvol acht, moet hif deze toch verstrekken. 
6. Bij minder dan tien beva1lingen per jaar is het onverantwoord dat de huisarts zelf bevallingen leidt.

7. De huisarts dient meer kennis te hebben van de psychofarmaca dan van psychotherapie.

8. Ik vind dat de aanwezige gezondheidszorgvoorzieningen mij voldoende in staat stellen mijn patiënten de door mij gewenste behandeling te geven.

$62.0 \quad 73.8$

9. Naar mijn mening kom ik door tijdgebrek vaak niet toe aan door mij gewenste vormen van behandeling.

$42.9 \quad 41.3$

14. Begeleiding.

1. De huisarts moet beschouwd worden als de meest aangewezen persoon om stervens begeleiding te bieden. $80.6 \quad 78.6$

2. De begeleiding van highrisk groepen moet een van de meest belangrijke taken van de huisarts zijn.

3. De huisarts moet psychiatrische patiënten na hun ontslag uit een inrichting zelf begeleiding.

4. De hulsarts dient de begeleiding bij revalldatie van zijn patiënten in vrijwel alle gevallen zelf ult te voeren. $24.7 \quad 24.5$

5. Chronisch zieken dienen in overleg met de speclalist zoveel mogelijk door de huisarts behandeld te worden.

6. De hulsarts is meer geschilkt 
om de begeleiding van 11cht psychiatrische patiënten op zich te nemen dan de ambulante geestelijke gezondhetdszorg.

7. Ik vind dat $1 \mathrm{k}$ over voldoende spectifieke voorzleningen kan beschikken om mijn chronisch zieken een gepaste begeleiding te geven.

8. Naar mijn mening heb ik voldoende tijd om chronisch zieken uit mijn praktijk de door mij noodzakelijk geachte begeleiding te geven.

$58 \cdot 1$

67.2

15. Prevent1e.

1. De individuele primaire preventie moet tot het specifleke terrein van de hulsarts worden gerekend.

2. In ledere hulsartspraktijk zou door de huisarts periodiek screeningsonder zoek moeten worden yerricht bij high risk groepen. $39.1 \quad 40.8$

3. De huisarts behoort zijn patienten op te voeden tot een selectlever gebruik van de medische voorzieningen. $91.3 \quad 88.3$

4. De huisarts moet zich vanuit zijn werk ook met sociale en politieke problemen bemoelen.

5. De matschappelijke gezondheldszorg moet het merendeel van de primalre preventietaken van de hulsarts overnemen. 25.6

6. Vroege opsporing behoort meer tot de taken van de maatschappelfjke gezond- 
heldszorg dan tot de taken van de huisarts.

7. Het signaleren van maatschappelijke problemen als mogelijke pathogene factoren moet bij uitstek tot de taak van de huisarts gerekend worden.

8. Ik vind dat er in $m i j n$ omgeving voldoende faciliteiten zijn om de door mij gewenste preventie mogelijk te maken.

9. Naar mijn mening heb ik voldoende tijd om de door mij gewenste vormen van preventie toe te passen. 42.4 $42 \cdot 6$

16. Verwijzing binnen de gezondheidszorg.

1. Hulsartsen moeten gericht naar superspecialisten kunnen verwijzen. $79.1 \quad 86.0$

2. Huisartsen zouden door specialisten veel intensiever bij de behandeling van door hen verwezen patiënten betrokken moeten worden. 80.4 81.9

3. In de overwegingen over al dan niet verwijzen van een patiënt dient de huisarts ook de stifgende kosten van de gezondheidszorg te betrekken. $77.2 \quad 71 \cdot 2$

4. De huisarts behoort na een therapeutische verwijzing verantwoordelijkheid voor zijn patiënt te blijven dragen. $77.2 \quad 70.5$

5. Als de patiënt graag verwezen wil worden ter extra geruststelling dient een huisarts hiermee in te 
stemmen.

6. Ik vind dat Ik over voldoende moge 11 jkheden tot verwijzen beschik.

7. Nar mijn mening moet $1 k$ door t1jagebrek vaker verwiljzen dan ik eigenlijk zou willen.

17. Verwijzing buiten de gezondheidszorg.

1. Hulsartsen behoren patiênten indten nodig zo snel mogelijk door te sturen naar de sociale dienstverlening. 64.1 $61 \cdot 3$

2. De hulsarts moet de sociale problemen van $z 1 j n$ patiënten zelf aanpakken. 26.1 27.6

3. Wanneer de huisarts een patiënt doorstuurt naar de sociale dienstverlening is zijn verdere begeleiding niet meer noodzake $11 \mathrm{jk}$. $6.5 \quad 14.4$

4. Doordat de huisarts vaak als een soort ombudsman beschouwd wordt inzake soclale problemen, komt hij aan zijn eigen1ijke werk te welnig toe.

5. Het behoort tot de taak van de hutsarts om verantwoord advies over soclale voorzieningen te geven aan zijn patiënten. $50.0 \quad 50.2$

6. Ik vind dat er voldoende voorzleningen op het gebled van de sociale dienstverlening $z 1 j n$, warar $1 k$ mijn patiënten, indien nodig, naar kan doorsturen. $60.9 \quad 68.2$

7. Naar mijn mening kom ik 
ten gevolge van tijdgebrek onvoldoende toe an het geven van adviezen inzake sociale problemen.
27.2
24.5

18. Samenwerking met andere eerstelijns werkers.

1. Groepspraktijken en andere vormen van gestructureerd samenwerken tussen huisartsen betekenen een verlichting van ieders afzonderlljke taak.

2. Het klachtenaanbod van de patiënten maakt samenwerking van de huisarts met andere disciplines onont koombaar. $90.1 \quad 86.6$

3. De oorzaken van eventuele moeliijkheden bij samenwerking met andere disciplines moeten meer gezocht worden in mentaliteitsverschillen dan in practischorganisatorische omstandigheden.

$70.3 \quad 65.0$

4. Gestructureerd samenwerken met collegae-huisartsen moet beschouwd worden als een noodzakelifke voorwaarde voor een kwalltatief verantwoorde zorg. $69.7 \quad 59.4$

5. Binnen een samenwerkingsvorm waaraan ook andere disciplines deelnemen, blijft de huisarts de uitefindelijke verantwoordelijkheid dragen voor de medische beslissingen ten aanzien van zijn patiënten.

6. In een samenwerkingsverband met andere disciplines komt de specifieke taak van de huisarts beter tot zijn 
recht.

61.5

56.4

7. Verschillen in werktempo

en werkmethode tussen de huisarts en andere disciplines bemoeilijken de samenwerking in hoge mate. $63.7 \quad 57.2$

8. Kenmerkend voor een goede samenwerking met andere disciplines is het gezamen$11 j k$ dragen van de verantwoordelijkheld voor de welzijnszorg voor de patiënten. $76.9 \quad 75.0$

19. Taak-ondersteuning .

Wilt $u$ door telkens een cijfer te omcirkelen aangeven in welke mate u van onderstaande gezondheids- en welzijnszorgvoorzleningen gebruik maakt bij het vervullen van de vermelde taken. Wilt u daarna, eveneens door omcirkellng van een cijfer, aangeven in hoeverre de genoemde voorzieningen naar uw mening van nut $z i j n$ of kunnen $z i j n$ bij het vervullen van diverse gebruik

taken.

a. t.a.v. diagnostiek. percentage "geen"

1. Röntgenfaciliteiten KS GS

$21 \cdot 5$ 29.0 (mogelijk) $n$ u $t$ voor mammografie.

2. Afdeling van het centraal laboratorium van de bloedtransfusiedienst.

$\begin{array}{llll}51.6 & 58.8 & 37.6 & 30.5\end{array}$

3. Consultatlebureau voor TBC-bestrijding.

$\begin{array}{llll}34.4 & 33.3 & 8.6 & 14.1\end{array}$

4. Ambulante geestelijke gezondheidszorg.

$26.9 \quad 26.1 \quad 15.1 \quad 15.0$

5. Zlekenhuislab.

$\begin{array}{lllll}29.0 & 35.5 & 21.5 & 17.9\end{array}$

6. Huisartsenlab.

7. Algemeen maatschappelijk werk.

8. ecg-dienst. $\begin{array}{llll}33.8 & 30.6 & 30.1 & 11.6\end{array}$ Overige: 
b. T.a.v. medicamenteuze

therapie.

1. Stollingsiab.

2. (Geformaliseerd) overleg met ziekenhuisa po theker.

3. (Geformaliseerd) overleg met klinisch far macoloog.

4. (Geformaliseerd) overleg met gevestigd apotheker. overige:

c. T.a.v. therapeutische handelingen.

1. e.h.b.o. poll.

2. Fysiotherapeut.

3. Revalidatiearts.

4. Wijkverpleging.

5. Consultatiebureau voor geboorteregeling en sexualiteitsvragen.

6. Chirurgische poli. Overige:

d. T.a.v. therapeutisch gesprek.

1. Algemeen matschappelijk werk

2. Ambulante geestel1jke gebruik

percentage

"geen"

KS

31.2

$94 \cdot 6$

92.8

65.6

51.7

95.7

$94 \cdot 1$

54.8

43.6

45.2

40.3

24.7

14.2

(mogelljk)

nut

percentage "geen" 
gezondheidszorg.

3. Psychlater.

4. Psycholoog. over1ge e. T.a.v. advies.

1. Diêtist.

2. Schooladviesdienst.

3. Consultatlebureau voor geboorteregeling en sexualiteitsvragen.

4. Algemeen mat schappe-lijk werk.

5. Bureau voor medische sportkeuring.

6. Bedrijfsgeneeskundige dienst. overige:

f. T.a.v. begelelding van patiënten.

1. Algemeen maatschappe$11 j k$ werk.

2. Arnbulante geestelijke gezondheidszorg.

3. Consultatiebureau voor alcoholisme en drugs. 4. Schoolmaatschappelijk werk.

5. Klinisch psychiater.

6. Pastor. Overige:

$\begin{array}{rrrr}32.3 & 3.1 & 16.1 & 17.5 \\ 51.6 & 40.6 & 25.8 & 21.1 \\ 71.0 & 72.2 & 17.2 & 21.0\end{array}$

gebruik

(mogelijk)

nut

percentage

"geen"

percentage

"geen"

KS GS KS GS

$\begin{array}{llll}35.4 & 39.1 & 16.2 & 18.1\end{array}$

$\begin{array}{llll}71.0 & 74.0 & 30.1 & 27.4\end{array}$

$89.2 \quad 89.9 \quad 55.5 \quad 51.1$

$\begin{array}{llll}40.8 & 38.5 & 19.4 & 20.8\end{array}$

$\begin{array}{llll}81.7 & 76.9 & 43.0 & 54.5\end{array}$

$\begin{array}{llll}55.9 & 62.2 & 26.9 & 25.4\end{array}$

$\begin{array}{ll}\text { gebruik } & \text { (mogelijk) } \\ \text { nut } \\ \text { "gercentage } & \begin{array}{c}\text { percentage } \\ \text { "geen" }\end{array}\end{array}$

KS GS KS GS

$\begin{array}{llll}34.4 & 37.3 & 16.3 & 16.3\end{array}$

$38.7 \quad 40.4 \quad 16.2 \quad 18.6$

$\begin{array}{llll}51.6 & 55.8 & 19.4 & 24.0\end{array}$

$\begin{array}{llll}87.1 & 88.1 & 51.6 & 43.7\end{array}$

$\begin{array}{llll}61.3 & 49.1 & 30.1 & 22.0\end{array}$

$\begin{array}{llll}71.0 & 70.5 & 29.0 & 29.6\end{array}$

gebruik

(mogelijk)

nut 
g. T.a.v. preventie.

1. Consultatiebureau voor TBC-bestrijding .

2. Ziekenhuislab. voor huisartsen.

3. ecg-dienst.

4. G.G.\&G.D./districtsgeneeskundige dienst.

5. Bedrijfsgeneeskundige dienst.

6. Consultatiebureau voor zuigelingenzorg.

7. Schoolartsenzorg.

8. Consultatiebureau voor geboorteregeling en sexualiteitsvragen. percentage percentage
"geen" KS GS KS GS

$\begin{array}{llll}36.5 & 42.8 & 9.7 & 16.3\end{array}$

$\begin{array}{llll}34.4 & 27.8 & 20.4 & 14.5\end{array}$

$\begin{array}{llll}70.0 & 72.7 & 23.6 & 25.4\end{array}$

$\begin{array}{llll}77.4 & 70.8 & 37.6 & 38.7\end{array}$

$\begin{array}{llll}72.0 & 70.2 & 29.0 & 30.0\end{array}$

$\begin{array}{llll}18.7 & 18.0 & 11.8 & 8.6\end{array}$

$\begin{array}{llll}31.1 & 34.2 & 12.9 & 18.0\end{array}$

$80.6 \quad 87.3 \quad 51.6 \quad 51.0$

20 .

Wilt $u$, door telkens een cijfer te omcirkelen, aangeven op welk niveau - diagnostisch of therapeutisch - een hulsarts moet kunnen functioneren met betrekking tot aandoeningen, waarbij u ervan ult mag gaan, dat er geen acute of dringende indicaties bestaan voor spoedopname of spoedverwijzing.

a. Diagnostisch niveau.

KS GS

(percentage "mee eens")

1. Een huisarts behoort zelfstandig de diagnose cholelithiasis te kunnen stellen. $92.5 \quad 96.7$

2. Een huisarts moet eventuee 1 met behulp van een ecg-dienst, zelf cardiale ritmestoornissen kunnen differentiëren. $38.7 \quad 32.7$

3. Een huisarts dient ingeval van fertiliteitsklachten zelf een onderzoek naar de oorzaken bij beide partners in te kunnen stellen met behulp van gynaecologisch onderzoek, B.T.C. Sims-Hühnertest en semenanalyse. 
4. Een huisarts behoort met behulp van gedetallieerd onderzoek ontwikkelingsstoornissen bij kinderen

te kunnen vastgtellen.

$32.2 \quad 30.6$

5. Een huisarts dient ecg's te kunnen beoordelen.

6. Een hulsarts moet audiogrammen kunnen beoordelen.

7. Een hulsarts moet oogfundusonderzoek kunnen beoordelen.

8. Een hulsarts moet door middel van een punctie een haemarthros kunnen vastitellen.

20.426 .3

48.346 .5

61.370 .3

$63.4 \quad 67.7$

9. Een huisarts dient in staat te zijn een verhoogde oogboldruk te meten.

74.268 .5

b. Therapeutisch niveau.

KS

GS

(percentage "mee eens")

1. Een huisarts moet een paracentese kunnen doen.

$43.0 \quad 42.5$

2. Een huisarts behoort een wigexcisie bij een unguls incarnatus te kunnen uitvoeren.

$53.7 \quad 62.8$

3. De huisarts dient een patiënt met een acute urineretentie als gevolg van een prostaat-hypertrofie zelf te kunnen catheteriseren.

93.593 .5

4. Het aanmeten van een bril voor presbyople of lichte myople moet de hulsarts zelf kunnen doen. 26.926 .4

5. De hulsarts behoort een patiënt met een atopie zelf te kunnen desenstbiliseren. $64.5 \quad 52.5$

6. Gevallen van lichte tot matig ernstige rheumatolde arthritis moeten door de huisarts zelf behandeld kunnen worden. $82.8 \quad 80.3$

7. De huisarts dient een patiënt met een ulcus duodent zelf te kunnen behandelen. 
8. De behandeling van een patiënt

in een acute psychische crisis

toestand dient door de huisarts

gedaan te kunnen worden.

$50.5 \quad 55.4$

9. De huisarts dient een gravida

met een lichte zwangerschaps-

toxicose zelf te kunnen be-

handelen.

$75.3 \quad 75.2$

21.

Thans volgen er een aantal uitspraken over de verhouding arts-patiënt en over psychosociale klachten. Wilt $u$ door omcirkeling van een cijfer aangeven in hoeverre $u$ het met de uitspraak eens of oneens bent?

KS

GS

(percentage

"mee eens")

1. Een hulsarts moet altijd beschikbaar zijn voor zij patiënten.

$19.3 \quad 28.8$

2. Als de huisarts een patiënt medicijnen voorschrijft, dan dient hij de werking hiervan aan hem ult te leggen.

$86.0 \quad 85.6$

3. Patiënten moeten tegen hun huisarts op kunnen zien.

$13.1 \quad 16.7$

4. Gezien de psychische aard van bepaalde klachten waarmee patiënten bij hun huisarts komen, dient deze zich ook op dit terrein te bekwamen.

$87.9 \quad 87.8$

5. Hulsartsen zouden hun patiënten meer ult teg over hun zlektes moeten geven.

$74.2 \quad 80.8$

6. Met een afsprakenspreekuur is een hulsarts voldoende beschikbaar voor zijn patiënten. $60.2 \quad 61.6$

7. Het hoort tot de taak van de huisarts zijn patiënt met psychosoclale klachten de weg te wijzen in de matschappelijke dienstverlening.

8. Klachten van patiënten hebben 
vaak meer te betekenen dan opperviakig $11 j k t$.

$93.5 \quad 89.2$

9. Een succesvolle behandeling hangt

in hoge mate af van het feit of

de patient er het nut en de werking van inziet.

10. De huisarts behoort een natuur-

89.194 .1

$11 \mathrm{jk}$ overwicht te hebben over

zijn patiénten.

11. Een hulsarts zou patiënten meer

mogelijkheden moeten geven om

op afspraak builten het spreek-

uur bij hem langs te komen.

$48.4 \quad 46.2$

12. Het verlenen van hulp bij psycho-
sociale problemen gaat de compe-
tentie van de buren te boven.

12. Het verlenen van hulp bij psycho-
sociale problemen gaat de compe-
tentie van de buren te boven.

12. Het verlenen van hulp bij psycho-
sociale problemen gaat de compe-
tentie van de buren te boven.

$26.9 \quad 41.6$

13. Het contact van hulsarts en

$17.2 \quad 21.0$

patiẻnt is een contact van ge-

$11 \mathrm{jkwaardigen.}$

67.970 .9

14. Vakken als psychologie en

soclologle moeten een vaste

plaats krijgen in de opleiding

tot arts.

$79.5 \quad 77.0$

22 .

Thans volgt er een vraag naar uw mening over een aantal aspecten van uw werk. U wordt verzocht gebruik te maken van de schalwaarden $1-5$ zoals naast het criterium vermeld staan.

Mi jn werk als huisarts is:

1. Fascinerend.

KS

GS

(percentage

"mee eens")

2. Routinematig.

78.474 .8

3. Bevredigend.

$37.6 \quad 37.6$

4. Vervelend.

$84.9 \quad 87.6$

5. Goed.

3.26 .0

6. Creatief.

63.465 .0

7. Waardering schenkend.

$53.7 \quad 52.3$

8. Gejaagd.

$63.4 \quad 65.0$

9. Aangenaam.

$48.3 \quad 53.0$

$76.3 \quad 74.7$ 
10. Nuttig.

11. Vermoeiend.

$80.7 \quad 85.9$

12. Gezond.

$\begin{array}{ll}66.6 & 69.7\end{array}$

13. Uitdagend.

$29.0 \quad 23.3$

14. Veeleisend.

$76.3 \quad 74.5$

15. Frustrerend.

$84.9 \quad 87.6$

16. Eenvoudig.

$28.9 \quad 29.9$

17. Uitzichtloos.

$9.6 \quad 5.2$

18. Vruchtbaar.

$7.5 \quad 4.5$

$65.6 \quad 71.0$

De waarneming.

Grote steekproef

(percentage "eens")

23. Wilt $u$ aangeven in hoeverre $u$ het eens of oneens bent met de volgende uitspraken over het waarnemen.

- Meestal voel ik me tijdens de waarneming erg nerveus.

- Tijdens de waarneming sta $1 k$ erg onder druk.

- Na afloop van de waarneming ben ik geestelijk en lichamelijk volledig uitgeput. Waarnemen is buitengewoon vermoeiend.

24. Accepteert $u$ het dat de LHV zich actiever c.q. regulerender opstelt dan het geven van (zwaarwegende) adviezen, indien misstanden in waarnemingsregelingen worden geconstateerd?

1. ja

82.3

2. geen mening

9.5

3. nee

8.2

Nascholing.

25. Wilt u uw mening geven ten aanzien van de volgende uitspraak.

"eens"

Een hulsarts moet verplicht worden om een keer per jaar een georganlseerde cursorische nascholing te volgen.

26. De duur van een cursorische nascholing dient 
een aaneengesloten periode te bedragen van:

1. minder dan 2 dagen

2. 2 dagen

3. 3 tot 5 dagen

4. meer dan 5 dagen

27. Hoe moet naar uw mening een verplichte nascholling mogelijk gemaakt worden?

1. Door een waarnemingsregeling

"eens" binnen de elgen waarnemingsgroep.

76.2

2. Door een financiele tegemoetkoming in de kosten van een door de hulsarts zelf te zoeken waarnemer.

3. Centraal door het bureau waarnemingen van de LHV.

Toetsing.

28. Wilt u ten aanzien van de volgende uftspraken uw menling geven?

- ledere vorm van toetsing zal een

facultatief karakter moeten hebben.

"eens"

- De resultaten van een periodieke
toetsing moeten als voorwaarde gelden voor de registratie in het hulsartsregister.

- De toetsing dient zich voorname$11 \mathrm{jk}$ op het medisch handelen van de huisarts te richten.

- De arts-patiênt relatie moet het belangrijkste aspect van de toetsing $z i j n$.

- De praktijkorganisatie dient het belangrijkste aspect van de toetsing te zijn.

Medicatiebewaking .

29. Wilt u uw ming geven ten aanzien van de volgende ultspraak? 
Ter voorkoming van ongewenste interactie en overmatig gebruik van geneesmiddelen is een formeel geregelde vorm van medicatie-bewaking noodzakeli jk.

30. Een formeel geregelde vorm van medicatlebewaking dient opgedragen te worden aan: (slechts én antwoord aankruisen s.v.p.)

1. De huisarts

"eens"

2. De apotheker

32.4

3. De inspectile van de volksgezondheid 56.0 8.0

\section{Prescriptie.}

31. Wilt $u$ uw mening geven ten aanzien van de volgende uitspraken?

"eens"

- De Regeling en Klapper dient als verplichte norm ten aanzien van de prescriptie te worden ingevoerd.

- Een geformaliseerd overleg tussen huisarts en apotheker is noodzakelijk om de kwaliteit van de prescriptie te bewaken.

Vestigingsbeleid.

32. Denkt $u$ dat, indien de L.H.V. zelf geen regulering van vestigingsbeleld tot stand brengt, de overheid deze zaken ter hand za1 nemen?

1. ja

75.5

2. geen menling

12.8

3. nee

33. Accepteert u een verlaging van de rekennormprakt $1 j k$ (thans 2600) tot 2000?

1. ja

2. geen mening

3. nee

34. Accepteert $\mathrm{u}$ een maximering van de praktijkgrootte in verband met een vestigingsbeleid? (Maximering betekent hiler dat de hulsarts niet meer gehonoreerd wordt boven de rekennormprakt $1 j k+25 \%$ ). 
1. ja 69.7

2. geen mening

3. nee

35. Accepteert $u$ een maximum-percentage van 90\% van de bruto praktijkopbrengst in een jaar bij overdracht als goodwillbetaling?

1. ja

76.7

2. geen mening

10.3

3. nee

13.0

36. Acht $u$ een verplicht overdragen van nevenfunctles, en dus het openbaarmaken van verdiensten daarult, een aanvaardbaar instrument in het kader van een vestigingsbeleid?

1. Ja

35.5

2. geen mening

22.9

3 . nee

41.6 
Bijlage 3: Correlatiematrix (Pearson $r$ ) van de tijdsvariabelen.

$\begin{array}{llllll}1 & 2 & 3 & 4 & 5 & 6\end{array}$

1. anamnese

2. 1ich.onderzoek

3. eigen $1 \mathrm{ab}$. ond.

4. uitbest.lab.ond

5. uitbest.diagn.ond.

6. medicatie

7. advies

8. ther.handeling

9. gesprek

10. diagn-verwijzen

11. ther.verwijzen

12. consult vragen

13. consult geven

14. verw.bulten gez.zorg

15. inlichtingen vragen

16. inllchtingen geven

17. geboor teregeling

18. perinatale zorg

19. vaccinatie

20. periodiek gen.ond.

21. g.v.o.

22. survel11ance

23. chron cur beg.

24. follow up

25. informatie geven

26. praktifkorganisatie

27. admin./registr.

28. telefoon

29. a po theek

30. samenwerking

31. reistijd

32. soctaal contact

33. nascholing

34. onderwijs geven

35 . keuringen

36. categor begeleid.

37. privé

38. med.indicatieste11.
1.00

$.54 \quad 1.00$

.40

$--$

1.00

23

.33

.39

.24

.34

$-\cdots$

.28

$-.12$

.11

1.00

.54

.30

$\ldots$

.19

1.00

.42

.25

.20

$--$

1.00

.30

$--$

$-$

.16

.20

$-$

.26

$-.17$

$-\cdots$

$-$

$-$

$--$

$--$

$-$

.15

$--.16$

$-$

$-.16$

$--$

$-.16$

$---$

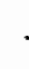

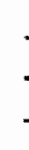

$--$

$-.18$

$-19$

$-$

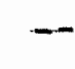$$
\text { (1) }
$$$$
\text { - }
$$

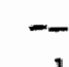

$-.17$

$-$

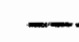

$-.2$

-

$-$

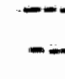

$-$

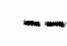

$-$

$\rightarrow-$

.17

.15

$-\cdots$

$-$

$-$

.30

$-$

$--$

.15

$-$

$-.17$

$--.17$

$-.18$

$-$

.18

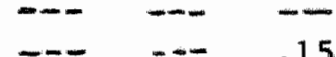

$--$

$-.29$

$-.27$

$-$

$-$

$-.20$

$-.24$

$-$

$-.24$

$-$

$-.20$

$-.42$

.1

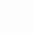

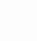

6


39. med.adv1seurschap

40. andere artsact.

41. bestuursact.

$$
\begin{array}{rr}
-.- & -.15 \\
-.16 & .20 \\
-.- & -.-
\end{array}
$$

7

7. advies

8. ther handeling

9. gesprek

10. dlagn.verwijzen

11. ther.verwijzen

12. consult vragen

13. consult geven

14. verw.buiten gez.zorg -.17

15. inlichtingen vragen

16. Inlichtingen geven

17. geboorterege1Ing

18. perinatale zorg

19. vaccinatie

20. perlodiek gen.ond.

21. g.v.o.

22. surveillance

23. chron-cur.begeleld.

24. follow-up

25. Informatie geven

26. praktijkorganisatie

27. admin./registr.

28. telefoon

29. a potheek

30. samenwerkfing

31. relstijd

32. soctaal contact

33. naschollng

34. onderwijs geven

35. keuringen

36. categor begeleld.

37. prive

38. med.indicatieste11.

39. med.adviseurschap

40. andere artsact.

41. bestuursact.
1.00

$.17 \quad 1.00$

$\begin{array}{r}- \\ -.20 \\ -.17 \\ .17 \\ -17 \\ \hline\end{array}$

$-50$

8

9

10

11

12

1.00

-. 1.00

1.00

$-m$

$-\cdots$

1.00

$-m-$

$-\infty$

1.00

$-.21$

$--$

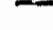

$-\mathbf{n}$

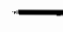

$-$

$-$

$-2$

$-\infty$

$-$

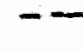

$--$

$-\overline{-17}$

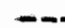

$-$

$-.17$

.19

$-$

$-.22$

$-.26$

.16

$--.21$

$-$

-

$-\cdots$

$-.20$

.31

$-$

$\cdots$

$--$

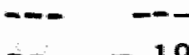

$-.19$

$-.28$

.15

-n -.. -

.21

-. -.15

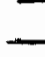

$-.23$

$-.16$

$-$

$-$

$-.16$

.38

$-.19$

$-$

$-$

$-$

$-\ldots$

$--\quad .17$

$-$

$-\quad-.16-.18$

$-$

$\cdots$

$-$

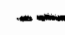

1

$-.26$

$-$

$-$

$-.16$

$-.22$

$-$

$-$

.39

.30

.22

-

.25

$-$

$-$

$-$

$-1$

$-.2$

$-$

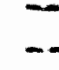

$-$

$-.19$

$-.22$

$-$

$-.25$

$-.15$

.33 
13. consult geven

14. verw.bulten gez.zorg

15. inlichtingen vragen

16. inlichtingen geven

17. geboorteregeling

18. perinatale zorg

19. vaccinatie

20. periodiek gen.ond.

21. g.v.o.

22. survel11ance

23. chron .cur begeleld.

24. follow-up

25. informatle geven

26. praktijkorganisatie

27 . admin./registr.

28. telefoon

29. apotheek

30. samenwerking

31. relstija

32. nascholing

34. onderwifs geven

35. keuringen

35. categor.begeleid.

37. prive

38. med.indicatieste1l.

39. med.adviseursch.

40. andere artsact.

41. bestuur sact.
13

1.00

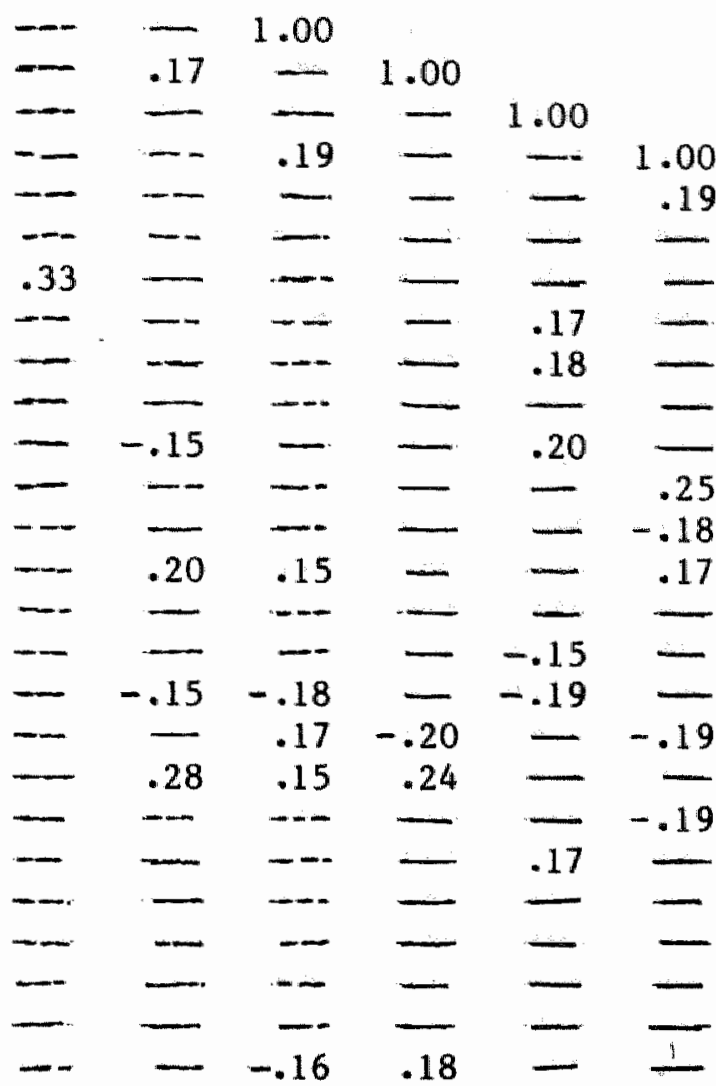

19. vaccinatie

19

20. perlodiek gen.ond.

21. g.v.o.

.37

20

21

22

23

24

1.00

$-16$

1.00

22. surve 11 lance

23. chron.cur begeleid.

.16

$-$

1.00

24. follow-up

25. Informatie gevan

- 1

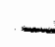

$-$

1.00

$\mp .21$

26. prakt1jkorganlsatie

27. admin./registr.

$-.19$

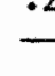

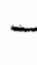
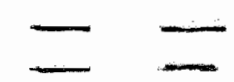

1.00 .18

28. telefoon

29. apotheek 
30. samenwerking

31. relst1jd

32. soclaal contact

33. nascholing

34. onderw1js geven

35. keurdngen

36. categor begeleid.

37. prive

38. med.indicatlestell.

39. med.adviseurschap

40. andere artsact.

41. bestuursact.

25. Informatie geven

26. praktifkorgan1satie

27. admin./reg1str.

28. telefoon

29. apotheek

30. samenwerking

31. reistijd

32. sociaal contact

33. nascholling

34 . onderw1js geven

35. keur1ngen

36. categor begeleid.

37. privé

38. med.Indicatiestell

40. andere artsact.

41. bestuursact.
39. med.adviseurschap

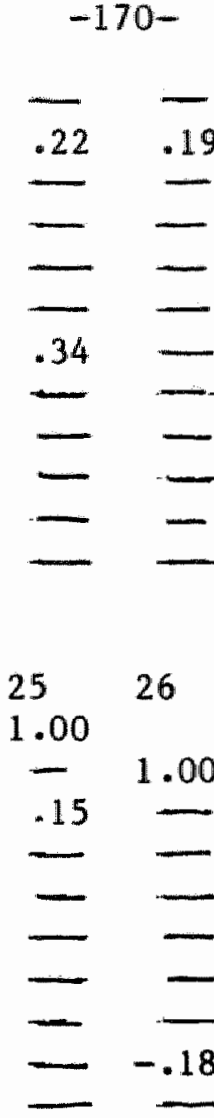

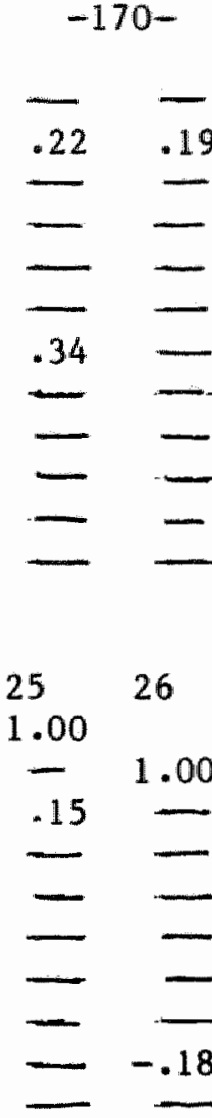

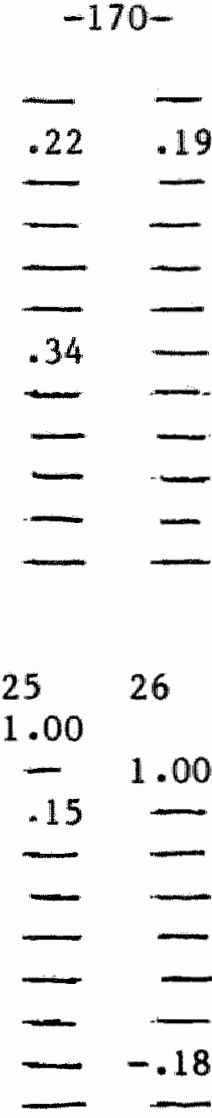

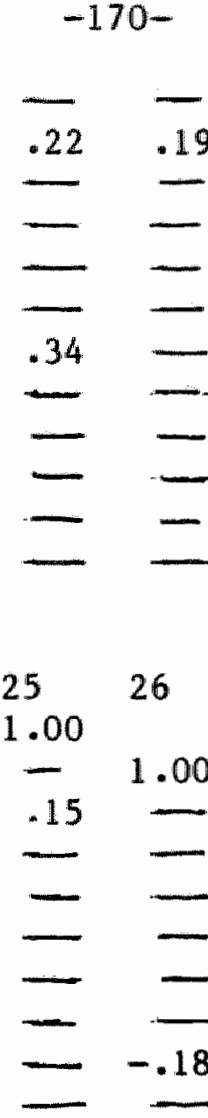
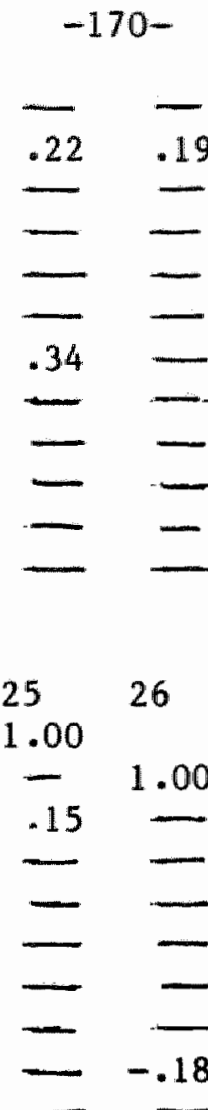

$=170-$
$= \pm=$
$= \pm$
$=34$
$=$
$=$
$=$
25
1.00
$=1.00$
$= \pm$
$= \pm$
$=-.18$

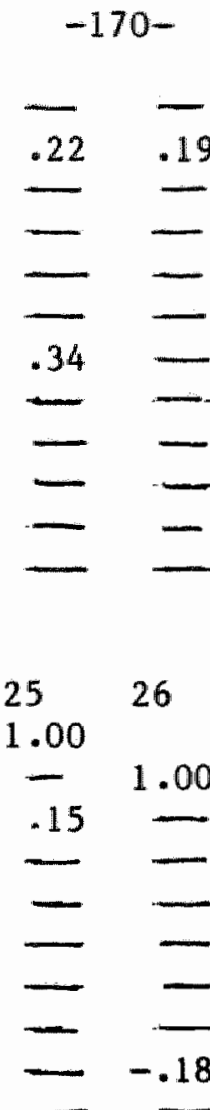

$=170-$
$= \pm=$
$= \pm$
$=34$
$=$
$=$
$=$
25
1.00
$=1.00$
$= \pm$
$= \pm$
$=-.18$
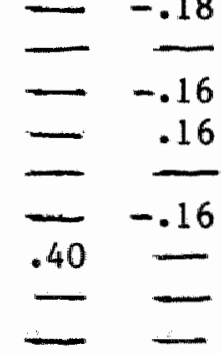

31

1.00

31. reist $1 j d$

32. soclaal contact

33. nascholing

34 . onderwijs geven

35 . keuringen

36. categor.begeleid.
.221 .00

$-\quad \begin{array}{r}1.00 \\ .18\end{array} \quad 1.00$

$-\quad .16-1.00$

- - -.17 1.00 
37. privé

38. med.indicatieste11.

39. med.adviseurschap

40. andere artsact.

41. bestuursact.

37. prive

38. med.indicatieste11.

39. med -adviseurschap

40. andere artsact.

41. bestuursact.

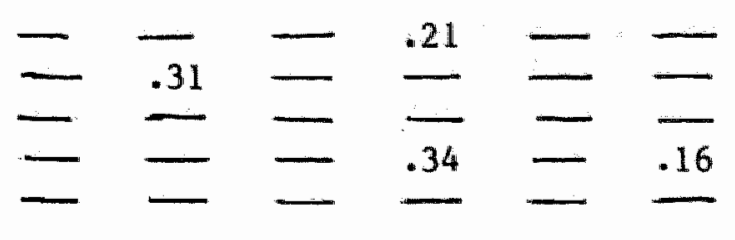

$\begin{array}{lllll}37 & 38 & 39 & 40 & 41\end{array}$

1.00

$-1.00$

$.19-1.00$

$-\quad-1.00$

$-\longrightarrow-$

1.00 
Bijlage 4: Frequentie-verdeling van de factorscores van de 91 huisartsen.

\begin{tabular}{lrrrrrr}
\hline & $F 1$ & $F 2$ & $F 3$ & $F 4$ & $F 5$ & $F 6$ \\
\hline 1.51 & 4 & 4 & 4 & 7 & 5 & 11 \\
$1.01-1.50$ & 9 & 6 & 4 & 6 & 10 & 8 \\
$.51-1.00$ & 14 & 13 & 15 & 9 & 10 & 11 \\
$.00-.50$ & 23 & 24 & 19 & 22 & 23 & 10 \\
$-.50-1.00--.51$ & 10 & 21 & 21 & 28 & 23 & 11 \\
$-1.50-1.01$ & 16 & 14 & 19 & 5 & 9 & 16 \\
$<-1.51$ & 11 & 5 & 8 & 10 & 4 & 8 \\
& 4 & 3 & 1 & 4 & 7 & 16 \\
\hline
\end{tabular}

De verdeling van de scores bij factor 6 beantwoordt niet aan de eisen van de normaal verdeling. Dit komt tot uiting in wat sterkere samenhangen in bijlage 5 .

B1jlage 5: Pearson $r$ correlaties tussen de zes "nileuwe" variabelen.

\begin{tabular}{|c|c|c|c|c|c|c|}
\hline & $\begin{array}{l}\text { cur. } \\
\text { zorg }\end{array}$ & $\begin{array}{l}\text { sam./ } \\
\text { ond. }\end{array}$ & $\begin{array}{l}\text { in } 1 . / \\
\text { ond. }\end{array}$ & $\begin{array}{l}\text { sec. } \\
\text { prev. }\end{array}$ & $\begin{array}{l}\text { prim. } \\
\text { prev. }\end{array}$ & $\begin{array}{l}\text { ge- } \\
\text { sprek }\end{array}$ \\
\hline cur. zorg & 1.00 & & & & & \\
\hline sam./ ond. & $\begin{array}{l}0.01 \\
S=.93\end{array}$ & 1.00 & & & & \\
\hline 1n1./nasch. & $\begin{array}{l}-.14 \\
S=.18\end{array}$ & $\begin{array}{l}-.02 \\
S=.86\end{array}$ & 1.00 & & & \\
\hline sec.prev. & $\begin{array}{c}12 \\
S=.25\end{array}$ & $\begin{array}{l}-.04 \\
S=.74\end{array}$ & $\begin{array}{l}-.26 \\
S=.01\end{array}$ & 1.00 & & \\
\hline prim.prev. & $\begin{array}{c}21 \\
S=.04\end{array}$ & $\begin{array}{c}.03 \\
S=.77\end{array}$ & $\begin{array}{c}.37 \\
S=.001\end{array}$ & $\begin{array}{c}.28 \\
S=.001\end{array}$ & 1.00 & \\
\hline gespreksv. & $\begin{array}{l}-.22 \\
S=.03\end{array}$ & $\begin{array}{c}.04 \\
S=.71\end{array}$ & $\begin{array}{l}-.34 \\
S=.001\end{array}$ & $\begin{array}{c}.40 \\
S=.001\end{array}$ & $\begin{array}{l}-.37 \\
S=.001\end{array}$ & 1.00 \\
\hline
\end{tabular}


Curriculum vitae.

De auteur van dit proefschrift werd geboren op 1 Januari 1940. Na de middelbare school gevolgd te hebben liet hif zich in 1960 inschrijven aan de Rijks Universitelt Utrecht voor de studie in de geneeskunde. Het doctoraalexamen werd in november 1965 behaald. Het arts-examen werd op 19 januari 1969 afgelegd.

Van 1963 tot 1965 heeft hij als student assistent gewerkt op het Instituut voor Histologie en Microscopische Anatomie van de R.U. te Utrecht onder leiding van Prof. Dr M.T.Jansen en Dr C.J. van den Broek.

In 1967 na het behalen van het semi-arts-examen, heeft hij nog zeven maanden gewerkt op het Pathologisch Anatomisch Instituut te Utrecht aan een klein onderzoek naar het ontstaan van granulomateuze ontstekingsreacties en de vorming van reuscellen onder leiding van Prof. Dr A. de Minjer.

Van januari 1969 tot november van dat zelfde jaar heeft de auteur een assistentschap vervuld in een huisartspraktijk In Amsterdam.

Op 15 november 1969 vestigde hij zich als hulsarts in T11burg

Op 1 september 1975 trad hij in dienst van de RIjks Universiteit Limburg bij de capaciteitsgroep Hulsartsgeneeskunde. Vanuit die functie heeft hij meegewerkt aan de tot standkoming van de volgende publicaties:

A.Seelen; J.Dlederiks; W. van Zutphen; B.Sikkens

Identification of cardiovascular risk factors in general practice Huisarts en Wetenschap, 23, 325331 , 1980. (WONCA-uitgave)

W.M. van Zutphen: The task perception of the genera1 practitioner. Free standing paper WoNCA congres, New Orleans. 1980 .

J.Boots en $W$. van Zutphen: Taakopvattingen van de hulsarts. Medisch Contact, $36,65-68,1981$.

J. van Reek; J.Dieder1ks; H.Ph111psen; W. van Zutphen; A.Seelen Subjective complaints and bloodpressure. J.Psychosom.Res., vol 26, 155165,1982 . 
A.G.RIjntjes; A.H.Mo1; W. van Zutphen: Patienten over studenten. De patiënt en het praktisch medisch onderwijs in de hulsartspraktijk. Medisch Contact, 39, $1025-1026,1984$. 